OPEN ACCESS

Edited by:

Katsuhiko Suzuki,

Waseda University, Japan

Reviewed by:

Waldemar Andrzejewski, University School of Physical

Education in Wrocław, Poland Yusuke Hara,

University of Tsukuba, Japan

${ }^{*}$ Correspondence: Aymeric Guillot

aymeric.guillot@univ-lyon1.fr

Specialty section:

This article was submitted to

Exercise Physiology,

a section of the journal

Frontiers in Physiology

Received: 28 August 2020 Accepted: 10 November 2020 Published: 21 December 2020

Citation:

Kerautret Y, Di Rienzo F Eyssautier $C$ and Guillot $A$ (2020) Selective Effects of Manual Massage and Foam Rolling on Perceived Recovery and Performance: Current Knowledge and Future Directions

Toward Robotic Massages.

Front. Physiol. 11:598898. doi: 10.3389/fphys.2020.598898

\section{Selective Effects of Manual Massage and Foam Rolling on Perceived Recovery and Performance: Current Knowledge and Future Directions Toward Robotic Massages}

\author{
Yann Kerautret ${ }^{1,2}$, Franck Di Rienzo ${ }^{1}$, Carole Eyssautier ${ }^{2}$ and Aymeric Guillot ${ }^{1 *}$ \\ 1 Univ Lyon, Université Claude Bernard Lyon 1, Laboratoire Interuniversitaire de Biologie de la Motricité EA 7424, \\ Villeurbanne Cedex, France, ${ }^{2}$ Capsix Robotics, Lyon, France
}

Manual massage and foam rolling are commonly used by athletes for warm-up and recovery, as well as by healthy individuals for well-being. Manual massage is an ancient practice requiring the intervention of an experienced physiotherapist, while foam rolling is a more recent self-administered technique. These two topics have been largely studied in isolation from each other. In the present review, we first provide a deep quantitative literature analysis to gather the beneficial effects of each technique through an integrative account, as well as their psychometric and neurophysiological evaluations. We then conceptually consider the motor control strategies induced by each type of massage. During manual massage, the person remains passive, lying on the massage table, and receives unanticipated manual pressure by the physiotherapist, hence resulting in a retroactive mode of action control with an ongoing central integration of proprioceptive feedback. In contrast, while performing foam rolling, the person directly exerts pressures through voluntary actions to manipulate the massaging tool, therefore through a predominant proactive mode of action control, where operations of forward and inverse modeling do not require sensory feedback. While these opposite modes of action do not seem to offer any compromise, we then discuss whether technological advances and collaborative robots might reconcile proactive and retroactive modes of action control during a massage, and offer new massage perspectives through a stochastic sensorimotor user experience. This transition faculty, from one mode of control to the other, might definitely represent an innovative conceptual approach in terms of human-machine interactions.

Keywords: physiotherapy, manual massage, self-myofascial release, cobots, foam rolling, robotic, motor control

\section{INTRODUCTION}

In the last decades, work and recreational activities drastically affected our habits by increasing sedentary life (Choi, 2019). This is further a well-admitted harmful consequence of the overuse of computers and smartphones resulting in various disorders such as postural deformity, and neck and shoulder pain (Choi, 2019). It is also well-established that the repetition and prolonged 
maintenance of body postures affects health (Kett and Sichting, 2020). To prevent and address such disorders, manual massage (MM) techniques are appreciated and recommended. However, these have not yet been considered as therapeutic interventions per se. Practically, MM target soft tissues such as muscles, tendons, and fascias (Guimberteau, 2004; Guimberteau et al., 2016). The MM treatment applied to these structures is performed through several maneuvers including effleurage, kneading, static or slide pressures, but also light and deep pressures. They are likely to involve biomechanical, physiological, neurological and psychological mechanisms, although these empirical attributions are not always confirmed by scientific data (Weerapong et al., 2005). While the benefits of MM are extensively demonstrated in the literature in individuals with or without motor disorders (Poppendieck et al., 2016), such interventions remain expensive and time-consuming (Weerapong et al., 2005). Delivering a MM requires a trained practitioner, and massaging interventions are difficult to scale since only one patient can be treated at the same time. To address these limitations, self-massage using foam-rolling (FR) became popular quite recently, especially in the sport domain. FR has applications in strength and conditioning, and is most frequently administered during warm-up and recovery. FR consists in making back and forth movements with a foam roller or a roller massager. FR thus consists in rolling actions applying pressure to soft tissues (Cheatham et al., 2015; Wiewelhove et al., 2019). Although direct comparisons between FR and MM in randomized control trials are limited (Sharp, 2012; Cho et al., 2015; Patole et al., 2019; Rivera et al., 2019), FR appears as conducive as $\mathrm{MM}$ to significantly improve performance (e.g., Schroeder and Best, 2015; Murray et al., 2016). Enhanced flexibility was observed in both athletes and non-athletes populations (Halperin et al., 2014; Kelly and Beardsley, 2016), and lower muscle pain was also reported after FR (Jay et al., 2014; Chan et al., 2015; Ceca et al., 2017). This accounted for an analgesic effect of FR, comparable to that found as a result of traditional MM (Monteiro et al., 2017b). Massaging techniques affect central pain-modulating sensory systems (nociceptors and mechanoreceptor sensitivity) (Capobianco et al., 2019). Also, mechanical pressure may alleviate pain perception through stimulation of afferent central nociceptive pathways and descending anti-nociceptive pathways, i.e., diffuse noxious inhibitory control (Wiewelhove et al., 2019). Both MM and FR might improve blood circulation and promote muscle homeostasis (i.e., rearrangements of myofascia, muscle fibers, and microvessels), although this claim awaits further experimental investigation (Schleip, 2003a,b).

As for $\mathrm{MM}$, evidence for the benefits of FR remains foremost empirical. In spite of accumulating research, in practice, the physiotherapist can modify the parameters according to the people based on his own feelings and experience to achieve the expected result. The physiotherapist can also benefit in real-time from feedback from his patient during the massage intervention. FR being a self-administration, each practitioner retains some degrees of adjustments of the different parameters, as found with MM. These two configurations make it possible to individualize the treatment but does not facilitate the establishment of practical guidelines. The purpose of this review was to highlight the similarities in terms of scientific research (e.g., population, uses, outcome measures and effects) on $\mathrm{MM}$ and $\mathrm{FR}$, and extend the discussion in the field of robotic massage. Currently, there is no literature review reporting the effects of these three massage modalities. The present paper first provides a synthesis of the experimental evidence supporting their benefits, and then disentangles optimal inherent characteristics and practical guidelines for efficient interventions. We also conceptualize the sensorimotor experience involved by $\mathrm{MM}$ and FR to delineate perspectives and research avenues. More specifically, we discuss whether MM should be considered a retroactive closed-loop convergence process while FR should rather be considered a proactive mode of action control. We consider to which extent future developments in the field, such as robotic solutions, might allow switching from a proactive to a retroactive mode of action control in specific massaging routines. We examine whether assisting classical massages with interactive and intelligent massaging robots might represent a promising and fruitful avenue.

This literature review was conducted using four search engines, Google Scholar, PubMeb, ResearchGate and Kinedoc, preceding and including 2020, without language restrictions. A total of 413 articles including key-words "foam roller," "roller massager," foam rolling," "self-myofascial release," "self-massage," "MM," "automated massage," and "robotic massage," were found in English, French and Spanish. A total of 316 articles were included. Items including the use of a foam roller or other comparative tool that did not include rolling the device on soft tissue were excluded (i.e., use for core stability training). A total of 173 articles were finally retained.

\section{MANUAL MASSAGE}

MM therapy is widely used as a warm-up method and cooldown process in sports (Weerapong et al., 2005). It is also administered in clinical populations for therapeutic purposes or well-being (Field et al., 2005). In the first case, therapeutic massage is practiced as part of therapeutic interventions targeting the symptoms of a specific pathology/disease. MM appears to be an effective treatment for infants of depressed mothers, and in elderly patients with severe dementia (Field et al., 1996; Suzuki et al., 2010). Also, world-class athletes benefit from MM to improve their performance and facilitate recovery (Espí-López et al., 2020). Noteworthy, the use of MM is not restricted to therapeutic or performance-enhancing interventions. Indeed, it is also used as a tool to promote well-being. Wellness massage is therefore not intended to treat patient, but also used for the sole purpose of enhancing perceived well-being across physical, mental, social and even spiritual domains (Andrade, 2013). The various maneuvers and pressures are performed on soft tissues by the hands of a qualified physiotherapist, who adjusts his MM routine based on the aim and time available for his intervention. 


\section{Dependent Variables}

\section{Psychometric and Behavioral Assessments}

$\mathrm{MM}$ is an ancestral practice found in many civilizations. Beyond these origins, it is available in three forms: wellness, therapeutic, and sports MM. To appreciate its impact, researchers first collected subjective evaluations through self-report ratings. These tools are simple to use, cost-effective, and non-invasive. While monitoring objective data is likely to provide greater levels of precision, it remains costly and invasive. There are nonetheless several reports of behavioral assessments of the effects of MMs. Joint amplitude is assessed by means of goniometers and functional tests (Leivadi et al., 1999; Hilbert et al., 2003; Zainuddin et al., 2005; McKechnie et al., 2007; Arabaci, 2008; Arazi et al., 2012; Iwamoto et al., 2016; Table 1). Behavioral measures also enabled researchers to assess the impact of MM on strength production of athletes (Rinder and Sutherland, 1995; Tiidus and Shoemaker, 1995; Farr et al., 2002; Hilbert et al., 2003; Dawson et al., 2004; Zainuddin et al., 2005; Jakeman et al., 2010). The influence of MM was also examined in vertical and horizontal power production (Farr et al., 2002; McKechnie et al., 2007; Willems et al., 2009; Jakeman et al., 2010; Delextrat et al., 2013; Abrantes et al., 2019). Speed and agility qualities were checked, taking into account acceleration, deceleration (Mancinelli et al., 2006; Arabaci, 2008; Arazi et al., 2012; Delextrat et al., 2013; Table 1).

\section{Neurophysiological Evaluations}

Technological advances allowed investigation of changes occurring at the physiological level (Table 2). For instance, cutaneous temperature attesting changes in peripheral blood circulation was frequently collected (Drust et al., 2003; Hinds et al., 2004; Mori et al., 2004). It thus became possible to evaluate muscle temperature (Drust et al., 2003; Hinds et al., 2004), speed of blood circulation (Tiidus and Shoemaker, 1995; Hinds et al., 2004; Mori et al., 2004; Wiltshire et al., 2010), and blood pressure (Hinds et al., 2004; Arroyo-Morales et al., 2008; Wiltshire et al., 2010; Table 2). Some researchers also investigated the repercussions of MM on the activation of the sympathetic and parasympathetic nervous systems through monitoring of heart rate variability (Hemmings et al., 2000; Drust et al., 2003; Robertson et al., 2004; Arroyo-Morales et al., 2008; Wiltshire et al., 2010; Pinar et al., 2012; Table 2). More invasive procedures, such as biopsies and blood sampling, enable measures of changes in cortisol levels, markers of inflammation and metabolic products (Kaada and Torsteinb, 1989; Smith et al., 1994; Leivadi et al., 1999; Hemmings et al., 2000; Hilbert et al., 2003; Hinds et al., 2004; Robertson et al., 2004; Zainuddin et al., 2005; Ogai et al., 2008; Cupido, 2010; Rapaport et al., 2010; Wiltshire et al., 2010; Crane et al., 2012; Pinar et al., 2012; Iwamoto et al., 2016; Kargarfard et al., 2016; White et al., 2020; Table 2). This represents valuable information to prevent stress or inflammatory conditions that may ultimately lead to injury or a state of overtraining.

\section{Short-Term Effects}

MM therapy has supposedly many virtues (Calvert, 2002). Its positive effects have been extensively reported in the scientific literature (Weerapong et al., 2005; Best et al., 2008; Brummitt, 2008). A sensation of psychological well-being was frequently reported (Mancinelli et al., 2006; Visconti et al., 2015). MM is further supposed to alleviate mood and anxiety disorders (Leivadi et al., 1999; Sharpe et al., 2007; Nakano et al., 2019), improve the feeling of recovery, reduce physical fatigue (Hemmings et al., 2000; Mori et al., 2004; Robertson et al., 2004; Ogai et al., 2008; Carcano et al., 2010; Pinar et al., 2012; Delextrat et al., 2013; Jourdain, 2015).

Several authors reported range of motion (ROM) gains. Indeed, the dorsiflexion following MM ranged from $18.4^{\circ}$ to $22.8^{\circ}$. Also, on a sit-and-reach box test, participants' score increased from 11.8 to $12.7 \mathrm{~cm}$, after only $15 \mathrm{~min}$ of $\mathrm{MM}$ (Arabaci, 2008; Iwamoto et al., 2016). More generally, MM were shown to induce short-term flexibility gains, similar to those induced by static stretching, without co-occurrence of negative effects on physical performance (McKechnie et al., 2007; Arazi et al., 2012). These notions of ROM and flexibility were combined to increase the suppleness of an athlete.

In terms of recovery, few studies measured the influence of manual therapy on muscle stiffness. To date, no consensus is clearly established. Authors observed, using a durometer, a drop in stiffness between two intense efforts after a kneading MM (Ogai et al., 2008). Ultrasound shear wave elastography also showed progress in stiffness, but the benefits did not last more than $3 \mathrm{~min}$ (Eriksson Crommert et al., 2015). Some contradictory results, obtained with a rotary potentiometer or a myotonometry device, could be due to the very short observation time (Thomson et al., 2015; Kong et al., 2018). Before drawing general conclusions, further experimental studies are certainly required. Particular attention should be paid to the timing of the measurements. Manual therapy further appears to be effective to reduce adverse effects of exercise, likely to elicit delayed-onset muscle damage (DOMS). These benefits were obtained when MM is performed immediately after the effort, and up to $3 \mathrm{~h}$ afterward; Table 3 ). A recent meta-analysis concluded that MM could be the most efficient post-exercise intervention to prompt recovery. Compared to cryotherapy, cold-water immersion and compression garment, MM elicited a greater reduction in DOMS, perceived fatigue, and markers of inflammation (Dupuy et al., 2018). With regards to sport performance, MM was punctually found to positively affect the recovery of muscle power (Mancinelli et al., 2006; Willems et al., 2009) Table 1). However, other studies failed to detect such positive changes (Tiidus and Shoemaker, 1995; Farr et al., 2002), while others reported negative effects (Arabaci, 2008; Arazi et al., 2012). Similar inconsistent results were also reported by various meta-analytical reviews (Brummitt, 2008; Gaullier, 2015; Poppendieck et al., 2016). In another set of studies, MM was not found to promote force reduction after an exercise-induced muscle damage (Tiidus and Shoemaker, 1995; Farr et al., 2002; Hilbert et al., 2003; Zainuddin et al., 2005; Table 3). Based on these data, and despite some inconsistencies, we shall recommend the use of MM before a physical effort or even between two successive sporting events. Also, athletes immobilized due to injury could benefit from MM. In mice, Saitou et al. (2018) demonstrated 
TABLE 1 | The effects of MM on performances.

\begin{tabular}{|c|c|c|c|c|c|c|c|c|c|}
\hline \multirow[t]{2}{*}{ Author (year) } & \multirow{2}{*}{$\begin{array}{l}\text { Study } \\
\text { design }\end{array}$} & \multirow[t]{2}{*}{ Sample } & \multicolumn{3}{|c|}{ Massage intervention } & \multirow[t]{2}{*}{ Control } & \multirow{2}{*}{$\begin{array}{l}\text { Others experimental } \\
\text { groups }\end{array}$} & \multirow{2}{*}{$\begin{array}{l}\text { Outcome } \\
\text { measures }\end{array}$} & \multirow[t]{2}{*}{ Effects } \\
\hline & & & Targeted area & Technique & $\begin{array}{l}\text { Treatment } \\
\text { time }\end{array}$ & & & & \\
\hline \multicolumn{10}{|l|}{ Range of motion } \\
\hline Leivadi et al. (1999) & $\mathrm{RCT}$ & 30 dance students & Whole body & $\begin{array}{l}\text { Effleurage, petrissage, } \\
\text { friction }\end{array}$ & $30 \mathrm{~min}$ & No & $\begin{array}{l}\text { Massage Relaxation } \\
\text { therapy } 2 \text { times/week } \\
\text { over } 5 \text { weeks }\end{array}$ & $\begin{array}{l}\text { Neck and shoulder } \\
\text { ROM }\end{array}$ & $\begin{array}{l}\text { Long term effect: } \\
\uparrow \text { neck extension ROM } \\
\uparrow \text { shoulder abduction } \\
\text { ROM }\end{array}$ \\
\hline Arazi et al. (2012) & $\mathrm{RCT}$ & 20 college athletes & $\begin{array}{l}\text { Main lower limb } \\
\text { muscles }\end{array}$ & $\begin{array}{l}\text { Effleurage, friction, } \\
\text { petrissage, vibration and } \\
\text { tapotment }\end{array}$ & $15 \mathrm{~min}$ & Yes & $\begin{array}{l}\text { Swiss massage } \\
\text { Static-stretching }\end{array}$ & Sit-and-reach & $\begin{array}{l}\uparrow \text { lower back and } \\
\text { hamstrings flexibility }\end{array}$ \\
\hline Hilbert et al. (2003) & $\mathrm{RCT}$ & $\begin{array}{l}18 \text { young and } \\
\text { healthy subjects }\end{array}$ & Hamstrings & $\begin{array}{l}\text { Effleurage, tapotement, } \\
\text { petrissage }\end{array}$ & $\begin{array}{l}20 \mathrm{~min} / \text { post } \\
2 \mathrm{~h}\end{array}$ & Yes & $\begin{array}{l}\text { Swedish massage } \\
\text { Placebo massage }\end{array}$ & $\begin{array}{l}\text { Straight leg raise } \\
\text { test }\end{array}$ & $\begin{array}{l}\text { NS change hamstring } \\
\text { ROM }\end{array}$ \\
\hline $\begin{array}{l}\text { McKechnie et al. } \\
\text { (2007) }\end{array}$ & $\mathrm{RC}$ & $\begin{array}{l}19 \text { healthy and } \\
\text { recreationaly active }\end{array}$ & Plantar flexors & Effleurage and petrissage & $3 \mathrm{~min} / \mathrm{leg}$ & Yes & $\begin{array}{l}\text { Petrissage } \\
\text { Tapotementat at } 4 \mathrm{~Hz}\end{array}$ & Ankle joint flexibility & $\begin{array}{l}\text { petrissage }> \\
\text { tapotement } \\
\uparrow \text { ankle ROM }\end{array}$ \\
\hline Arabaci (2008) & $\mathrm{RC}$ & $\begin{array}{l}24 \text { healthy and } \\
\text { physically active }\end{array}$ & $\begin{array}{l}\text { Main lower limb } \\
\text { muscles }\end{array}$ & $\begin{array}{l}\text { Effleurage, friction, } \\
\text { petrissage, vibration, } \\
\text { tapotment }\end{array}$ & $15 \mathrm{~min}$ & Yes & $\begin{array}{l}\text { Swedish massage } \\
\text { Stretching }\end{array}$ & Sit-and-reach & $\begin{array}{l}\uparrow \text { lower back and } \\
\text { hamstrings flexibility }\end{array}$ \\
\hline $\begin{array}{l}\text { Iwamoto et al. } \\
\text { (2016) }\end{array}$ & CT & 12 healthy students & Popliteal fossa & $\begin{array}{l}\text { Small circle with thumb at } \\
3 \mathrm{~Hz}\end{array}$ & $2-3 \min$ & No & Friction massage & Ankle joint flexibility & $\begin{array}{l}\uparrow \text { dorsiflexion } \\
\text { NS change plantar } \\
\text { flexion }\end{array}$ \\
\hline \multicolumn{10}{|c|}{ Power performance } \\
\hline $\begin{array}{l}\text { Mancinelli et al. } \\
(2006)\end{array}$ & $\mathrm{RCT}$ & $\begin{array}{l}22 \text { NCAA Division I } \\
\text { basketball and } \\
\text { volleyball players }\end{array}$ & $\begin{array}{l}\text { Quadriceps, } \\
\text { hamstrings }\end{array}$ & $\begin{array}{l}\text { Effleurage, petrissage and } \\
\text { vibration }\end{array}$ & $\begin{array}{l}17 \mathrm{~min} / \text { post } \\
48 \mathrm{~h}\end{array}$ & Yes & Western massage & $\begin{array}{l}\text { CMJ } \\
\text { Timed shuttle run }\end{array}$ & $\begin{array}{l}\uparrow \text { vertical power } \\
\text { NS change horizontal } \\
\text { power }\end{array}$ \\
\hline Arazi et al. (2012) & $\mathrm{RCT}$ & 20 college athletes & $\begin{array}{l}\text { Main lower limb } \\
\text { muscles }\end{array}$ & $\begin{array}{l}\text { Effleurage, friction, } \\
\text { petrissage, vibration and } \\
\text { tapotment }\end{array}$ & $15 \mathrm{~min}$ & Yes & $\begin{array}{l}\text { Swiss massage } \\
\text { Static-stretching }\end{array}$ & $\begin{array}{l}\text { Vertical jump, } 30 \mathrm{~m} \\
\text { sprint, agility-T test }\end{array}$ & $\begin{array}{l}\downarrow \text { horizontal and vertical } \\
\text { power } \\
\downarrow \text { agility }\end{array}$ \\
\hline $\begin{array}{l}\text { Delextrat et al. } \\
\text { (2013) }\end{array}$ & $\mathrm{RCT}$ & 8 bsketball players & $\begin{array}{l}\text { Main lower limb } \\
\text { muscles and back }\end{array}$ & Effleurage, petrissage & $15 \mathrm{~min} / \mathrm{leg}$ & Yes & $\begin{array}{l}\text { Massage Cold-water } \\
\text { immersion }\end{array}$ & $\begin{array}{l}\text { CMJ } \\
\text { Repeated sprint } \\
\text { ability }\end{array}$ & $\begin{array}{l}\uparrow \mathrm{CMJ} \\
\text { NS change repeated } \\
\text { sprint ability }\end{array}$ \\
\hline Farr et al. (2002) & $\mathrm{RCT}$ & $\begin{array}{l}8 \text { healthy and } \\
\text { recreationnaly } \\
\text { active }\end{array}$ & $\begin{array}{l}\text { Main lower limb } \\
\text { muscles }\end{array}$ & $\begin{array}{l}\text { Effleurage, petrissage (no } \\
\text { deep tissue massage) }\end{array}$ & $\begin{array}{l}30 \mathrm{~min} / \text { post } \\
2 \mathrm{~h}\end{array}$ & No & $\begin{array}{l}\text { Leg massage } \\
\text { Leg control }\end{array}$ & Single limb jumps & $\begin{array}{l}\downarrow \text { muscular power at } \\
24 \mathrm{~h}\end{array}$ \\
\hline $\begin{array}{l}\text { McKechnie et al. } \\
\text { (2007) }\end{array}$ & $\mathrm{RC}$ & $\begin{array}{l}19 \text { healthy and } \\
\text { recreationaly active }\end{array}$ & Plantar flexors & Effleurage and pettrisage & $3 \mathrm{~min} / \mathrm{leg}$ & Yes & $\begin{array}{l}\text { Petrissage } \\
\text { Tapotementat at } 4 \mathrm{~Hz}\end{array}$ & Drop-jump & $\begin{array}{l}\text { NS change muscular } \\
\text { power }\end{array}$ \\
\hline Arabaci (2008) & $\mathrm{RC}$ & $\begin{array}{l}24 \text { healthy and } \\
\text { physically active }\end{array}$ & $\begin{array}{l}\text { Main lower limb } \\
\text { muscles }\end{array}$ & $\begin{array}{l}\text { Effleurage, friction, } \\
\text { petrissage, vibration, } \\
\text { tapotment }\end{array}$ & $15 \mathrm{~min}$ & Yes & $\begin{array}{l}\text { Swedish massage } \\
\text { Stretching }\end{array}$ & $\begin{array}{l}30 \mathrm{~m} \text { sprint Leg } \\
\text { reaction time }\end{array}$ & $\begin{array}{l}\downarrow \text { horizontal and vertical } \\
\text { power } \\
\downarrow \text { reaction time }\end{array}$ \\
\hline
\end{tabular}


TABLE 1 | Continued

\begin{tabular}{|c|c|c|c|c|c|c|c|c|c|}
\hline \multirow[t]{2}{*}{ Author (year) } & \multirow{2}{*}{$\begin{array}{l}\text { Study } \\
\text { design }\end{array}$} & \multirow[t]{2}{*}{ Sample } & \multicolumn{3}{|c|}{ Massage intervention } & \multirow[t]{2}{*}{ Control } & \multirow{2}{*}{$\begin{array}{l}\text { Others experimental } \\
\text { groups }\end{array}$} & \multirow{2}{*}{$\begin{array}{l}\text { Outcome } \\
\text { measures }\end{array}$} & \multirow[t]{2}{*}{ Effects } \\
\hline & & & Targeted area & Technique & $\begin{array}{l}\text { Treatment } \\
\text { time }\end{array}$ & & & & \\
\hline $\begin{array}{l}\text { Jakeman et al. } \\
\text { (2010) }\end{array}$ & $\mathrm{RCT}$ & $\begin{array}{l}32 \text { healthy and } \\
\text { physically active }\end{array}$ & $\begin{array}{l}\text { Main lower limb } \\
\text { muscles }\end{array}$ & $\begin{array}{l}\text { Effleurage, petrissage, } \\
\text { tapotment and hacking }\end{array}$ & $30 \mathrm{~min}$ & Yes & $\begin{array}{l}\text { Sport massage }+ \\
\text { compression } \\
\text { Compression alone }(12 \mathrm{~h})\end{array}$ & $\begin{array}{l}\text { CMJ } \\
\text { Squat jump (SJ) }\end{array}$ & $\begin{array}{l}\uparrow \text { horizontal and vertical } \\
\text { power }\end{array}$ \\
\hline $\begin{array}{l}\text { Abrantes et al. } \\
\text { (2019) }\end{array}$ & $\mathrm{RCT}$ & $\begin{array}{l}39 \text { physically active } \\
\text { men }\end{array}$ & $\begin{array}{l}\text { Finger/elbow Stick } \\
\text { massage }\end{array}$ & $\begin{array}{l}\text { Main lower limb muscles } \\
\text { and chest }\end{array}$ & $8 \mathrm{~min}$ & No & $\begin{array}{l}\text { Manual massage (upper } \\
\text { body) + Foam rolling } \\
\text { (lower limbs) }\end{array}$ & $\begin{array}{l}\text { Vertical and } \\
\text { horizontal jump }\end{array}$ & $\begin{array}{l}\uparrow \text { vertical and horizontal } \\
\text { power }\end{array}$ \\
\hline \multicolumn{10}{|c|}{ Strength performance } \\
\hline $\begin{array}{l}\text { Rinder and } \\
\text { Sutherland (1995) }\end{array}$ & $\mathrm{RC}$ & 20 club member & Quadriceps & Effleurage and petrissage & $3 \mathrm{~min} / \mathrm{leg}$ & Yes & Massage & $\begin{array}{l}\text { Maximum number } \\
\text { of leg extension at } \\
50 \% 1 \mathrm{RM}\end{array}$ & $\begin{array}{l}\uparrow \text { quadriceps } \\
\text { performance }\end{array}$ \\
\hline $\begin{array}{l}\text { Tiidus and } \\
\text { Shoemaker (1995) }\end{array}$ & $\mathrm{RCT}$ & 9 healthy students & Quadriceps & $\begin{array}{l}\text { Superficial and deep } \\
\text { effleurage }\end{array}$ & $\begin{array}{l}10 \mathrm{~min} / \text { post } \\
<1 \mathrm{~h}\end{array}$ & No & $\begin{array}{l}\text { Leg massage } \\
\text { Leg control }\end{array}$ & $\begin{array}{l}\text { Isometric and } \\
\text { isokinetic knee } \\
\text { extension }\end{array}$ & $\begin{array}{l}\text { NS change muscle } \\
\text { strength }\end{array}$ \\
\hline $\begin{array}{l}\text { Zainuddin et al. } \\
\text { (2005) }\end{array}$ & $\mathrm{RC}$ & 10 healthy subjects & $\begin{array}{l}\text { Hand and main } \\
\text { upper limb muscles }\end{array}$ & $\begin{array}{l}\text { Effleurage, petrissage, } \\
\text { friction }\end{array}$ & $\begin{array}{l}10 \mathrm{~min} / \text { post } \\
3 \mathrm{~h}\end{array}$ & No & $\begin{array}{l}\text { Arm massage } \\
\text { Arm control }\end{array}$ & $\begin{array}{l}\text { Isometric and } \\
\text { isokinetic elbow } \\
\text { flexion }\end{array}$ & $\begin{array}{l}\text { NS change muscle } \\
\text { strength }\end{array}$ \\
\hline $\begin{array}{l}\text { Willems et al. } \\
\text { (2009) }\end{array}$ & $\mathrm{RCT}$ & $\begin{array}{l}7 \text { healthy and } \\
\text { moderately active }\end{array}$ & $\begin{array}{l}\text { Main lower limb } \\
\text { muscles }\end{array}$ & $\begin{array}{l}\text { Effleurage, petrissage, } \\
\text { tapotement }\end{array}$ & $25 \min$ & No & $\begin{array}{l}\text { Leg massage } \\
\text { Leg control }\end{array}$ & Single limb jumps & $\begin{array}{l}\uparrow \text { muscular power at } \\
48 \mathrm{~h}\end{array}$ \\
\hline $\begin{array}{l}\text { Jakeman et al. } \\
\text { (2010) }\end{array}$ & $\mathrm{RCT}$ & $\begin{array}{l}32 \text { healthy and } \\
\text { physically active }\end{array}$ & $\begin{array}{l}\text { Main lower limb } \\
\text { muscles }\end{array}$ & $\begin{array}{l}\text { Effleurage, petrissage, } \\
\text { tapotment and hacking }\end{array}$ & $30 \mathrm{~min}$ & Yes & $\begin{array}{l}\text { Sport massage }+ \\
\text { compression } \\
\text { Compression alone }(12 \mathrm{~h})\end{array}$ & Knee extension & $\begin{array}{l}\uparrow \text { isokinetic strength vs } \\
\text { control group }\end{array}$ \\
\hline $\begin{array}{l}\text { Abrantes et al. } \\
\text { (2019) }\end{array}$ & $\mathrm{RCT}$ & $\begin{array}{l}39 \text { physically active } \\
\text { men }\end{array}$ & $\begin{array}{l}\text { Finger/elbow Stick } \\
\text { massage }\end{array}$ & $\begin{array}{l}\text { Main lower limb muscles } \\
\text { and chest }\end{array}$ & $8 \mathrm{~min}$ & No & $\begin{array}{l}\text { Manual massage (upper } \\
\text { body) + Foam rolling } \\
\text { (lower limbs) }\end{array}$ & $\begin{array}{l}\text { Vertical and } \\
\text { horizontal jump }\end{array}$ & $\begin{array}{l}\uparrow \text { vertical and horizontal } \\
\text { power }\end{array}$ \\
\hline
\end{tabular}

$C T$, Clinical trial; RCT, randomized controlled trial; $R C$, randomized crossover; CCT, controlled clinical trial; NR, not reported; ROM, range of motion; CMJ, countermovement jump; $\uparrow$ indicates increase; $\downarrow$ indicates decrease; NS, not significant. 
TABLE 2 | The effects of MM on neurophysiological and psychological variables.

\begin{tabular}{|c|c|c|c|c|c|c|c|c|c|}
\hline \multirow[t]{2}{*}{ Author (year) } & \multirow{2}{*}{$\begin{array}{l}\text { Study } \\
\text { design }\end{array}$} & \multirow[t]{2}{*}{ Sample } & \multicolumn{3}{|c|}{ Massage intervention } & \multirow[t]{2}{*}{ Control } & \multirow{2}{*}{$\begin{array}{l}\text { Others experimental } \\
\text { groups }\end{array}$} & \multirow{2}{*}{$\begin{array}{l}\text { Outcome } \\
\text { measures }\end{array}$} & \multirow[t]{2}{*}{ Effects } \\
\hline & & & Targeted area & Technique & $\begin{array}{l}\text { Treatment } \\
\text { time and rate }\end{array}$ & & & & \\
\hline \multicolumn{10}{|c|}{ Neurophysiological and physiological effects } \\
\hline Leivadi et al. (1999) & $\mathrm{RCT}$ & 30 dance students & Whole body & $\begin{array}{l}\text { Effleurage, } \\
\text { petrissage, friction }\end{array}$ & $30 \mathrm{~min} / \mathrm{Slow}$ & No & $\begin{array}{l}\text { Massage Relaxation } \\
\text { therapy } 2 \text { times/week } \\
\text { over } 5 \text {-weeks }\end{array}$ & Salivary cortisol & $\downarrow$ cortisol (stress hormones) \\
\hline $\begin{array}{l}\text { Hemmings et al. } \\
\text { (2000) }\end{array}$ & $\mathrm{RCT}$ & 8 amateur boxers & $\begin{array}{l}\text { Main lower limb } \\
\text { muscles, back, } \\
\text { shoulder and arms }\end{array}$ & $\begin{array}{l}\text { Effleurage, } \\
\text { petrissage }\end{array}$ & $\begin{array}{l}20 \text { min } \\
\text { Effleurage: } \\
30 \text { strokes/min } \\
\text { Petrissage: } 50- \\
60 \text { strokes/min }\end{array}$ & Yes & Massage therapy & $\begin{array}{l}\text { Blood analyzes } \\
\text { Heart rate }\end{array}$ & $\begin{array}{l}\text { NS change blood lactate, } \\
\text { glucose concentration } \\
\text { NS change heart rate }\end{array}$ \\
\hline $\begin{array}{l}\text { Kargarfard et al. } \\
\text { (2016) }\end{array}$ & $\mathrm{RCT}$ & $\begin{array}{l}30 \text { male } \\
\text { bodybuilders }\end{array}$ & Quadriceps & $\begin{array}{l}\text { Effleurage, } \\
\text { petrissage and } \\
\text { vibration }\end{array}$ & $30 \mathrm{~min} /$ post $2 \mathrm{~h}$ & Yes & Western massage group & Blood sample & $\begin{array}{l}\text { Massage vs control group : } \\
\downarrow \text { creatine kinase level from } \\
48 \mathrm{~h} \text { up to } 72 \mathrm{~h}\end{array}$ \\
\hline White et al. (2020) & $\mathrm{RC}$ & $\begin{array}{l}9 \text { collegiate-level } \\
\text { athletes }\end{array}$ & $\begin{array}{l}\text { Main lower limb } \\
\text { muscles }\end{array}$ & $\begin{array}{l}\text { Effleurage and } \\
\text { neurolymphatic }\end{array}$ & $30 \mathrm{~min}$ & Yes & Massage therapy & $\begin{array}{l}\text { Blood sample } \\
\text { pre- and } \\
\text { post-exercise T0, } \\
\mathrm{T}+1,2 \mathrm{~h}, 24 \mathrm{~h}\end{array}$ & $\begin{array}{l}\downarrow \text { inflammation marker } \\
\text { concentrations }(\downarrow \Downarrow L-6)\end{array}$ \\
\hline $\begin{array}{l}\text { Kaada and } \\
\text { Torsteinb (1989) }\end{array}$ & CT & $\begin{array}{l}12 \text { subjects with } \\
\text { chronic pain }\end{array}$ & $\begin{array}{l}\text { Lumbo-sacral } \\
\text { region }\end{array}$ & $\begin{array}{l}\text { Connective tissue } \\
\text { massage }\end{array}$ & $30 \mathrm{~min} / \mathrm{Slow}$ & No & $\begin{array}{l}\text { Connective tissue } \\
\text { massage }\end{array}$ & Blood sample & $\begin{array}{l}\uparrow \text { relaxation substances } \\
\text { ( } \uparrow \text {-endorphins) }\end{array}$ \\
\hline Smith et al. (1994) & $\mathrm{RCT}$ & $\begin{array}{l}14 \text { healthy but } \\
\text { untrained subjects }\end{array}$ & Biceps, triceps & $\begin{array}{l}\text { Effleurage, shaking, } \\
\text { petrissage, } \\
\text { cross-fibre }\end{array}$ & $30 \mathrm{~min} /$ post $2 \mathrm{~h}$ & Yes & $\begin{array}{l}\text { Sport massage } \\
\text { Sham massage }\end{array}$ & Blood analyzes & $\begin{array}{l}\uparrow \text { neutrophils } \\
\downarrow \text { CK Less } \\
\downarrow \text { cortisol serum }\end{array}$ \\
\hline $\begin{array}{l}\text { Tiidus and } \\
\text { Shoemaker (1995) }\end{array}$ & $\mathrm{RCT}$ & 9 healthy students & Quadriceps & $\begin{array}{l}\text { Superficial and } \\
\text { deep effleurage }\end{array}$ & $\begin{array}{l}10 \mathrm{~min} / \text { post } \\
<1 \mathrm{~h}\end{array}$ & No & $\begin{array}{l}\text { Leg massage } \\
\text { Leg control }\end{array}$ & $\begin{array}{l}\text { Arterial blood } \\
\text { velocity } \\
\text { Venous blood } \\
\text { velocity }\end{array}$ & $\begin{array}{l}\text { NS change quadriceps } \\
\text { muscle blood flow }\end{array}$ \\
\hline Drust et al. (2003) & $\mathrm{RC}$ & 7 healthy subjects & Quadriceps & Deep effleurage & $\begin{array}{l}5,10,15 \mathrm{~min} \\
52 \text { strokes/min }\end{array}$ & No & $\begin{array}{l}3 \text { groups of massage } \\
\text { Ultrasound ( } 5 \mathrm{~min})\end{array}$ & $\begin{array}{l}\text { Heart rate monitor } \\
\text { Skin and } \\
\text { intramuscular } \\
\text { temperature }\end{array}$ & $\begin{array}{l}\uparrow \text { intra muscular and skin } \\
\text { temperature at depths of } \\
1.5 \text { and } 2.5 \mathrm{~cm} \\
\uparrow \text { heart rate }\end{array}$ \\
\hline Hilbert et al. (2003) & $\mathrm{RCT}$ & $\begin{array}{l}18 \text { young and } \\
\text { healthy subjects }\end{array}$ & Hamstrings & $\begin{array}{l}\text { Effleurage, } \\
\text { tapotement, } \\
\text { petrissage }\end{array}$ & $20 \mathrm{~min} /$ post $2 \mathrm{~h}$ & Yes & $\begin{array}{l}\text { Swedish massage } \\
\text { Placebo massage }\end{array}$ & Blood sample & NS change neutrophils \\
\hline
\end{tabular}


TABLE 2 | Continued

\begin{tabular}{|c|c|c|c|c|c|c|c|c|c|}
\hline \multirow[t]{2}{*}{ Author (year) } & \multirow{2}{*}{$\begin{array}{l}\text { Study } \\
\text { design }\end{array}$} & \multirow[t]{2}{*}{ Sample } & \multicolumn{3}{|c|}{ Massage intervention } & \multirow[t]{2}{*}{ Control } & \multirow{2}{*}{$\begin{array}{l}\text { Others experimental } \\
\text { groups }\end{array}$} & \multirow{2}{*}{$\begin{array}{l}\text { Outcome } \\
\text { measures }\end{array}$} & \multirow[t]{2}{*}{ Effects } \\
\hline & & & Targeted area & Technique & $\begin{array}{l}\text { Treatment } \\
\text { time and rate }\end{array}$ & & & & \\
\hline Hinds et al. (2004) & $\mathrm{RCT}$ & $\begin{array}{l}13 \text { yound healthy } \\
\text { subjects }\end{array}$ & Quadriceps & $\begin{array}{l}\text { Deep effleurage } \\
\text { and petrissage }\end{array}$ & $\begin{array}{l}2^{*} 6 \text { min } 50- \\
60 \text { strokes/min }\end{array}$ & Yes & Massage & $\begin{array}{l}\text { Blood flow } \\
\text { Skin and muscle } \\
\text { temperature } \\
\text { Blood sample } \\
\text { Blood pressure } \\
\text { Heart rate }\end{array}$ & $\begin{array}{l}\uparrow \text { skin temperature } \\
\uparrow \text { skin blood flow } \\
\text { NS change blood presusre, } \\
\text { heart rate, lactate } \\
\text { concentration and FABF }\end{array}$ \\
\hline $\begin{array}{l}\text { Robertson et al. } \\
\text { (2004) }\end{array}$ & $\mathrm{RC}$ & $\begin{array}{l}9 \text { healthy and } \\
\text { recreationnaly } \\
\text { active }\end{array}$ & $\begin{array}{l}\text { Main lower limb } \\
\text { muscles }\end{array}$ & $\begin{array}{l}\text { Effleurage, } \\
\text { kneading, picking } \\
\text { up, wringing, rolling }\end{array}$ & $\begin{array}{l}20 \mathrm{~min} / \text { post } \\
\text { active recovery } \\
5 \mathrm{~min}\end{array}$ & Yes & Massage & $\begin{array}{l}\text { Blood sample } \\
\text { Heart rate }\end{array}$ & $\begin{array}{l}\text { NS change lactate level and } \\
\text { heart rate response }\end{array}$ \\
\hline $\begin{array}{l}\text { Zainuddin et al. } \\
\text { (2005) }\end{array}$ & $\mathrm{RC}$ & 10 healthy subjects & $\begin{array}{l}\text { Hand and main } \\
\text { upper limb muscles }\end{array}$ & $\begin{array}{l}\text { Effleurage, } \\
\text { petrissage, friction }\end{array}$ & $10 \mathrm{~min} /$ post $3 \mathrm{~h}$ & No & $\begin{array}{l}\text { Arm massage } \\
\text { Arm control }\end{array}$ & $\begin{array}{l}\text { Upper arm } \\
\text { circumference } \\
\text { Blood sample }\end{array}$ & $\begin{array}{l}\downarrow \text { swelling } \\
\text { smaller } \uparrow \text { creatine kinase } \\
\text { activity }\end{array}$ \\
\hline $\begin{array}{l}\text { Arroyo-Morales } \\
\text { et al. (2008) }\end{array}$ & $\mathrm{RCT}$ & $\begin{array}{l}62 \text { healthy active } \\
\text { subjects }\end{array}$ & $\begin{array}{l}\text { Whole-body } \\
\text { myofascial release }\end{array}$ & $\begin{array}{l}\text { Long stroke, cross } \\
\text { hand, static } \\
\text { pressure }\end{array}$ & $\begin{array}{l}40 \mathrm{~min} / \text { post } 15 \\
\text { min active and } \\
\text { passive } \\
\text { recovery }\end{array}$ & Yes & $\begin{array}{l}\text { Sham (ultrasound and } \\
\text { magnetotherapy) }\end{array}$ & $\begin{array}{l}\text { Heart rate variability } \\
\text { Bood pressure }\end{array}$ & $\begin{array}{l}\downarrow \text { heart rate variability index } \\
\downarrow \text { diastolic blood pressure }\end{array}$ \\
\hline Ogai et al. (2008) & $\mathrm{RC}$ & $\begin{array}{l}11 \text { healthy and } \\
\text { active students }\end{array}$ & $\begin{array}{l}\text { Main lower limb } \\
\text { muscles }\end{array}$ & Petrissage & $\begin{array}{l}10 \text { min } \\
\text { between two } \\
\text { sets }\end{array}$ & Yes & Massage & Blood sample & $\begin{array}{l}\text { NS blood lactate } \\
\text { concentration }\end{array}$ \\
\hline Cupido (2010) & $\mathrm{RC}$ & $\begin{array}{l}13 \text { young healthy } \\
\text { and recreationnaly } \\
\text { active }\end{array}$ & Quadriceps & $\begin{array}{l}\text { Effleurage, } \\
\text { petrissage, } \\
\text { compression }\end{array}$ & $\begin{array}{l}10 \mathrm{~min} / \text { post } \\
10 \mathrm{~min}\end{array}$ & No & $\begin{array}{l}\text { Leg massage } \\
\text { Leg control }\end{array}$ & $\begin{array}{l}\text { Blood sample } \\
\text { Muscle damage } \\
\text { Muscle glucose } \\
\text { level }\end{array}$ & $\begin{array}{l}\text { NS glycogen, lactate } \\
\text { concentration and muscle } \\
\text { damage }\end{array}$ \\
\hline $\begin{array}{l}\text { Jakeman et al. } \\
\text { (2010) }\end{array}$ & $\mathrm{RCT}$ & $\begin{array}{l}32 \text { healthy and } \\
\text { physically active }\end{array}$ & $\begin{array}{l}\text { Main lower limb } \\
\text { muscles }\end{array}$ & $\begin{array}{l}\text { Effleurage, } \\
\text { petrissage, } \\
\text { tapotment and } \\
\text { hacking }\end{array}$ & $30 \mathrm{~min}$ & Yes & $\begin{array}{l}\text { Sport massage }+ \\
\text { compression } \\
\text { Compression alone }(12 \mathrm{~h})\end{array}$ & Blood sample & NS creatine kinase activity \\
\hline $\begin{array}{l}\text { Rapaport et al. } \\
\text { (2010) }\end{array}$ & $\mathrm{RCT}$ & 53 healthy subjects & Full body & $\begin{array}{l}\text { Effleurage, } \\
\text { petrissage, } \\
\text { kneading, } \\
\text { tapotement and } \\
\text { thumb friction }\end{array}$ & $45 \mathrm{~min}$ & No & $\begin{array}{l}\text { Swedish massage } \\
\text { Light touch }\end{array}$ & $\begin{array}{l}\text { Blood analyzes } \\
T+5,+1 \text { pre- } \min \\
\text { and post- } T+1,5 \text {, } \\
10,15,30,60 \text { min }\end{array}$ & $\begin{array}{l}\text { Massage }>\text { light touch } \\
\uparrow \text { immune system } \\
\text { ( } \uparrow \text { circulating phenotic } \\
\text { lymphocyte, } \downarrow \text { cytokine } \\
\text { level, arginine-vasopressin } \\
\text { and cortisol) }\end{array}$ \\
\hline
\end{tabular}


TABLE 2 | Continued

\begin{tabular}{|c|c|c|c|c|c|c|c|c|c|}
\hline \multirow[t]{2}{*}{ Author (year) } & \multirow{2}{*}{$\begin{array}{l}\text { Study } \\
\text { design }\end{array}$} & \multirow[t]{2}{*}{ Sample } & \multicolumn{3}{|c|}{ Massage intervention } & \multirow[t]{2}{*}{ Control } & \multirow{2}{*}{$\begin{array}{l}\text { Others experimental } \\
\text { groups }\end{array}$} & \multirow{2}{*}{$\begin{array}{l}\text { Outcome } \\
\text { measures }\end{array}$} & \multirow[t]{2}{*}{ Effects } \\
\hline & & & Targeted area & Technique & $\begin{array}{l}\text { Treatment } \\
\text { time and rate }\end{array}$ & & & & \\
\hline $\begin{array}{l}\text { Wiltshire et al. } \\
\text { (2010) }\end{array}$ & $\mathrm{RC}$ & 12 healthy subjects & Forearm muscles & $\begin{array}{l}\text { Effleurage, } \\
\text { petrissage }\end{array}$ & $10 \mathrm{~min}$ & Yes & $\begin{array}{l}\text { Massage } \\
\text { Active recovery }\end{array}$ & $\begin{array}{l}\text { Forearm blood flow } \\
\text { Blood sample } \\
\text { Heart rate }\end{array}$ & $\begin{array}{l}\downarrow \text { blood flow (impairing } \\
\text { lactic acid removal) } \\
\downarrow \text { heart rate vs active } \\
\text { recovery } \\
\text { NS change heart rate vs } \\
\text { passive recovery }\end{array}$ \\
\hline Crane et al. (2012) & $\mathrm{RCT}$ & $\begin{array}{l}11 \text { young healthy } \\
\text { and recreationnaly } \\
\text { active }\end{array}$ & Quadriceps & $\begin{array}{l}\text { Effleurage, } \\
\text { petrissage, } \\
\text { compression }\end{array}$ & $\begin{array}{l}10 \mathrm{~min} / \text { post } \\
10 \mathrm{~min}\end{array}$ & No & $\begin{array}{l}\text { Leg massage } \\
\text { Leg control }\end{array}$ & Blood analyzes & $\begin{array}{l}\downarrow \text { inflammation (cytokines } \\
\text { TNF-a, interleukin-6, heat } \\
\text { shock protein 27) } \\
\uparrow \text { mitochondrial biogenesis } \\
\text { (focal adhesion kinase, } \\
\text { ERK1/2, PGC-1a) } \\
\text { NS change muscle } \\
\text { metabolites (glyocgen, } \\
\text { lactate) }\end{array}$ \\
\hline Pinar et al. (2012) & $\mathrm{RC}$ & $\begin{array}{l}12 \text { young healthy } \\
\text { and recreationnaly } \\
\text { active }\end{array}$ & $\begin{array}{l}\text { Quadriceps, } \\
\text { hamstrings }\end{array}$ & $\begin{array}{l}\text { Effleurage, } \\
\text { kneading, picking } \\
\text { up, wringing, rolling }\end{array}$ & $24 \mathrm{~min}$ & Yes & $\begin{array}{l}\text { Massage } \\
\text { Electrical muscle } \\
\text { stimulation }\end{array}$ & $\begin{array}{l}\text { Blood sample } \\
\text { Heart rate }\end{array}$ & $\begin{array}{l}\text { NS blood lactate } \\
\text { concentration and heart } \\
\text { rate }\end{array}$ \\
\hline $\begin{array}{l}\text { Iwamoto et al. } \\
\text { (2016) }\end{array}$ & CT & 12 healthy students & Popliteal fossa & $\begin{array}{l}\text { Small circle with } \\
\text { thumb at } 3 \mathrm{~Hz}\end{array}$ & $2-3 \min$ & No & Friction massage & $\begin{array}{l}\text { Oxygenated } \\
\text { hemoglobin } \\
\text { Deoxygenated } \\
\text { hemoglobin } \\
\text { Total hemoglobin }\end{array}$ & $\begin{array}{l}\uparrow \text { venous return (muscle } \\
\text { oxygenation) }\end{array}$ \\
\hline \multicolumn{10}{|c|}{ Psychological effect } \\
\hline Leivadi et al. (1999) & $\mathrm{RCT}$ & 30 dance students & Whole body & $\begin{array}{l}\text { Effleurage, } \\
\text { petrissage, friction }\end{array}$ & $30 \mathrm{~min} / \mathrm{slow}$ & No & $\begin{array}{l}\text { Massage Relaxation } \\
\text { therapy } 2 \text { times/week } \\
\text { over } 5 \text { weeks }\end{array}$ & $\begin{array}{l}\text { State-trait anxiety } \\
\text { inventory } \\
\text { Profil of mood } \\
\text { states } \\
\text { Pain VAS-10 }\end{array}$ & $\begin{array}{l}\uparrow \text { mood } \\
\downarrow \text { anxiety } \\
\downarrow \text { pain }\end{array}$ \\
\hline $\begin{array}{l}\text { Hemmings et al. } \\
(2000)\end{array}$ & $\mathrm{RCT}$ & 8 amateur boxers & $\begin{array}{l}\text { Main lower limb } \\
\text { muscles, back, } \\
\text { shoulder and arms }\end{array}$ & $\begin{array}{l}\text { Effleurage, } \\
\text { petrissage }\end{array}$ & $\begin{array}{l}20 \text { min 30-60 } \\
\text { strokes/min }\end{array}$ & Yes & Massage & $\begin{array}{l}\text { Numerical recovery } \\
\text { scale }\end{array}$ & $\uparrow$ perceived recovery \\
\hline $\begin{array}{l}\text { Carcano et al. } \\
\text { (2010) }\end{array}$ & $\mathrm{CT}$ & $\begin{array}{l}96 \text { national and } \\
\text { international } \\
\text { atheletes }\end{array}$ & $\begin{array}{l}\text { Main lower limb } \\
\text { muscles }\end{array}$ & $\begin{array}{l}\text { Superifical and } \\
\text { deep effleurage, } \\
\text { friction }\end{array}$ & $\begin{array}{l}20-30 \\
\mathrm{~min} / \text { Slow }\end{array}$ & No & Swedish massage & $\begin{array}{l}\text { Pain VAS-10 } \\
\text { Fatigue VAS-10 } \\
\text { Well being VAS-10 }\end{array}$ & $\begin{array}{l}\downarrow \text { muscle soreness } \\
\downarrow \text { muscular fatigue } \\
\uparrow \text { well-being }\end{array}$ \\
\hline $\begin{array}{l}\text { Delextrat et al. } \\
\text { (2013) }\end{array}$ & $\mathrm{RCT}$ & 8 bsketball players & $\begin{array}{l}\text { Main lower limb } \\
\text { muscles and back }\end{array}$ & $\begin{array}{l}\text { Effleurage, } \\
\text { petrissage }\end{array}$ & $15 \mathrm{~min} / \mathrm{leg}$ & Yes & $\begin{array}{l}\text { Massage Cold-water } \\
\text { immersion }\end{array}$ & $\begin{array}{l}\text { Overall fatigue } \\
\text { VAS-10 }\end{array}$ & $\downarrow$ perceived fatigue \\
\hline
\end{tabular}


TABLE 2 | Continued

\begin{tabular}{|c|c|c|c|c|c|c|c|c|c|}
\hline \multirow[t]{2}{*}{ Author (year) } & \multirow{2}{*}{$\begin{array}{l}\text { Study } \\
\text { design }\end{array}$} & \multirow[t]{2}{*}{ Sample } & \multicolumn{3}{|c|}{ Massage intervention } & \multirow[t]{2}{*}{ Control } & \multirow{2}{*}{$\begin{array}{l}\text { Others experimental } \\
\text { groups }\end{array}$} & \multirow{2}{*}{$\begin{array}{l}\text { Outcome } \\
\text { measures }\end{array}$} & \multirow[t]{2}{*}{ Effects } \\
\hline & & & Targeted area & Technique & $\begin{array}{l}\text { Treatment } \\
\text { time and rate }\end{array}$ & & & & \\
\hline Jourdain (2015) & $\mathrm{CT}$ & 11 young athletes & $\begin{array}{l}\text { Main lower limb } \\
\text { muscles }\end{array}$ & $\begin{array}{l}\text { Longitudinal/ } \\
\text { transverse deep } \\
\text { sliding pressures, } \\
\text { kneading and } \\
\text { circular friction }\end{array}$ & $\begin{array}{l}10 \mathrm{~min} / \mathrm{leg} \text { post } \\
2 \mathrm{~h}\end{array}$ & No & $\begin{array}{l}\text { Massage } 1 \text { time/week } \\
\text { over } 5 \text {-weeks }\end{array}$ & HPHEES Scale & $\begin{array}{l}\downarrow \text { perceived fatigue on } \\
\text { waking NS change overall } \\
\text { physical form }\end{array}$ \\
\hline $\begin{array}{l}\text { Visconti et al. } \\
\text { (2015) }\end{array}$ & $\begin{array}{l}\text { Pilot } \\
\text { study }\end{array}$ & $\begin{array}{l}25 \text { ultramarathon } \\
\text { runners }\end{array}$ & $\begin{array}{l}\text { Main lower limb } \\
\text { muscles }\end{array}$ & Effleurage & $20 \mathrm{~min}$ & No & Massage & $\begin{array}{l}\text { Numeric pain rating } \\
\text { scale Patient global } \\
\text { impression of } \\
\text { change }\end{array}$ & $\downarrow$ muscle pain \\
\hline $\begin{array}{l}\text { Kargarfard et al. } \\
(2016)\end{array}$ & $\mathrm{RCT}$ & $\begin{array}{l}30 \text { male } \\
\text { bodybuilders }\end{array}$ & Quadriceps & $\begin{array}{l}\text { Effleurage, } \\
\text { petrissage and } \\
\text { vibration }\end{array}$ & $30 \mathrm{~min} /$ post $2 \mathrm{~h}$ & Yes & Western massage group & Pain VAS-10 & $\begin{array}{l}\downarrow \text { muscle soreness from } \\
24 \mathrm{~h} \text { up to } 72 \mathrm{~h}\end{array}$ \\
\hline Mori et al. (2004) & $\mathrm{RC}$ & 29 healthy students & $\begin{array}{l}\text { Lumbar and } \\
\text { sacrum region }\end{array}$ & $\begin{array}{l}\text { Effleurage, } \\
\text { kneading and } \\
\text { compression } \\
\text { techniques }\end{array}$ & $\begin{array}{l}5 \text { min between } \\
\text { two sets }\end{array}$ & Yes & Massage & Fatigue VAS-10 & $\downarrow$ perceived fatigue \\
\hline $\begin{array}{l}\text { Robertson et al. } \\
\text { (2004) }\end{array}$ & $\mathrm{RC}$ & $\begin{array}{l}9 \text { healthy and } \\
\text { recreationnaly } \\
\text { active }\end{array}$ & $\begin{array}{l}\text { Main lower limb } \\
\text { muscles }\end{array}$ & $\begin{array}{l}\text { Effleurage, } \\
\text { kneading, picking } \\
\text { up, wringing, rolling }\end{array}$ & $\begin{array}{l}20 \\
\text { min/post-active } \\
\text { recovery } 5 \text { min }\end{array}$ & Yes & Massage & Fatigue index & $\downarrow$ perceived fatigue \\
\hline Sharpe et al. (2007) & $\mathrm{RCT}$ & $\begin{array}{l}54 \text { elderly subjects } \\
\text { ( } \geq 60 \text { years) }\end{array}$ & Whole body & $\begin{array}{l}\text { Swedish, } \\
\text { neuromuscular, and } \\
\text { myofascial } \\
\text { techniques }\end{array}$ & $50 \mathrm{~min}$ & No & $\begin{array}{l}\text { Massage therapy Guided } \\
\text { relaxation } 2 \text { times/week } \\
\text { over 4-weeks }\end{array}$ & $\begin{array}{l}\text { General well-being } \\
\text { schedule Perceived } \\
\text { stress scale }\end{array}$ & $\begin{array}{l}\downarrow \text { anxiety, depression } \\
\uparrow \text { vitality, general health and } \\
\text { positive well-being vs } \\
\text { guided relaxation group }\end{array}$ \\
\hline Ogai et al. (2008) & $\mathrm{RC}$ & $\begin{array}{l}11 \text { healthy and } \\
\text { active students }\end{array}$ & $\begin{array}{l}\text { Main lower limb } \\
\text { muscles }\end{array}$ & Petrissage & $\begin{array}{l}10 \text { min } \\
\text { between two } \\
\text { sets }\end{array}$ & Yes & Massage & $\begin{array}{l}\text { Perceived fatigue } \\
\text { VAS-10 }\end{array}$ & $\begin{array}{l}\uparrow \text { perceived recovery } \\
\text { between two high intensive } \\
\text { exercises }\end{array}$ \\
\hline Pinar et al. (2012) & $\mathrm{RC}$ & $\begin{array}{l}12 \text { young healthy } \\
\text { and recreationnaly } \\
\text { active }\end{array}$ & $\begin{array}{l}\text { Quadriceps, } \\
\text { hamstrings }\end{array}$ & $\begin{array}{l}\text { Effleurage, } \\
\text { kneading, picking } \\
\text { up, wringing, rolling }\end{array}$ & $24 \mathrm{~min}$ & Yes & $\begin{array}{l}\text { Massage Electrical } \\
\text { muscle stimulation }\end{array}$ & $\begin{array}{l}\text { Total quality of } \\
\text { recoveryRating of } \\
\text { perceived exertion }\end{array}$ & $\begin{array}{l}\text { NS change psychological } \\
\text { recovery after high intensity } \\
\text { exercise }\end{array}$ \\
\hline $\begin{array}{l}\text { Nakano et al. } \\
\text { (2019) }\end{array}$ & $\mathrm{RC}$ & $\begin{array}{l}12 \text { elderly people } \\
\text { (65 years old) }\end{array}$ & HandsFeet & Stroke & $15 \mathrm{~min}$ & No & $\begin{array}{l}\text { Hand massage } \\
\text { Foot massage }\end{array}$ & Likert scale & $\begin{array}{l}\text { Both groups } \\
\uparrow \text { pleasant, relaxed and } \\
\text { refreshed feelings }\end{array}$ \\
\hline
\end{tabular}

CT, clinical trial; RCT, randomized controlled trial; RC, randomized crossover; VAS, visual analogue scale; NR, not reported; $\uparrow$ indicates increase; $\downarrow$ indicates decrease; NS, not significant. 
TABLE 3 | The effects of MM on delayed-onset muscle soreness.

\begin{tabular}{|c|c|c|c|c|c|c|c|c|c|c|}
\hline \multirow[t]{2}{*}{ Author (year) } & \multirow{2}{*}{$\begin{array}{l}\text { Study } \\
\text { design }\end{array}$} & \multirow[t]{2}{*}{ Sample } & \multicolumn{3}{|c|}{ Massage intervention } & \multirow{2}{*}{$\begin{array}{l}\text { Nature of the } \\
\text { exercise }\end{array}$} & \multirow[t]{2}{*}{ Control } & \multirow{2}{*}{$\begin{array}{l}\text { Others } \\
\text { experimental } \\
\text { groups }\end{array}$} & \multirow[t]{2}{*}{ Outcome measures } & \multirow[t]{2}{*}{ Effects } \\
\hline & & & Targeted area & Technique & $\begin{array}{l}\text { Treatment } \\
\text { time }\end{array}$ & & & & & \\
\hline $\begin{array}{l}\text { Mancinelli et al. } \\
\text { (2006) }\end{array}$ & RCT & $\begin{array}{l}22 \text { NCAA Division I } \\
\text { basketball and } \\
\text { volleyball players }\end{array}$ & Thigh & $\begin{array}{l}\text { Effleurage, } \\
\text { petrissage, } \\
\text { vibration }\end{array}$ & $\begin{array}{l}17 \mathrm{~min} / \text { post } \\
48 \mathrm{~h}\end{array}$ & $\begin{array}{l}\text { Intense strength } \\
\text { training and drills }\end{array}$ & Yes & $\begin{array}{l}\text { Western } \\
\text { massage }\end{array}$ & $\begin{array}{l}\text { PPT in quadriceps } \\
\text { femoris Muscle } \\
\text { soreness VAS-10 } \\
\text { Vertical jump }\end{array}$ & $\begin{array}{l}\downarrow \text { DOMS } \\
\uparrow \text { tenderness } \\
\uparrow \text { vertical power }\end{array}$ \\
\hline $\begin{array}{l}\text { Kargarfard et al. } \\
\text { (2018) }\end{array}$ & $\mathrm{RCT}$ & $\begin{array}{l}30 \text { male } \\
\text { bodybuilders }\end{array}$ & Quadriceps & $\begin{array}{l}\text { Effleurage, } \\
\text { petrissage and } \\
\text { vibratioon }\end{array}$ & $\begin{array}{l}30 \mathrm{~min} / \text { post } \\
2 \mathrm{~h}\end{array}$ & $\begin{array}{l}5 \text { sets of squat } \\
\text { until exhaustion } \\
\text { at } 75 \% \text { of } 1-R M\end{array}$ & Yes & $\begin{array}{l}\text { Western } \\
\text { massage }\end{array}$ & $\begin{array}{l}\text { Pain VAS-10 } \\
\text { CMJ } \\
\text { Blood sample } \\
\text { Isometric torque } \\
\text { pre- and post- TO, } \\
\mathrm{T}+24,48 \text { and } 72 \mathrm{~h}\end{array}$ & $\begin{array}{l}\text { Massage } \\
\downarrow \text { muscle soreness } \\
\text { at } 24,48 \text { and } 72 \mathrm{~h} \\
\downarrow \text { creatine kinase } \\
\text { from } 48 \mathrm{~h} \\
\uparrow \text { vertical power } \\
\text { and muscle } \\
\text { strength at } 48 \mathrm{~h}\end{array}$ \\
\hline Smith et al. (1994) & $\mathrm{RCT}$ & $\begin{array}{l}14 \text { healthy but } \\
\text { untrained subjects }\end{array}$ & Biceps, triceps & $\begin{array}{l}\text { Effleurage, shaking, } \\
\text { petrissage, } \\
\text { cross-fibre }\end{array}$ & $\begin{array}{l}30 \mathrm{~min} / \text { post } \\
2 \mathrm{~h}\end{array}$ & $\begin{array}{l}\text { Biceps and } \\
\text { triceps eccentric } \\
\text { exercise }\end{array}$ & Yes & $\begin{array}{l}\text { Sport massage } \\
\text { Sham massage }\end{array}$ & $\begin{array}{l}\text { Clarkson Scale } \\
\text { Blood creatine kinase } \\
\text { concentration } \\
\text { pre- and post- T0, T+8, } \\
24,48,72,96,120 \mathrm{~h} \\
\text { Bood analyses } \\
\text { (neutrophils and } \\
\text { cortisol) pre- and post- } \\
\text { T0, T+8 h (30-minute } \\
\text { intervals) }\end{array}$ & $\begin{array}{l}\downarrow \text { DOMS intensity } \\
\text { Peak DOMS at } 24 \mathrm{~h} \\
\downarrow \text { markers damage } \\
\text { and inflammation } \\
\text { (creatine kinase, } \\
\text { cortisol) } \\
\uparrow \text { neutrophils } \\
\text { activity }\end{array}$ \\
\hline $\begin{array}{l}\text { Tiidus and } \\
\text { Shoemaker (1995) }\end{array}$ & ССТ & 9 healthy students & Quadriceps & $\begin{array}{l}\text { Superficial and } \\
\text { deep effleurage }\end{array}$ & $\begin{array}{l}10 \mathrm{~min} / \text { post } \\
<1 \mathrm{~h}\end{array}$ & $\begin{array}{l}\text { Quadriceps } \\
\text { eccentric } \\
\text { exercises }\end{array}$ & No & $\begin{array}{l}\text { Leg massage } \\
\text { Leg control }\end{array}$ & $\begin{array}{l}\text { Numerical pain-rating } \\
\text { scale Isometric and } \\
\text { isokinetic knee } \\
\text { extension pre- and } \\
\text { post- } T+15 \mathrm{~min}, \mathrm{~T}+24 \text {, } \\
48,72,96 \mathrm{~h}\end{array}$ & $\begin{array}{l}\text { Tendency } \downarrow \\
\text { perception of } \\
\text { DOMS from } 48 \mathrm{~h} \\
\text { Peak DOMS at } 24 \mathrm{~h} \\
\text { NS change muscle } \\
\text { strength }\end{array}$ \\
\hline Farr et al. (2002) & RCT & $\begin{array}{l}8 \text { healthy and } \\
\text { recreationnaly } \\
\text { active }\end{array}$ & $\begin{array}{l}\text { Main lower limb } \\
\text { muscles }\end{array}$ & $\begin{array}{l}\text { Effleurage, } \\
\text { petrissage (no deep } \\
\text { tissue massage) }\end{array}$ & $\begin{array}{l}30 \mathrm{~min} / \text { post } \\
2 \mathrm{~h}\end{array}$ & $\begin{array}{l}40 \text { min downhill } \\
\text { treadmill walk } \\
\text { loaded }\end{array}$ & No & $\begin{array}{l}\text { Leg massage } \\
\text { Leg control }\end{array}$ & $\begin{array}{l}\text { Clarkson Scale } \\
\text { PPT } \\
\text { Isometric and isokinetic } \\
\text { knee extension } \\
\text { Vertical jump } \\
\text { pre- and post- T0, } \\
\text { T+24, } 48,72,96,120 \mathrm{~h}\end{array}$ & $\begin{array}{l}\text { Tendency } \downarrow \text { DOMS } \\
\text { magnitude } \\
\downarrow \text { muscle } \\
\text { tenderness } \\
\text { attenuate the } \\
\text { decrease of } \\
\text { strength and } \\
\text { vertical power }\end{array}$ \\
\hline
\end{tabular}


TABLE 3 | Continued

\begin{tabular}{|c|c|c|c|c|c|c|c|c|c|c|}
\hline \multirow[t]{2}{*}{ Author (year) } & \multirow{2}{*}{$\begin{array}{l}\text { Study } \\
\text { design }\end{array}$} & \multirow[t]{2}{*}{ Sample } & \multicolumn{3}{|c|}{ Massage intervention } & \multirow{2}{*}{$\begin{array}{l}\text { Nature of the } \\
\text { exercise }\end{array}$} & \multirow[t]{2}{*}{ Control } & \multirow{2}{*}{$\begin{array}{l}\text { Others } \\
\text { experimental } \\
\text { groups }\end{array}$} & \multirow[t]{2}{*}{ Outcome measures } & \multirow[t]{2}{*}{ Effects } \\
\hline & & & Targeted area & Technique & $\begin{array}{l}\text { Treatment } \\
\text { time }\end{array}$ & & & & & \\
\hline Hilbert et al. (2003) & $\mathrm{RCT}$ & $\begin{array}{l}18 \text { young and } \\
\text { healthy subjects }\end{array}$ & Hamstrings & $\begin{array}{l}\text { Effleurage, } \\
\text { tapotement, } \\
\text { petrissage }\end{array}$ & $\begin{array}{l}20 \mathrm{~min} / \text { post } \\
2 \mathrm{~h}\end{array}$ & $\begin{array}{l}\text { Hamstrings } \\
\text { eccentric } \\
\text { exercises }\end{array}$ & Yes & $\begin{array}{l}\text { Swedish } \\
\text { massage } \\
\text { Placebo } \\
\text { massage }\end{array}$ & $\begin{array}{l}\text { Differential descriptor } \\
\text { scale intensity of } \\
\text { soreness Blood sample } \\
\text { Eccentric hamstring } \\
\text { contraction pre- and } \\
\text { post- TO, } T+2,6,24 \text {, } \\
48 \mathrm{~h}\end{array}$ & $\begin{array}{l}\downarrow \text { perception of } \\
\text { DOMS from } 48 \mathrm{~h} \\
\text { Peak DOMS at } \\
24 \mathrm{~h} \text { NS change } \\
\text { neutrophils, ROM } \\
\text { and peak torque }\end{array}$ \\
\hline $\begin{array}{l}\text { Zainuddin et al. } \\
\text { (2005) }\end{array}$ & $\mathrm{RC}$ & 10 healthy subjects & $\begin{array}{l}\text { Hand and main } \\
\text { upper limb } \\
\text { muscles }\end{array}$ & $\begin{array}{l}\text { Effleurage, } \\
\text { petrissage, friction }\end{array}$ & $\begin{array}{l}10 \\
\mathrm{~min} / \text { post } \\
3 \mathrm{~h}\end{array}$ & $\begin{array}{l}\text { Elbow flexors } \\
\text { eccentric } \\
\text { exercises }\end{array}$ & No & $\begin{array}{l}\text { Arm massage } \\
\text { Arm control }\end{array}$ & $\begin{array}{l}\text { Pain VAS- } 10 \\
\text { Isometric and isokinetic } \\
\text { elbow flexor strength } \\
\text { Blood sample } \\
\text { pre- and post- TO, T+1, } \\
2,3,4,7,10,14 \text { days }\end{array}$ & $\begin{array}{l}\downarrow \text { DOMS } \\
\text { magnitude for } \\
\text { palaption and joint } \\
\text { mobilization } \\
\downarrow \text { creatine kinase } \\
\text { activity } \\
\text { NS change muscle } \\
\text { strength }\end{array}$ \\
\hline $\begin{array}{l}\text { Willems et al. } \\
\text { (2009) }\end{array}$ & $\mathrm{RCT}$ & $\begin{array}{l}7 \text { healthy and } \\
\text { moderately active }\end{array}$ & Quadriceps & $\begin{array}{l}\text { Effleurage, } \\
\text { petrissage }\end{array}$ & $25 \mathrm{~min}$ & $\begin{array}{l}20 \text { min downhill } \\
\text { treadmill walking } \\
\text { at } 25 \% \text { decline }\end{array}$ & No & $\begin{array}{l}\text { Leg massage } \\
\text { Leg control }\end{array}$ & $\begin{array}{l}\text { Quadriceps pain } \\
\text { VAS- } 10 \\
\text { Single limb jumps } \\
\text { pre- and post- } T+24 \text {, } \\
48,72 \mathrm{~h}\end{array}$ & $\begin{array}{l}\downarrow \text { DOMS vastus } \\
\text { lateralis and rectus } \\
\text { femoris at } 48 \mathrm{~h} \\
\uparrow \text { vertical power at } \\
48 \mathrm{~h}\end{array}$ \\
\hline
\end{tabular}

CT, clinical trial; RCT, randomized controlled trial; RC, randomized crossover; CCT, controlled clinical trial; DOMS, delayed onset muscle soreness; NR, not reported; $\uparrow$ indicates increase; $\downarrow$ indicates decrease; NS, not significant. 
that mechanical interventions mimicking MM could modulate inflammatory responses by local effects on interstitial fluid dynamics. The pressure exerted would induce a shear stress exertion on macrophages in situ, attenuating the phenomenon of muscle atrophy by a lymphatic and immune response (Saitou et al., 2018; Sakitani et al., 2019). In animal models, MM induces numerous neurophysiological changes. In fact, MM was associated with modulations in neural, lymphatic, and genetic responses (Lima et al., 2020). For example, abdominal massage improves transit in rats, i.e., reduced time to first fecal discharge in response to mechanical pressures. At the endocrine level, it was also shown that MM reduced the levels of gastrointestinal hormones, i.e., insulin, gastrin and somatostatin (Lima et al., 2020). MM also had modulatory effects at the neural level, since its analgesic effects were associated with changes in descending pain modulation circuits (Vigotsky and Bruhns, 2015). Nonetheless, the lack of consistency in the experimental findings in humans might be explained by a weak methodological rigor, as few protocols were reproduced and tested, hence supporting that there is no clear and precise design ensuring effectiveness of the intervention. The high variability of the studies is well-illustrated by the use of effleurage and petrissage techniques, while others also used friction, picking up, and shaking techniques. Likewise, the number of areas treated and the effective time of sport MM could fluctuate from 5 to $30 \mathrm{~min}$ (Brummitt, 2008; Poppendieck et al., 2016). Similarly, very few studies specified the intensity, the speed and the gestural frequency exerted by the therapist during the MM. Although these data are difficult to quantify, these parameters remain essential, as is the experience of the therapist, which has a main influence on MM effectiveness, and should be more rigorously controlled. Accordingly, Moraska (2007) provided evidence that therapist with $950 \mathrm{~h}$ of didactic training achieved significantly better results in muscle soreness than with 450 or $700 \mathrm{~h}$ of training. Although $\mathrm{MM}$ is an ancestral practice, this therapy, which is above all empirical, retains a certain number of gray areas, particularly in terms of sports massage, and the standardization of a sport MM protocol is warranted.

\section{Long-Term Intervention}

To prepare the body for an intense exercise or to facilitate the post-exercise recovery, longer-term repeated MM interventions have extensively been administered within a span of 2-5 weeks. One to two weekly MM sessions of 20-30 min were found to reduce the level of stress and fatigue (Leivadi et al., 1999; Jourdain, 2015). After a long-term exercise, a difference was noticed by the athletes after receiving a one-sided manual leg massage. According to the participants, the perception of recovery of the side massaged was greater than the control (Dawson et al., 2004). With regards to well-being, it seems that a regular MM makes increase neck and shoulder ROM (Leivadi et al., 1999; Yang et al., 2012). MM finally contributed to decrease the level of salivary cortisol after a period of 5 weeks, after a design including two massages per week (Leivadi et al., 1999). These various effects concurred with increased relaxation resulting from the activation of the parasympathetic nervous system.

\section{Experimental Procedures}

MM is universally appreciated. Classical guidelines emphasized the importance of dynamic movements for stimulating the soft tissues (e.g., vibration and tapotement). Slow gestures (e.g., effleurage, kneading, sliding pressure and friction) were recommended for well-being and relaxation. When the MM is designed to promote post-exercise recovery, effleurage and kneading should rather be preferred (Standley et al., 2010). Incorporating tapotements was further relevant to reduce DOMS and joint amplitude recovery, whereas vibration facilitated blood circulation and friction promoted relaxation (Standley et al., 2010). A cool-down MM routine using might last between 15 and $30 \mathrm{~min}$ to allow physiological changes (Standley et al., 2010). Despite guidelines, future experimental designs should consider and study the pressure levels and the gestural speed of the practitioner during MM to compensate for the lack of data.

\section{FOAM ROLLING}

FR is a self-myofascial release technique requiring direct contact with the skin, where fingers or tools are used to slowly press the fascial tissue. FR have extensively been adopted in fitness and conditioning communities in recent years (Cheatham and Stull, 2018a,b). Because of its simplicity and measurable effects, FR is administered as part of warm-up and recovery routines (Fleckenstein et al., 2017). Practically, FR administered using a foam roller, a roller massager, sticks or balls with varying sizes and density, further became very popular to improve functional outcomes such as ROM and pain pressure threshold (PPT). The first technique consists in performing simple back and forth movements, thus exerting mechanical pressures on soft tissues via the weight of the body (or the force of the upper limbs). A second technique, called ischemic pressure, requires a static pressure during a 6-30 s period, below the individual pain tolerance threshold (Abels, 2013; Myers, 2013; Kalichman and Ben David, 2017). This complementary approach is designed to reduce pain felt and improve ROM, but requires greater expertise with FR (Kalichman and Ben David, 2017). For users, the goal is to get closer from MM practice of the physiotherapist, more specifically to reproduce the method of Rolfing.

Although the scientific literature addressing the effects of FR remains sparse, this research topic is currently gaining attention (Cheatham et al., 2015; Wiewelhove et al., 2019; Figure 1). There is an emerging consensus that FR positively affects athletic performances such as power, strength, agility, balance and flexibility (Schroeder and Best, 2015). FR also yielded beneficial effects in rehabilitation settings with elderly populations or patients suffering from locomotor disorder such as genu varus (Jafarnezhadgero et al., 2018; Lee and Lim, 2018), round shoulder posture (Choi, 2019), or spastic diplegia (Patole et al., 2019). In the same vein, recent FR studies investigated its potential effectiveness in the context of rehabilitation (i.e., tendinopathies, friction syndrome of the iliotibial band, fibromyalgia, myofascial pain syndrome, or postural correction) (Grieve et al., 2013; Aboodarda et al., 2015; Chan et al., 2015; Ceca et al., 2017; Lee et al., 2017; Jafarnezhadgero et al., 2018). The theoretical rationale 


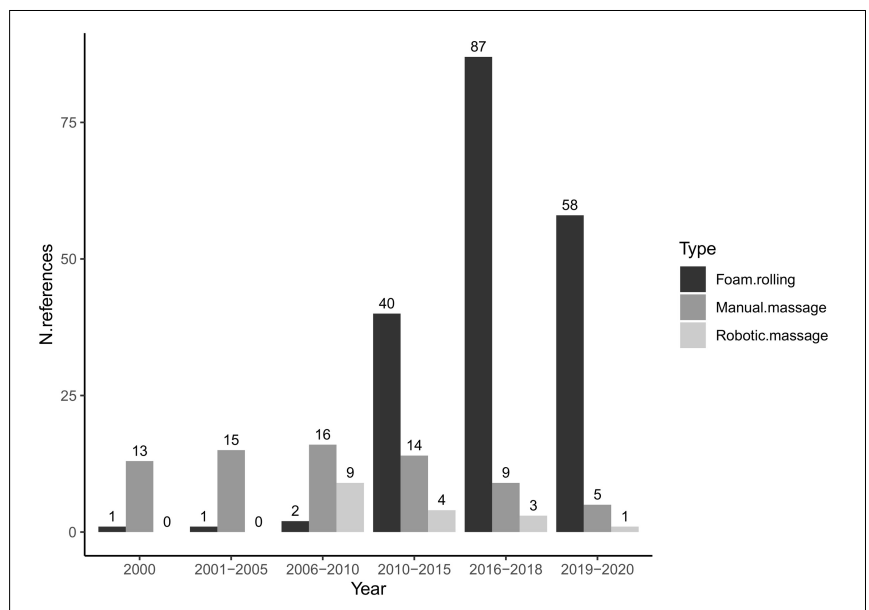

FIGURE 1 | The evolution of scientific interest according to the type of massage.

advanced as an account to the benefits of FR largely overlaps that for traditional MM.

\section{Dependent Variables}

\section{Psychometric and Behavioral Assessments}

As for MM, experimental designs seeking to assess the effectiveness of FR involved psychometric, behavioral and physiological measures. Subjective measures primarily consisted in standardized questionnaires and self-reports ratings on Likerttype scales to quantify pain and quality of life (Healey et al., 2014; Cavanaugh, 2016; Fleckenstein et al., 2017; Table 4). Researchers also used Borg scales or numerical ratings scale as means to collect perceived recovery (Healey et al., 2014; Peacock et al., 2015; Fleckenstein et al., 2017; Kalén et al., 2017; Rey et al., 2017; Beier et al., 2019; Table 4). Considering that pain is not objectively measurable, these different scales offer a simple solution to assess the quality and speed of recovery of DOMS (Jay et al., 2014; MacDonald et al., 2014; Romero-Moraleda et al., 2017, 2019; Naderi et al., 2019; Table 5). The algometer is also used to measure the PPT reliably, both at the muscular and joint levels, after FR routine. It is also used after exercise induced muscle damage and FR recovery (Pearcey et al., 2015; Correira, 2016; Casanova et al., 2017; Drinkwater et al., 2019; Table 5). Likewise, just like MM, functional tests, such as the sit-andreach or weight-bearing lunge tests, are usual tools to assess the effectiveness of FR on ROM (Sullivan et al., 2013; Halperin et al., 2014; Grieve et al., 2015; Peacock et al., 2015; Škarabot et al., 2015; Kelly and Beardsley, 2016; Patel et al., 2016; Boguszewski et al., 2017; Grabow et al., 2017; Jung et al., 2017; Paz et al., 2017; Sağiroğlu, 2017; Garcia-Gutiérrez et al., 2018; Phillips et al., 2018; Guillot et al., 2019; Pathania and Muragod, 2019; Somers et al., 2019; Williams and Selkow, 2019; Table 6). Other clinical examinations, such as the Thomas test or the straight leg raise test, are also regularly used to quantify flexibility with manual or electric goniometers after FR (MacDonald et al., 2014; Mohr et al., 2014; Cho et al., 2015; Vigotsky et al., 2015; Su et al., 2017; Do et al., 2018; Killen et al., 2018; Madoni et al., 2018;
Guillot et al., 2019; Jeong et al., 2019; Kyranoudis et al., 2019; Lim and Park, 2019; Oranchuk et al., 2019; Table 6). Applied to FR research, goniometer/inclinometer index gains in terms of degrees of freedom of the joints (Peacock et al., 2015; Škarabot et al., 2015; Fairall et al., 2017; Le Gal et al., 2018; Table 6). In addition to such flexibility tests, evaluating the effects of FR on physical qualities such as muscular power/strength, agility, and muscular activation, remains crucial (Mikesky et al., 2002; Fama and Bueti, 2011; Healey et al., 2014; Peacock et al., 2014, 2015).

\section{Neurophysiological Evaluations}

To this end, researchers used surface electromyography (EMGs) to appreciate whether muscle activation increase was associated with better performance, and further reduced the risk of injury (Macgregor et al., 2018). EMGs were recorded non-invasively by positioning electrodes directly on a shaved skin cleaned with alcohol (Ginszt et al., 2017; Romero-Moraleda et al., 2017; Hodgson et al., 2018; Madoni et al., 2018; Beier et al., 2019; Capobianco et al., 2019; Kim et al., 2019; Mazzei, 2019; Ye et al., 2019; Table 7). Recently, the development of tensiomyography allowed rapid and reliable non-invasive investigations of the contractile properties of the skeletal muscle (Martínez-Cabrera and Núñez-Sánchez, 2016; Murray et al., 2016; Schroeder et al., 2017; Macgregor et al., 2018; Table 7).

To complement the measurements made on the peripheral nervous system, other research was undertaken to increase the current understanding of the effects of FR to a more fundamental level. Researchers hypothesized that this technique was not limited to local changes in muscle tissues, but might also affect the vascular function. Some researchers collected blood analyses to measure concentrations of blood cortisol, lactate, oxytocin or even nitric oxide (Kim et al., 2014; Okamoto et al., 2014; D’Amico and Paolone, 2017; Kalén et al., 2017; Table 7). To overcome invasive constraints, they used an automatic blood pressure monitor, simple and quick to manipulate. This medical device consists of an inflatable cuff positioned on the arm. This device measures blood pressure by the oscillatory method, i.e., the heartbeats, pulse wave velocity, systolic and diastolic pressures (Okamoto et al., 2014; Lastova et al., 2018; Table 7). To achieve a more detailed analysis of both superficial and deep blood flow, ultrasound Doppler recordings were further used. This exploration is certainly more precise but requires specific knowledge in medical semiology as well as good adjustments of the device (Thistlethwaite et al., 2016; Hotfiel et al., 2017; Table 7). Formerly designed and reserved for the medical field, these advanced measurements are now gradually made available to applied research and extend current knowledge to FR. This recent spread comes in particular from a surge of recent interest from physiotherapists and rehabilitation professionals. Researchers therefore did not restrain their evaluation to functional tests for monitoring flexibility and muscle performance.

\section{Short-Term Effects}

Positive short-term FR effects, measured at a single-session level, were found to substantially reduce muscle pain (Schroeder and Best, 2015), in particular after exercise-induced muscle damage (Jay et al., 2014; MacDonald et al., 2014; Pearcey et al., 2015; 
TABLE 4 | The effects of foam rolling on psychological variables.

\begin{tabular}{|c|c|c|c|c|c|c|c|c|c|c|}
\hline \multirow[t]{2}{*}{ Author (year) } & \multirow{2}{*}{$\begin{array}{l}\text { Study } \\
\text { design }\end{array}$} & \multirow[t]{2}{*}{ Sample } & \multicolumn{4}{|c|}{ Foam rolling intervention } & \multirow[t]{2}{*}{ Control } & \multirow{2}{*}{$\begin{array}{l}\text { Others experimental } \\
\text { groups }\end{array}$} & \multirow{2}{*}{$\begin{array}{l}\text { Outcome } \\
\text { measures }\end{array}$} & \multirow[t]{2}{*}{ Effects } \\
\hline & & & Tool(s) & Targeted area & $\begin{array}{l}\text { Treatment } \\
\text { time and rate }\end{array}$ & Intensity & & & & \\
\hline $\begin{array}{l}\text { Peacock et al. } \\
\text { (2015) }\end{array}$ & $\mathrm{RC}$ & $\begin{array}{l}16 \text { athletically } \\
\text { trained adult }\end{array}$ & High density FR & $\begin{array}{l}\text { Main lower limb } \\
\text { muscles and lower } \\
\text { back }\end{array}$ & $\begin{array}{l}1 \times 30 \\
\text { s/muscle } 10 \\
\mathrm{bpm}\end{array}$ & $N R$ & No & $\begin{array}{l}\text { Sagittal plane FR } \\
\text { Frontal plane FR }\end{array}$ & Borg scale & $\begin{array}{l}\text { No change rate of } \\
\text { perceived exhaustion }\end{array}$ \\
\hline $\begin{array}{l}\text { Kalén et al. } \\
(2017)\end{array}$ & $\mathrm{RC}$ & $\begin{array}{l}12 \text { surf } \\
\text { lifeguards }\end{array}$ & High density FR & $\begin{array}{l}\text { Main lower limb } \\
\text { muscles per leg }\end{array}$ & $2 \times 60 s$ & $7 / 10$ & Yes & $\begin{array}{l}\text { Foam rolling } \\
\text { Running } \\
\text { Passive recovery }\end{array}$ & Borg CR-10 scale & $\begin{array}{l}\text { No change rate of } \\
\text { perceived exhaustion }\end{array}$ \\
\hline $\begin{array}{l}\text { Rey et al. } \\
\text { (2017) }\end{array}$ & $\mathrm{RCT}$ & $\begin{array}{l}18 \text { professional } \\
\text { soccer players }\end{array}$ & High density FR & $\begin{array}{l}\text { Main lower limb } \\
\text { muscles }\end{array}$ & $\begin{array}{l}1 \times 45 \mathrm{~s} / \mathrm{leg} \\
\text { and muscle } \\
\text { group } 50 \mathrm{bpm}\end{array}$ & $\begin{array}{l}\text { Much pressure as } \\
\text { they could }\end{array}$ & Yes & Foam rolling & $\begin{array}{l}\text { Total quality } \\
\text { recovery scale } \\
\text { Perceived muscle } \\
\text { soreness } \\
\text { VAS-7 }\end{array}$ & $\begin{array}{l}\uparrow \text { feelings of recovery } \\
\downarrow \text { perceived muscle } \\
\text { soreness at } 24 \mathrm{~h} \\
\text { post-training }\end{array}$ \\
\hline $\begin{array}{l}\text { Beier et al. } \\
\text { (2019) }\end{array}$ & $\mathrm{RC}$ & $\begin{array}{l}11 \text { resistance } \\
\text { trained subjects }\end{array}$ & Stick massage & $\begin{array}{l}\text { Rectus femoris and } \\
\text { gluteus maximus }\end{array}$ & $2 \mathrm{~min} /$ muscle & Heavy pressure & No & $\begin{array}{l}\text { Foam rolling } \\
\text { Dynamic warmup-up }\end{array}$ & Recovery scale-10 & $\begin{array}{l}\text { NS change perceived } \\
\text { recovery }\end{array}$ \\
\hline $\begin{array}{l}\text { Healey et al. } \\
\text { (2014) }\end{array}$ & $\mathrm{RC}$ & $\begin{array}{l}26 \text { healthy } \\
\text { college-aged } \\
\text { and } \\
\text { recreationally } \\
\text { active }\end{array}$ & High density FR & $\begin{array}{l}\text { Main lower limb } \\
\text { muscles and upper } \\
\text { back }\end{array}$ & $\begin{array}{l}1 \times 30 \\
\text { s/muscles }\end{array}$ & Self-selected & Yes & $\begin{array}{l}\text { Foam rolling } \\
\text { Planking exercises }\end{array}$ & $\begin{array}{l}\text { Borg CR-10 scale } \\
\text { Fatigue VAS-10 } \\
\text { Muscle soreness } \\
\text { VAS-10 } \\
\text { Palpating rating } \\
\text { soreness scale }\end{array}$ & $\begin{array}{l}\downarrow \text { fatigue } \\
\text { NS difference muscle } \\
\text { soreness }\end{array}$ \\
\hline $\begin{array}{l}\text { Cavanaugh } \\
\text { (2016) }\end{array}$ & $\mathrm{RC}$ & $\begin{array}{l}12 \text { healthy and } \\
\text { recreationnaly } \\
\text { active }\end{array}$ & $\begin{array}{l}\text { Roller } \\
\text { massager }\end{array}$ & Plantar flexors & $\begin{array}{l}3 \times 30 \mathrm{~s} \\
15 \mathrm{bpm}\end{array}$ & $7 / 100 / 10$ & Yes & $\begin{array}{l}\text { Foam rolling ipsilaetral } \\
\text { leg }(7 / 10) \\
\text { Foam rolling } \\
\text { contralateral leg }(7 / 10) \\
\text { Sham }(0 / 10)\end{array}$ & Pain VAS-10 & $\begin{array}{l}\downarrow \text { pain perception with } \\
\text { heavy foam rolling }\end{array}$ \\
\hline $\begin{array}{l}\text { Cheatham et al. } \\
\text { (2017) }\end{array}$ & $\mathrm{RCT}$ & $\begin{array}{l}45 \text { healthy } \\
\text { subjects }\end{array}$ & High density FR & Quadriceps & $1 \times 120 s$ & Moderate & Yes & $\begin{array}{l}\text { Video-guided } \\
\text { Live-instructed } \\
\text { Self-guided } \\
\text { foam rolling + knee } \\
\text { mobilizations }\end{array}$ & Quadriceps PPT & $\begin{array}{l}\text { All groups : } \uparrow \text { muscle } \\
\text { tenderness }\end{array}$ \\
\hline $\begin{array}{l}\text { Cheatham et al. } \\
\text { (2019) }\end{array}$ & $\mathrm{RCT}$ & $\begin{array}{l}45 \text { healthy and } \\
\text { recreationnaly }\end{array}$ & $\begin{array}{l}\text { Vibrating foam } \\
\text { roller Non } \\
\text { vibrating foam } \\
\text { roller }\end{array}$ & Quadriceps & $1 \times 120 s$ & Moderate & Yes & $\begin{array}{l}\text { Vibratinh foam rolling } \\
(33 \mathrm{~Hz}) \\
\text { Non-ibrating foam } \\
\text { rolling + knee } \\
\text { mobilizations }\end{array}$ & $\begin{array}{l}\text { Quadriceps PPT } \\
\text { Passive knee } \\
\text { flexion ROM }\end{array}$ & $\begin{array}{l}\text { Both groups } \\
\uparrow \text { knee ROM } \\
\uparrow \text { muscle tenderness } \\
\text { (vibrating > non-vibrating) }\end{array}$ \\
\hline $\begin{array}{l}\text { Cheatham and } \\
\text { Baker (2017) }\end{array}$ & $\mathrm{RCT}$ & $\begin{array}{l}20 \text { healthy } \\
\text { subjects }\end{array}$ & High density FR & Quadriceps & $\begin{array}{l}1 \times 120 \mathrm{~s} \\
1 \text { inch per } \\
\text { second }\end{array}$ & Moderate & No & $\begin{array}{l}\text { Foam rolling leg Control } \\
\text { leg + knee } \\
\text { mobilizations }\end{array}$ & $\begin{array}{l}\text { Quadriceps and } \\
\text { hamstrings PPT }\end{array}$ & $\begin{array}{l}\uparrow \text { muscle tenderness } \\
\text { (crossover effect on } \\
\text { contralateral quadriceps) }\end{array}$ \\
\hline
\end{tabular}


TABLE 4 | Continued

\begin{tabular}{|c|c|c|c|c|c|c|c|c|c|c|}
\hline \multirow[t]{2}{*}{ Author (year) } & \multirow{2}{*}{$\begin{array}{l}\text { Study } \\
\text { design }\end{array}$} & \multirow[t]{2}{*}{ Sample } & \multicolumn{4}{|c|}{ Foam rolling intervention } & \multirow[t]{2}{*}{ Control } & \multirow{2}{*}{$\begin{array}{l}\text { Others experimental } \\
\text { groups }\end{array}$} & \multirow{2}{*}{$\begin{array}{l}\text { Outcome } \\
\text { measures }\end{array}$} & \multirow[t]{2}{*}{ Effects } \\
\hline & & & Tool(s) & Targeted area & $\begin{array}{l}\text { Treatment } \\
\text { time and rate }\end{array}$ & Intensity & & & & \\
\hline $\begin{array}{l}\text { Fleckenstein } \\
\text { et al. (2017) }\end{array}$ & RCT & $\begin{array}{l}55 \text { healthy and } \\
\text { recreationally } \\
\text { active }\end{array}$ & High density FR & $\begin{array}{l}\text { Mam lower limb } \\
\text { muscles }\end{array}$ & $\begin{array}{l}1 \times 30 \mathrm{~s} / \mathrm{muscle} \\
60 \mathrm{bpm}\end{array}$ & $7 / 10$ & Yes & $\begin{array}{l}\text { Prevention } \\
\text { Regeneration }\end{array}$ & $\begin{array}{l}\text { Fatigue VAS-10 } \\
\text { Pain VAS-10 }\end{array}$ & $\begin{array}{l}\downarrow \text { perceived fatigue } \\
\text { (regeneration > } \\
\text { prevention) }\end{array}$ \\
\hline $\begin{array}{l}\text { Han et al. } \\
(2017)\end{array}$ & RCT & $\begin{array}{l}30 \text { students } \\
\text { patients will } \\
\text { trigger point }\end{array}$ & $\begin{array}{l}\text { Vibrating FR } \\
\text { Non-vibrating } \\
\text { FR }\end{array}$ & $\begin{array}{l}\text { Mam lower limb } \\
\text { muscles }\end{array}$ & $1 \times 20 \min$ & $N R$ & No & $\begin{array}{l}\text { Vibrating FR }(62 \mathrm{~Hz}) \\
\text { Non-vibrating FR } \\
3 \text { times/week over } \\
\text { 4-weeks }\end{array}$ & $\begin{array}{l}\text { liotibial-band, } \\
\text { gluteus, rectus } \\
\text { femoris, hamstrings } \\
\text { PPT }\end{array}$ & $\begin{array}{l}\uparrow \text { muscle tenderness in } \\
\text { ITB Trend } \uparrow \text { for others } \\
\text { muscles }\end{array}$ \\
\hline $\begin{array}{l}\text { Cheatham and } \\
\text { Stull (2018a) }\end{array}$ & $\mathrm{RCT}$ & $\begin{array}{l}21 \text { healthy } \\
\text { subjects }\end{array}$ & High density FR & Quadriceps & $\begin{array}{l}1 \times 120 \mathrm{~s} \\
1 \text { inch per } \\
\text { second }\end{array}$ & Moderate & No & $\begin{array}{l}\text { Foam rolling leg } \\
\text { Control leg + knee } \\
\text { mobilizations }\end{array}$ & $\begin{array}{l}\text { Quadriceps and } \\
\text { hamstrings PPT }\end{array}$ & $\begin{array}{l}\uparrow \text { muscle tenderness } \\
\text { (crossover effect on } \\
\text { contralateral quadriceps) }\end{array}$ \\
\hline $\begin{array}{l}\text { Cheatham and } \\
\text { Stull (2018a) }\end{array}$ & RCT & $\begin{array}{l}36 \text { healthy and } \\
\text { recreationally } \\
\text { active }\end{array}$ & $\begin{array}{l}\text { Soft FR } \\
\text { Medium FR } \\
\text { Hard FR }\end{array}$ & Quadriceps & $\begin{array}{l}1 \times 120 \mathrm{~s} \\
1 \text { inch per } \\
\text { second }\end{array}$ & $N R$ & No & $\begin{array}{l}\text { Soft density FR } \\
\text { Medium density FR } \\
\text { Hard density FR + knee } \\
\text { mobilizations }\end{array}$ & Quadriceps PPT & $\begin{array}{l}\text { Three groups } \uparrow \text { muscle } \\
\text { tenderness }\end{array}$ \\
\hline $\begin{array}{l}\text { Cheatham and } \\
\text { Stull (2018b) }\end{array}$ & $\mathrm{RCT}$ & $\begin{array}{l}30 \text { healthy and } \\
\text { recreationally } \\
\text { active }\end{array}$ & High density FR & Quadriceps & $\begin{array}{l}1 \times 120 \mathrm{~s} \\
1 \text { inch per } \\
\text { second }\end{array}$ & $N R$ & No & $\begin{array}{l}\text { Foam rolling only Foam } \\
\text { rolling + knee } \\
\text { mobilizations }\end{array}$ & Quadriceps PPT & $\begin{array}{l}\uparrow \text { muscle tenderness } \\
\text { (foam rolling with knee } \\
\text { mobilizations > foam } \\
\text { rolling only) }\end{array}$ \\
\hline $\begin{array}{l}\text { Cheatham et al. } \\
\text { (2019) }\end{array}$ & $\mathrm{RCT}$ & $\begin{array}{l}45 \text { healthy and } \\
\text { recreationally } \\
\text { active }\end{array}$ & $\begin{array}{l}\text { Vibrating FR } \\
\text { Non vibrating } \\
\text { FR }\end{array}$ & Quadriceps & $\begin{array}{l}1 \times 120 \mathrm{~s} \\
1 \text { inch per } \\
\text { second }\end{array}$ & $N R$ & Yes & $\begin{array}{l}\text { Vibrating FR(33 Hz) } \\
\text { Non-vibrating FR Static } \\
\text { stretching }\end{array}$ & Quadriceps PPT & $\begin{array}{l}\uparrow \text { muscle tenderness } \\
\text { (vibrating > non-vibrating } \\
\text { FR) }\end{array}$ \\
\hline
\end{tabular}

$R C$, randomized crossover: RCT, randomized controlled trial; FR: foam roller; NR, not reported; bpm, beats per minute: $\uparrow$ indicates increase; $\downarrow$ indicates decrease; VAS, visual analogue scale: PPT, pain pressure threshold; NS, not statistically significant. 
TABLE 5 | The effects of foam rolling on delayed-onset muscle soreness.

\begin{tabular}{|c|c|c|c|c|c|c|c|c|c|c|c|c|}
\hline \multirow{2}{*}{$\begin{array}{l}\text { Author } \\
\text { (year) }\end{array}$} & \multirow{2}{*}{$\begin{array}{l}\text { Study } \\
\text { design }\end{array}$} & \multirow[t]{2}{*}{ Sample } & \multicolumn{5}{|c|}{ Foam rolling intervention } & \multirow{2}{*}{$\begin{array}{l}\text { Nature of } \\
\text { exercise }\end{array}$} & \multirow[t]{2}{*}{ Control } & \multirow{2}{*}{$\begin{array}{l}\text { Others } \\
\text { experimental } \\
\text { groups }\end{array}$} & \multirow[t]{2}{*}{ Outcome measures } & \multirow[t]{2}{*}{ Effects } \\
\hline & & & Tool(s) & Targeted area & $\begin{array}{l}\text { Treatment } \\
\text { time and } \\
\text { rate }\end{array}$ & Intensity & Experience & & & & & \\
\hline $\begin{array}{l}\text { Casanova } \\
\text { et al. (2017) }\end{array}$ & $\mathrm{RC}$ & 10 athletes & $\begin{array}{l}\text { Roller } \\
\text { massager }\end{array}$ & Plantar flexors & $\begin{array}{l}6 \times 45 \mathrm{~s} \\
30 \mathrm{bpm}\end{array}$ & $N R$ & $\begin{array}{l}1 \text { test } \\
\text { session }\end{array}$ & $\begin{array}{l}5 \times 201-\mathrm{leg} \\
\text { calf raise at BW }\end{array}$ & Yes & $\begin{array}{l}\text { Foam rolling leg } \\
\text { Control leg }\end{array}$ & $\begin{array}{l}\text { Gastrocnemius PPT } \\
\text { Ankle dorsiflexion } \\
\text { Muscle morphology } \\
\text { Muscle oxygenation } \\
\text { Plantar flexion, } \\
\text { dorsiflexion MVIC } \\
\text { pre- and post-TO, T+1, } \\
24,48,72 \mathrm{~h}\end{array}$ & $\begin{array}{l}\uparrow \text { muscle tenderness } \\
\uparrow \text { ankle ROM } \\
\text { NS change muscle } \\
\text { oxygenation (HHb } \\
\text { concentration) } \\
\text { NS change muscle } \\
\text { morphology } \\
\text { NS change muscle } \\
\text { performance }\end{array}$ \\
\hline $\begin{array}{l}\text { Jay et al. } \\
\text { (2014) }\end{array}$ & $\mathrm{RCT}$ & $\begin{array}{l}22 \text { healthy } \\
\text { untrained }\end{array}$ & $\begin{array}{l}\text { Roller } \\
\text { massager }\end{array}$ & Hamstring & $\begin{array}{l}1 \times 10 \mathrm{~min} \\
15-30 \mathrm{bpm}\end{array}$ & Moderate & $N R$ & $\begin{array}{l}10 \times 10 \\
\text { stiff-legged } \\
\text { deadlift up to } \\
32 \mathrm{~kg}\end{array}$ & Yes & $\begin{array}{l}\text { Foam rolling leg } \\
\text { Control leg }\end{array}$ & $\begin{array}{l}\text { Pain VAS-10 } \\
\text { Hamstrings PPT } \\
\text { 1-leg sit-and-reach box } \\
\text { test } \\
\text { pre- and post- T0, } \\
\mathrm{T}+10,30,60 \text { min }\end{array}$ & $\begin{array}{l}\uparrow \text { muscle tenderness up } \\
\text { to } 60 \text { min } \\
\downarrow \text { muscle soreness up to } \\
60 \text { min } \\
\uparrow \text { ROM at } 10 \text { min } \\
\\
\text { Controlateral effect } \\
\downarrow \text { muscle soreness } \\
\text { Tend } \uparrow \text { muscle } \\
\text { tenderness } \\
\text { Trend } \uparrow \text { ROM }\end{array}$ \\
\hline $\begin{array}{l}\text { MacDonald } \\
\text { et al. (2014) }\end{array}$ & $\mathrm{RCT}$ & $\begin{array}{l}20 \text { healthy and } \\
\text { recreationally } \\
\text { active }\end{array}$ & $\begin{array}{l}\text { High density } \\
\text { FR }\end{array}$ & $\begin{array}{l}\text { Main lower limb } \\
\text { muscles }\end{array}$ & $\begin{array}{l}2 \times 60 \\
\text { s/muscle }\end{array}$ & $N R$ & $\begin{array}{l}1 \text { test } \\
\text { session }\end{array}$ & $\begin{array}{l}10 \times 10 \text { squat } \\
\text { at } 60 \% \text { of } 1-\mathrm{RM}\end{array}$ & Yes & Foam rolling & $\begin{array}{l}\text { BS-11 NRS } \\
\text { Modified kneeling lunge } \\
\text { Physical test and } \\
\text { contractile properties } \\
\text { pre- and post-T0, } \\
\mathrm{T}+48,72 \mathrm{~h}\end{array}$ & $\begin{array}{l}\downarrow \text { muscle soreness } \\
\uparrow \text { performances } \\
\uparrow \text { muscle activity }\end{array}$ \\
\hline $\begin{array}{l}\text { Pearcey } \\
\text { et al. (2015) }\end{array}$ & $\mathrm{RC}$ & $\begin{array}{l}8 \text { healthy and } \\
\text { physically active }\end{array}$ & $\begin{array}{l}\text { High density } \\
\text { FR }\end{array}$ & $\begin{array}{l}\text { Main lower limb } \\
\text { muscles }\end{array}$ & $\begin{array}{l}2 \times 45 \\
\mathrm{~s} / \mathrm{muscle} \\
50 \mathrm{bpm}\end{array}$ & $\begin{array}{l}\text { Much } \\
\text { pressure as } \\
\text { they could }\end{array}$ & Yes & $\begin{array}{l}10 \times 10 \text { squat } \\
\text { at } 60 \% \text { of } 1-\mathrm{RM}\end{array}$ & Yes & Foam rolling & $\begin{array}{l}\text { Quadriceps PPT } \\
\text { Physical tests } \\
\text { pre- and post- } T+24 \text {, } \\
48,72 \mathrm{~h}\end{array}$ & $\begin{array}{l}\uparrow \text { muscle tenderness } \\
\uparrow \text { physical performance } \\
\text { decrements }\end{array}$ \\
\hline $\begin{array}{l}\text { Correira } \\
\text { (2016) }\end{array}$ & $\mathrm{RC}$ & $\begin{array}{l}10 \text { healthy and } \\
\text { recreationnaly } \\
\text { active }\end{array}$ & $\begin{array}{l}\text { Roller } \\
\text { massager }\end{array}$ & Plantar flexors & $\begin{array}{l}6 \times 45 \mathrm{~s} \\
30 \mathrm{bpm}\end{array}$ & $\begin{array}{l}\text { Much } \\
\text { pressure as } \\
\text { they could }\end{array}$ & $\begin{array}{l}1 \text { test } \\
\text { session }\end{array}$ & $\begin{array}{l}5 \times 201 \text {-leg } \\
\text { calf raise at BW }\end{array}$ & Yes & Foam rolling & $\begin{array}{l}\text { Plantar PPT } \\
\text { Dorsiflexion ROM } \\
\text { Plantar MVIC } \\
\text { Muscle morphology } \\
\text { Muscle oxygenation } \\
\text { pre- and post- T0, } \\
\text { T+1 h, 24, 48, } 72 \text { h }\end{array}$ & $\begin{array}{l}\uparrow \text { muscle tenderness at } \\
\mathrm{T}+24 \mathrm{~h}, 48 \mathrm{~h}, 72 \mathrm{~h} \\
\mathrm{NS} \text { change ROM } \\
\text { NS change muscular } \\
\text { performance } \\
\text { NS change morphology } \\
\text { NS change muscle } \\
\text { oxygenation }\end{array}$ \\
\hline
\end{tabular}


TABLE 5 | Continued

\begin{tabular}{|c|c|c|c|c|c|c|c|c|c|c|c|c|}
\hline \multirow{2}{*}{$\begin{array}{l}\text { Author } \\
\text { (year) }\end{array}$} & \multirow{2}{*}{$\begin{array}{l}\text { Study } \\
\text { design }\end{array}$} & \multirow[t]{2}{*}{ Sample } & \multicolumn{5}{|c|}{ Foam rolling intervention } & \multirow{2}{*}{$\begin{array}{l}\text { Nature of } \\
\text { exercise }\end{array}$} & \multirow[t]{2}{*}{ Control } & \multirow{2}{*}{$\begin{array}{l}\text { Others } \\
\text { experimental } \\
\text { groups }\end{array}$} & \multirow[t]{2}{*}{ Outcome measures } & \multirow[t]{2}{*}{ Effects } \\
\hline & & & Tool(s) & Targeted area & $\begin{array}{l}\text { Treatment } \\
\text { time and } \\
\text { rate }\end{array}$ & Intensity & Experience & & & & & \\
\hline $\begin{array}{l}\text { Romero- } \\
\text { Moraleda } \\
\text { et al. (2017) }\end{array}$ & $\mathrm{RCT}$ & $\begin{array}{l}32 \text { healthy and } \\
\text { moderately active }\end{array}$ & $\begin{array}{l}\text { High density } \\
\text { FR }\end{array}$ & Quadriceps & $5 \times 60 s$ & $\begin{array}{l}\text { Much } \\
\text { pressure as } \\
\text { they could }\end{array}$ & $N R$ & $\begin{array}{l}5 \times 20 \\
0,5 \mathrm{~m} \text { drop } \\
\text { jumps }\end{array}$ & No & $\begin{array}{l}\text { Neurodynamic } \\
\text { mobilization } \\
\text { Foam rolling }\end{array}$ & $\begin{array}{l}\text { Numerical pain rating } \\
\text { scale-10 } \\
\text { Knee extension MVIC }\end{array}$ & $\begin{array}{l}\text { Both groups : } \downarrow \text { muscle } \\
\text { pain Foam roller group } \\
\uparrow \text { muscle strength }\end{array}$ \\
\hline $\begin{array}{l}\text { Drinkwater } \\
\text { et al. (2019) }\end{array}$ & $\mathrm{RC}$ & $\begin{array}{l}11 \text { healthy young } \\
\text { males }\end{array}$ & $\begin{array}{l}\text { High density } \\
\text { FR }\end{array}$ & $\begin{array}{l}\text { Main lower limb } \\
\text { muscles }\end{array}$ & $\begin{array}{l}1 \times 180 \\
\text { s/muscle } \\
60 \text { bpm }\end{array}$ & $\begin{array}{l}\text { Much } \\
\text { pressure as } \\
\text { they could }\end{array}$ & $\begin{array}{l}1 \text { test } \\
\text { session }\end{array}$ & $\begin{array}{l}6 \times 25 \\
\text { eccentric knee } \\
\text { extensors at } \\
120 \% \text { s }\end{array}$ & Yes & $\begin{array}{l}\text { Foam rolling } \\
\text { post-T0 and } \\
\text { before each } \\
\text { testing point at } \\
\mathrm{T}+24,48,72 \mathrm{~h}\end{array}$ & $\begin{array}{l}\text { PPT rectus femoris } \\
\text { Mid-thigh } \\
\text { circumference } \\
\text { Knee flexion ROM } \\
\text { CMJ } \\
\text { MVIC right knee } \\
\text { extensor }\end{array}$ & $\begin{array}{l}\uparrow \text { muscle tenderness at } \\
T+48 \mathrm{~h} \\
\text { NS change circumference } \\
\text { NS change knee ROM } \\
\uparrow \text { vertical jump at } 72 \mathrm{~h} \\
\text { NS change strength }\end{array}$ \\
\hline $\begin{array}{l}\text { Naderi } \\
\text { et al. (2019) }\end{array}$ & $\mathrm{RCT}$ & $\begin{array}{l}80 \text { healthy } \\
\text { physically active } \\
\text { male }\end{array}$ & $\begin{array}{l}\text { High density } \\
\text { FR }\end{array}$ & Quadriceps & $\begin{array}{l}4 \times 120 \mathrm{~s} \\
30 \mathrm{bpm}\end{array}$ & $\begin{array}{l}\text { Much } \\
\text { pressure as } \\
\text { they could }\end{array}$ & $\begin{array}{l}1 \text { test } \\
\text { session }\end{array}$ & $\begin{array}{l}4 \times 25 \\
\text { eccentric knee } \\
\text { extensors at } \\
60^{\circ} / \mathrm{s}\end{array}$ & Yes & $\begin{array}{l}\text { Foam rolling } \\
\text { post- } \mathrm{TO}, \mathrm{T}+1 \text {, } \\
24,48,72 \mathrm{~h}\end{array}$ & $\begin{array}{l}\text { Pain VAS-10 } \\
\text { PPT } \\
\text { Quadriceps muscle } \\
\text { strength } \\
\text { Joint position sense } \\
\text { Isometric force sense } \\
\text { pre- and post- } \mathrm{T}+1 \text {, } \\
\mathrm{T}+24,48,72 \mathrm{~h}\end{array}$ & $\begin{array}{l}\downarrow \text { muscle pain } \\
\uparrow \text { muscle tenderness } \\
\uparrow \text { proprioception } \\
\downarrow \text { force decrements up to } \\
48 \mathrm{~h}\end{array}$ \\
\hline $\begin{array}{l}\text { Romero- } \\
\text { Moraleda } \\
\text { et al. (2019) }\end{array}$ & $\mathrm{RCT}$ & $\begin{array}{l}38 \text { healthy and } \\
\text { moderately active }\end{array}$ & $\begin{array}{l}\text { Vibrating FR } \\
\text { Non-vibrating } \\
\text { FR }\end{array}$ & Quadriceps & $5 \times 60 s$ & $\begin{array}{l}\text { Much } \\
\text { pressure as } \\
\text { they could }\end{array}$ & $N R$ & $\begin{array}{l}10 \times 10 \text { inertial } \\
\text { flywheel } \\
\text { eccentric squat }\end{array}$ & No & $\begin{array}{l}\text { Foam rolling with } \\
\text { vibrating roller } \\
(18 \mathrm{~Hz}) \\
\text { Foam rolling with } \\
\text { classic roller }\end{array}$ & $\begin{array}{l}\text { Pain VAS-10 } \\
\text { Quadriceps PPT } \\
\text { Muscle oxygen } \\
\text { saturation } \\
\text { CMJ } \\
\text { Active and passive hip } \\
\text { extension ROM } \\
\text { Knee flexion ROM }\end{array}$ & $\begin{array}{l}\text { Vibrating > non-vibrating } \\
\text { FR } \\
\uparrow \text { muscle tenderness } \\
\downarrow \text { pain perception } \\
\uparrow \text { passive hip extension } \\
\\
\text { Both FR } \\
\uparrow \text { muscle oxygenation } \\
\text { (SmO2) } \\
\uparrow \text { vertical power } \\
\uparrow \text { active hip and knee } \\
\text { ROM }\end{array}$ \\
\hline
\end{tabular}

RC, randomized crossover; $R C T$, randomized controlled trial; FR, foam roller, BW, body weight; VAS, visual analogue scale; PPT, pressure pain threshold; NR, not reported; bpm, beats per minute; NS, not significant; $\uparrow$ indicates increase; $\downarrow$ indicates decrease. 
TABLE 6 | The effects of foam rolling on range of motion

\begin{tabular}{|c|c|c|c|c|c|c|c|c|c|c|c|}
\hline \multirow{2}{*}{$\begin{array}{l}\text { Author } \\
\text { (year) }\end{array}$} & \multirow{2}{*}{$\begin{array}{l}\text { Study } \\
\text { design }\end{array}$} & \multirow[t]{2}{*}{ Sample } & \multicolumn{4}{|c|}{ Foam rolling intervention } & \multirow[b]{2}{*}{ Expertise } & \multirow[t]{2}{*}{ Control } & \multirow{2}{*}{$\begin{array}{l}\text { Others experimental } \\
\text { groups }\end{array}$} & \multirow{2}{*}{$\begin{array}{l}\text { Outcome } \\
\text { measures }\end{array}$} & \multirow[t]{2}{*}{ Effects } \\
\hline & & & Tool(s) & Targeted area & $\begin{array}{l}\text { Treatment } \\
\text { time and rate }\end{array}$ & $\begin{array}{l}\text { Intensity } \\
\text { (VAS) }\end{array}$ & & & & & \\
\hline $\begin{array}{l}\text { Peacock } \\
\text { et al. (2015) }\end{array}$ & $\mathrm{RC}$ & $\begin{array}{l}16 \text { athletically } \\
\text { trained }\end{array}$ & High density FR & $\begin{array}{l}\text { Main muscle of } \\
\text { the body }\end{array}$ & $\begin{array}{l}1 \times 30 \mathrm{~s} / \text { muscle } \\
10 \mathrm{bpm}\end{array}$ & $N R$ & $N R$ & No & $\begin{array}{l}\text { Mediolateral plan } \\
\text { Anteroposterior plan }\end{array}$ & SBRT & $\begin{array}{l}\text { Mediolateral FR plan } \\
\uparrow \text { lower back and } \\
\text { hamstring flexibility }\end{array}$ \\
\hline $\begin{array}{l}\text { Škarabot } \\
\text { et al. (2015) }\end{array}$ & $\mathrm{RC}$ & $\begin{array}{l}11 \text { adolescents } \\
\text { trained swimmers }\end{array}$ & High density FR & Plantar flexors & $3 \times 30 s$ & 7/10 VAS & 6-months & No & $\begin{array}{l}\text { Static Stretching } \\
\text { Foam rolling } \\
\text { Foam rolling + Static } \\
\text { stretching }\end{array}$ & WBLT & $\begin{array}{l}\text { Ankle dorsiflexion ROM } \\
\text { FR group : NS change } \\
\text { SS group : } \uparrow \\
\text { Combination group : } \uparrow\end{array}$ \\
\hline $\begin{array}{l}\text { Fairall et al. } \\
\text { (2017) }\end{array}$ & $\mathrm{RCT}$ & $\begin{array}{l}12 \text { adult amateur } \\
\text { softball players with } \\
\text { shoulder ROM }\end{array}$ & Lacrosse ball & Infraspinatus & $2 \times 60 s$ & $N R$ & No & No & $\begin{array}{l}\text { Foam rolling alone } \\
\text { Static stretching alone } \\
\text { Foam rolling + Static } \\
\text { stretching }\end{array}$ & $\begin{array}{l}\text { Glenohumeral } \\
\text { internal rotation }\end{array}$ & $\begin{array}{l}\mathrm{FR}+\mathrm{SS} \text { and } \mathrm{SS}>\mathrm{FR} \\
\uparrow \text { shoulder ROM }\end{array}$ \\
\hline $\begin{array}{l}\text { Le Gal et al. } \\
\text { (2017) }\end{array}$ & $\mathrm{RCT}$ & $\begin{array}{l}11 \text { adolescent } \\
\text { advanced tennis } \\
\text { players }\end{array}$ & Tennis ball & $\begin{array}{l}\text { Infraspinatus } \\
\text { and pectoralis }\end{array}$ & $3 \times 60 \mathrm{~s} /$ muscle & $\begin{array}{l}\text { Much pressure } \\
\text { as they could }\end{array}$ & NR & Yes & $\begin{array}{l}\text { Foam rolling } \\
3 \text { times/week over } \\
\text { 5-weeks }\end{array}$ & $\begin{array}{l}\text { Glenohumeral } \\
\text { internal rotation }\end{array}$ & $\begin{array}{l}\uparrow \text { shoulder ROM at } \\
5 \text {-weeks }\end{array}$ \\
\hline $\begin{array}{l}\text { Sağiroğlu } \\
\text { (2017) }\end{array}$ & $\mathrm{RC}$ & $\begin{array}{l}22 \text { well-trained } \\
\text { soccer players }\end{array}$ & $\begin{array}{l}\text { Vibrating FR } \\
\text { Non vibrating } \\
\text { FR }\end{array}$ & $\begin{array}{l}\text { Main lower limb } \\
\text { muscles }\end{array}$ & $\begin{array}{l}2 \times 30 \mathrm{~s} / \text { muscle } \\
10 \mathrm{bpm}\end{array}$ & NR & No & No & $\begin{array}{l}\text { Foam rolling with } \\
\text { vibrating roller }(38 \mathrm{~Hz}) \\
\text { Foam rolling with } \\
\text { classic roller }\end{array}$ & SRBT & $\begin{array}{l}\text { Both experimental } \\
\text { groups : } \uparrow \text { lower back } \\
\text { and hamstring flexibility } \\
\text { without no difference } \\
\text { between }\end{array}$ \\
\hline $\begin{array}{l}\text { Guillot et al. } \\
\text { (2019) }\end{array}$ & $\mathrm{RCT}$ & $\begin{array}{l}30 \text { professional } \\
\text { rugby players }\end{array}$ & High density FR & $\begin{array}{l}\text { Main lower limb } \\
\text { muscles }\end{array}$ & $\begin{array}{l}1 \times 20-40 \\
\text { s/muscle } \\
21 \mathrm{bpm}\end{array}$ & $\begin{array}{l}\text { Much pressure } \\
\text { as they could }\end{array}$ & $\begin{array}{l}1 \text { test } \\
\text { session }\end{array}$ & Yes & $\begin{array}{l}\text { Foam rolling } \\
1 \text { set of } 20 \mathrm{~s} \\
1 \text { sets of } 40 \mathrm{~s} \\
3 \text { times/week over } \\
5 \text {-weeks }\end{array}$ & $\begin{array}{l}\text { Side split test } \\
\text { Active SLR } \\
\text { Modified Thomas } \\
\text { test WBLT }\end{array}$ & $\begin{array}{l}\text { Both FR groups : } \\
\text { without S difference } \\
\text { between FR groups } \\
\uparrow \text { hip ROM } \\
\text { NS change knee ROM } \\
\text { NS change dorsiflexion } \\
\text { Perceived discomfort } \\
40 s>20 s\end{array}$ \\
\hline $\begin{array}{l}\text { Oranchuk } \\
\text { et al. (2019) }\end{array}$ & $\mathrm{RC}$ & $\begin{array}{l}22 \text { female NCAA } \\
\text { Division II lacrosse } \\
\text { and soccer athletes }\end{array}$ & $\begin{array}{l}\text { High density } \\
\text { foam roller }\end{array}$ & Hamstrings & $\begin{array}{l}3 \times 60 \mathrm{~s} \\
30 \mathrm{bpm}\end{array}$ & $\begin{array}{l}\text { Much pressure } \\
\text { as they could }\end{array}$ & $\begin{array}{l}1 \text { test } \\
\text { session }\end{array}$ & Yes & $\begin{array}{l}\text { Foam rolling (FR) } \\
\text { Superficial heating (SH) } \\
\text { Superficial heating + } \\
\text { Foam rolling }\end{array}$ & $\begin{array}{l}\text { Passive SLR } \\
\text { Likert scale } \\
\text { (perceptions of } \\
\text { efficacy) }\end{array}$ & $\begin{array}{l}\mathrm{SH}, \mathrm{SH}+\mathrm{FR}>\text { Control } \\
\mathrm{SH}+\mathrm{FR}>\mathrm{FR} \text { or } \mathrm{SH} \\
\uparrow \text { hip flexion ROM } \\
\mathrm{SH}+\mathrm{FR}>\mathrm{FR} \text { but not } \\
\mathrm{SH} \text { more effective } \\
\text { perception }\end{array}$ \\
\hline
\end{tabular}


TABLE 6 | Continued

\begin{tabular}{|c|c|c|c|c|c|c|c|c|c|c|c|}
\hline \multirow{2}{*}{$\begin{array}{l}\text { Author } \\
\text { (year) }\end{array}$} & \multirow{2}{*}{$\begin{array}{l}\text { Study } \\
\text { design }\end{array}$} & \multirow[t]{2}{*}{ Sample } & \multicolumn{4}{|c|}{ Foam rolling intervention } & \multirow[b]{2}{*}{ Expertise } & \multirow[t]{2}{*}{ Control } & \multirow{2}{*}{$\begin{array}{l}\text { Others experimental } \\
\text { groups }\end{array}$} & \multirow{2}{*}{$\begin{array}{l}\text { Outcome } \\
\text { measures }\end{array}$} & \multirow[t]{2}{*}{ Effects } \\
\hline & & & Tool(s) & Targeted area & $\begin{array}{l}\text { Treatment } \\
\text { time and rate }\end{array}$ & $\begin{array}{l}\text { Intensity } \\
\text { (VAS) }\end{array}$ & & & & & \\
\hline $\begin{array}{l}\text { Sullivan } \\
\text { et al. (2013) }\end{array}$ & $\mathrm{RCT}$ & $\begin{array}{l}17 \text { healthy and } \\
\text { recreationnaly } \\
\text { active }\end{array}$ & $\begin{array}{l}\text { Roller- } \\
\text { massager }\end{array}$ & Hamstrings & $\begin{array}{l}1-2 \times 5-10 \mathrm{~s} \\
120 \mathrm{bpm}\end{array}$ & $13 \mathrm{~kg}$ & No & Yes & $\begin{array}{l}\text { Foam rolling } \\
1 \text { set of } 5 \mathrm{~s} \\
2 \text { sets of } 5 \mathrm{~s} \\
1 \text { set of } 10 \mathrm{~s} \\
2 \text { sets of } 10 \mathrm{~s}\end{array}$ & SRBT & $\begin{array}{l}\uparrow \text { lower back and } \\
\text { hamstring flexibility } \\
\text { FR } 10 \text { s > FR } 5 \text { s }\end{array}$ \\
\hline $\begin{array}{l}\text { Halperin } \\
\text { et al. (2014) }\end{array}$ & $\mathrm{RC}$ & $\begin{array}{l}14 \text { healthy and } \\
\text { recreationnaly } \\
\text { active }\end{array}$ & $\begin{array}{l}\text { Roller- } \\
\text { massager }\end{array}$ & Plantarflexors & $\begin{array}{l}3 \times 30 \mathrm{~s} \\
30 \mathrm{bpm}\end{array}$ & 7/10 VAS & No & No & $\begin{array}{l}\text { Foam rolling } \\
\text { Static stretching }\end{array}$ & WBLT & $\begin{array}{l}\text { Both groups } \\
\uparrow \text { ankle dorsiflexion } \\
\text { ROM up to } 10 \text { min }\end{array}$ \\
\hline $\begin{array}{l}\text { Mohr et al. } \\
\text { (2014) }\end{array}$ & $\mathrm{RCT}$ & $\begin{array}{l}40 \text { subjects with } \\
\text { less than } 90^{\circ} \text { of } \\
\text { passive hip-flexion }\end{array}$ & Bio-foam roller & Hamstrings & $\begin{array}{l}3 \times 60 \mathrm{~s} \\
30 \mathrm{bpm}\end{array}$ & $\begin{array}{l}\text { Much pressure } \\
\text { as they could }\end{array}$ & $\begin{array}{l}1 \text { test } \\
\text { session }\end{array}$ & Yes & $\begin{array}{l}\text { Foam rolling } \\
\text { Static Stretching } \\
\text { Combined techniques } \\
3 \text { times/week over } \\
\text { 2-weeks }\end{array}$ & Passive SLR & $\begin{array}{l}\uparrow \text { hip ROM } \\
\text { Mixed group > FR and } \\
\text { SS group > control }\end{array}$ \\
\hline $\begin{array}{l}\text { Cho et al. } \\
\text { (2015) }\end{array}$ & $\mathrm{RCT}$ & $\begin{array}{l}50 \text { subjects with } \\
\text { hamstrings flexibility } \\
\text { deficit }\end{array}$ & $\begin{array}{l}\text { Wooden } \\
\text { triangle-shaped } \\
\text { pillow }\end{array}$ & Suboccipital & $1 \times 280 \mathrm{~s}$ & NR & NR & No & $\begin{array}{l}\text { Suboccipital muscle } \\
\text { inhibition }\end{array}$ & $\begin{array}{l}\text { Finger-floor } \\
\text { distance } \\
\text { SLR } \\
\text { Popliteal angle }\end{array}$ & $\uparrow$ hamstrings flexibility \\
\hline $\begin{array}{l}\text { Grieve et al. } \\
(2015)\end{array}$ & $\mathrm{RCT}$ & 24 healthy subjects & Tennis ball & Sole & $1 \times 120$ s/sole & $\begin{array}{l}\text { Much pressure } \\
\text { as they could }\end{array}$ & NR & Yes & Foam rolling & SRBT & $\begin{array}{l}\uparrow \text { hamstring and lower } \\
\text { back flexibility }\end{array}$ \\
\hline $\begin{array}{l}\text { Vigotsky } \\
\text { et al. (2015) }\end{array}$ & $\mathrm{RCT}$ & 23 healthy students & High density FR & Quadriceps & $2 \times 60$ s/Slowly & NR & NR & No & $\begin{array}{l}\text { Foam roller } \\
\text { Static stretching }\end{array}$ & $\begin{array}{l}\text { Modified Thomas } \\
\text { test }\end{array}$ & $\begin{array}{l}\uparrow \text { hip extension ROM } \\
\text { NS change knee flexion } \\
\text { NS change rectus } \\
\text { femoris length }\end{array}$ \\
\hline $\begin{array}{l}\text { Kelly and } \\
\text { Beardsley } \\
\text { (2016) }\end{array}$ & $\mathrm{RCT}$ & $\begin{array}{l}26 \text { healthy and } \\
\text { recreationnaly } \\
\text { active }\end{array}$ & High density FR & Plantar flexors & $\begin{array}{l}3 \times 30 \mathrm{~s} \\
15 \mathrm{bpm}\end{array}$ & $\begin{array}{l}\text { Much pressure } \\
\text { as they could }\end{array}$ & $\begin{array}{l}1 \text { test } \\
\text { session }\end{array}$ & Yes & $\begin{array}{l}\text { Foam rolling leg Control } \\
\text { leg }\end{array}$ & $\begin{array}{l}\text { WBLT pre- and } \\
\text { post- T0, T+5, 10, } \\
15,20 \mathrm{~min}\end{array}$ & $\begin{array}{l}\uparrow \text { dorsiflexion ROM } \\
\text { ipsilateral leg : up } \\
20 \text { min } \\
\text { contraletral leg : up } \\
10 \text { min }\end{array}$ \\
\hline $\begin{array}{l}\text { Patel et al. } \\
\text { (2016) }\end{array}$ & $\mathrm{RCT}$ & $\begin{array}{l}30 \text { subjects with } \\
\text { active knee } \\
\text { extension deficit }\end{array}$ & Tennis ball & Sole & $1 \times 120 \mathrm{~s} /$ foot & $\begin{array}{l}\text { Much pressure } \\
\text { as they could }\end{array}$ & NR & Yes & Foam rolling & $\begin{array}{l}\text { SRBT Active knee } \\
\text { extension }\end{array}$ & $\begin{array}{l}\uparrow \text { lower back and } \\
\text { hamstring flexibility }\end{array}$ \\
\hline $\begin{array}{l}\text { Boguszewski } \\
\text { et al. (2017) }\end{array}$ & $\mathrm{RCT}$ & $\begin{array}{l}37 \text { healthy and } \\
\text { recreationnaly } \\
\text { active }\end{array}$ & $\begin{array}{l}\text { Foam roller - } \\
\text { not reported }\end{array}$ & $\begin{array}{l}\text { Main lower limb } \\
\text { muscles }\end{array}$ & $\begin{array}{l}1 \times 20 \\
\mathrm{~min} / \mathrm{muscle}\end{array}$ & NR & Yes & Yes & $\begin{array}{l}\text { Foam rolling } \\
2 \text { times/week over } \\
\text { 8-weeks }\end{array}$ & $\begin{array}{l}\text { Single leg SRBT } \\
\text { Functional } \\
\text { Movement Screen } \\
\text { (FMS) }\end{array}$ & $\begin{array}{l}\uparrow \text { lower back and } \\
\text { hamstring flexibility vs } \\
\text { control group } \\
\uparrow \text { FMS score vs control } \\
\text { group }\end{array}$ \\
\hline
\end{tabular}


TABLE 6 | Continued

\begin{tabular}{|c|c|c|c|c|c|c|c|c|c|c|c|}
\hline \multirow{2}{*}{$\begin{array}{l}\text { Author } \\
\text { (year) }\end{array}$} & \multirow{2}{*}{$\begin{array}{l}\text { Study } \\
\text { design }\end{array}$} & \multirow[t]{2}{*}{ Sample } & \multicolumn{4}{|c|}{ Foam rolling intervention } & \multirow[b]{2}{*}{ Expertise } & \multirow[t]{2}{*}{ Control } & \multirow{2}{*}{$\begin{array}{l}\text { Others experimental } \\
\text { groups }\end{array}$} & \multirow{2}{*}{$\begin{array}{l}\text { Outcome } \\
\text { measures }\end{array}$} & \multirow[t]{2}{*}{ Effects } \\
\hline & & & Tool(s) & Targeted area & $\begin{array}{l}\text { Treatment } \\
\text { time and rate }\end{array}$ & $\begin{array}{l}\text { Intensity } \\
\text { (VAS) }\end{array}$ & & & & & \\
\hline $\begin{array}{l}\text { Garcia- } \\
\text { Gutiérrez } \\
\text { et al. (2017) }\end{array}$ & $\mathrm{RCT}$ & $\begin{array}{l}33 \text { healthy and } \\
\text { moderately active }\end{array}$ & $\begin{array}{l}\text { Vibrating FR } \\
\text { Non-vibrating } \\
\text { FR }\end{array}$ & $\begin{array}{l}\text { Plantar flexors - } \\
\text { dominant leg }\end{array}$ & $\begin{array}{l}5 \times 20 \mathrm{~s} \\
15 \mathrm{bpm}\end{array}$ & $\begin{array}{l}\text { Much pressure } \\
\text { as they could }\end{array}$ & $\begin{array}{l}1 \text { test } \\
\text { session }\end{array}$ & Yes & $\begin{array}{l}\text { Vibrating foam roller } \\
(32 \mathrm{~Hz} \text { ) Non-vibrating } \\
\text { foam roller }\end{array}$ & $\begin{array}{l}\text { WBLT } \\
\text { Maximal voluntary } \\
\text { contraction plantar } \\
\text { flexion/dorsiflexion } \\
\text { Both legs }\end{array}$ & $\begin{array}{l}\text { Both groups } \\
\uparrow \text { ankle ROM with a } \\
\text { crossover effect } \\
\text { NS difference between } \\
\text { groups } \\
\text { NS change strength }\end{array}$ \\
\hline $\begin{array}{l}\text { Grabow } \\
\text { et al. (2017) }\end{array}$ & $\mathrm{RCT}$ & $\begin{array}{l}12 \text { healthy and } \\
\text { recreationnaly } \\
\text { active }\end{array}$ & Foot roller & Sole & $\begin{array}{l}3 \times 60 \mathrm{~s} \\
30 \mathrm{bpm}\end{array}$ & 7/10 VAS & NR & No & $\begin{array}{l}\text { Foam rolling leg } \\
\text { Control leg }\end{array}$ & $\begin{array}{l}\text { Modified SRBT } \\
\text { WBLT }\end{array}$ & $\begin{array}{l}\text { NS change dorsiflexion } \\
\text { ROM } \\
\text { NS change lower and } \\
\text { hamstrings flexibility on } \\
\text { ipsilateral and } \\
\text { controlateral leg }\end{array}$ \\
\hline $\begin{array}{l}\text { Hsuan Su } \\
\text { et al. (2017) }\end{array}$ & $\mathrm{RC}$ & $\begin{array}{l}30 \text { college students } \\
\text { physically active }\end{array}$ & High density FR & $\begin{array}{l}\text { Quadriceps } \\
\text { and hamstrings }\end{array}$ & $3 \times 30 \mathrm{~s} /$ muscle & $\begin{array}{l}\text { Much pressure } \\
\text { as they could }\end{array}$ & $\begin{array}{l}1 \text { test } \\
\text { session }\end{array}$ & Yes & $\begin{array}{l}\text { Static stretching } \\
\text { Foam rolling } \\
\text { Dynamic stretching }\end{array}$ & $\begin{array}{l}\text { SRBT } \\
\text { Modified Thomas } \\
\text { test }\end{array}$ & $\begin{array}{l}\uparrow \text { quadriceps and } \\
\text { hamstring flexibility }\end{array}$ \\
\hline $\begin{array}{l}\text { Jung et al. } \\
\text { (2017) }\end{array}$ & $\mathrm{RC}$ & 22 healthy subjects & Wooden stick & $\begin{array}{l}\text { Suboccipital } \\
\text { region, } \\
\text { hamstrings and } \\
\text { sole }\end{array}$ & $\begin{array}{l}1 \times 4 \\
\mathrm{~min} / \text { muscle }\end{array}$ & NR & No & No & $\begin{array}{l}\text { Foam rolling } \\
\text { suboccipital } \\
\text { Foam rolling hamstrings } \\
\text { Foam rolling sole }\end{array}$ & SRBT & $\begin{array}{l}\text { Thrre groups } \\
\uparrow \text { lower and hamstrings } \\
\text { flexibility }\end{array}$ \\
\hline $\begin{array}{l}\text { Do et al. } \\
\text { (2018) }\end{array}$ & $\mathrm{RCT}$ & $\begin{array}{l}31 \text { healthy and } \\
\text { recreationnaly } \\
\text { active }\end{array}$ & $\begin{array}{l}\text { Micro foam } \\
\text { roller }\end{array}$ & Plantar fascia & $1 \times 5 \min$ & $\begin{array}{l}\text { Much pressure } \\
\text { as possible }\end{array}$ & NR & Yes & $\begin{array}{l}\text { Foam rolling } \\
\text { Sham group }\end{array}$ & $\begin{array}{l}\text { Toe touch test } \\
\text { Passive SLR }\end{array}$ & $\begin{array}{l}\uparrow \text { lower back and } \\
\text { hamstring flexibility }\end{array}$ \\
\hline $\begin{array}{l}\text { Killen et al. } \\
\text { (2018) }\end{array}$ & $\mathrm{RCT}$ & 23 healthy subjects & High density FR & Hamstrings & $\begin{array}{l}10 \times 30 \mathrm{~s} \\
30 \mathrm{bpm}\end{array}$ & NR & $\begin{array}{l}1 \text { test } \\
\text { session }\end{array}$ & No & $\begin{array}{l}\text { Static Stretching } \\
\text { Foam rolling on } \\
\text { dominant leg }\end{array}$ & SLR & $\begin{array}{l}\text { Both groups } \\
\uparrow \text { contralateral hip ROM }\end{array}$ \\
\hline $\begin{array}{l}\text { Madoni } \\
\text { et al. (2018) }\end{array}$ & RWS & $\begin{array}{l}22 \text { healthy and } \\
\text { recreationnaly } \\
\text { active }\end{array}$ & High density FR & Hamstrings & $3 \times 30 s$ & $\begin{array}{l}\text { Much pressure } \\
\text { as they could }\end{array}$ & $\begin{array}{l}1 \text { test } \\
\text { session }\end{array}$ & Yes & Foam rolling & SLR & $\uparrow$ hamstring flexibility \\
\hline $\begin{array}{l}\text { Phillips } \\
\text { et al. (2018) }\end{array}$ & $\mathrm{RC}$ & $\begin{array}{l}24 \text { healthy and } \\
\text { recreationally active }\end{array}$ & $\begin{array}{l}\text { Foam roller - } \\
\text { not reported }\end{array}$ & $\begin{array}{l}\text { Quadriceps, } \\
\text { plantar flexors }\end{array}$ & $\begin{array}{l}1 \times 60 \mathrm{~s} / \text { muscle } \\
10 \mathrm{bpm}\end{array}$ & $\begin{array}{l}\text { Much pressure } \\
\text { as they could }\end{array}$ & $\begin{array}{l}1 \text { test } \\
\text { session }\end{array}$ & Yes & $\begin{array}{l}\text { Foam rolling : } 60 \mathrm{~s} \\
\text { Foam rolling : } 5 \mathrm{~min} \\
\text { Planking on a heating } \\
\text { pad }\end{array}$ & Modified WBLT & $\begin{array}{l}\uparrow \text { dorsiflexion ROM } \\
\uparrow \text { quadriceps flexibility } \\
5 \text { min }>60 \text { s foam } \\
\text { rolling }\end{array}$ \\
\hline $\begin{array}{l}\text { Jeong et al. } \\
\text { (2019) }\end{array}$ & $\mathrm{RC}$ & 30 young women & Massage ball & Hamstrings & $3 \times 30$ s/zone & NR & NR & No & $\begin{array}{l}\text { Foam rolling } \\
\text { Self-stretching }\end{array}$ & $\begin{array}{l}\text { 90-90 SLR } \\
\text { pre- and post- } \\
\mathrm{T}+5,30 \mathrm{~min}\end{array}$ & $\begin{array}{l}\text { Both groups } \\
\uparrow R O M\end{array}$ \\
\hline
\end{tabular}


TABLE 6 | Continued

\begin{tabular}{|c|c|c|c|c|c|c|c|c|c|c|c|}
\hline \multirow{2}{*}{$\begin{array}{l}\text { Author } \\
\text { (year) }\end{array}$} & \multirow{2}{*}{$\begin{array}{l}\text { Study } \\
\text { design }\end{array}$} & \multirow[t]{2}{*}{ Sample } & \multicolumn{4}{|c|}{ Foam rolling intervention } & \multirow[b]{2}{*}{ Expertise } & \multirow[t]{2}{*}{ Control } & \multirow{2}{*}{$\begin{array}{l}\text { Others experimental } \\
\text { groups }\end{array}$} & \multirow{2}{*}{$\begin{array}{l}\text { Outcome } \\
\text { measures }\end{array}$} & \multirow[t]{2}{*}{ Effects } \\
\hline & & & Tool(s) & Targeted area & $\begin{array}{l}\text { Treatment } \\
\text { time and rate }\end{array}$ & $\begin{array}{l}\text { Intensity } \\
\text { (VAS) }\end{array}$ & & & & & \\
\hline $\begin{array}{l}\text { Lim and } \\
\text { Park (2019) }\end{array}$ & $\mathrm{RCT}$ & $\begin{array}{l}20 \text { healthy college } \\
\text { students }\end{array}$ & $\begin{array}{l}\text { Vibrating FR } \\
\text { Non-vibrating } \\
\text { FR }\end{array}$ & Hamstrings & $5 \times 60 s$ & NR & NR & No & $\begin{array}{l}\text { Vibrating foam roller } \\
(32 \mathrm{~Hz}) \\
\text { Non-vibrating foam } \\
\text { roller } \\
\text { Static stretching }\end{array}$ & $\begin{array}{l}\text { Active SLR } \\
\text { Active knee } \\
\text { extension test } \\
\text { CMJ }\end{array}$ & $\begin{array}{l}\text { Vibrating > non } \\
\text { vibrating FR } \\
\uparrow \text { hamstrings flexibility } \\
\text { NS change vertical } \\
\text { power }\end{array}$ \\
\hline $\begin{array}{l}\text { Pathania } \\
\text { and } \\
\text { Muragod } \\
\text { (2019) }\end{array}$ & $\mathrm{RCT}$ & $\begin{array}{l}45 \text { elderly subjects } \\
\text { with hamstring } \\
\text { flexibility deficit } \\
\text { (65-75 years of } \\
\text { age) }\end{array}$ & $\begin{array}{l}\text { High density } \\
\text { FRM2T blade }\end{array}$ & Hamstrings & $\begin{array}{l}2-3 \times 100- \\
150 \mathrm{~s}\end{array}$ & NR & NR & No & $\begin{array}{l}\text { Foam rolling (FR) } \\
\text { Static stretching (SS) } \\
\text { Instrument assisted soft } \\
\text { tissue moblization } \\
\text { (IASTM) } \\
3 \text { times/week over } \\
\text { 4-weeks }\end{array}$ & $\begin{array}{l}\text { Passive knee } \\
\text { extension } \\
\text { SRBT }\end{array}$ & $\begin{array}{l}\uparrow \text { lower back and } \\
\text { hamstring flexibility } \\
\text { IASTM }>\text { FR }>\text { SS }\end{array}$ \\
\hline $\begin{array}{l}\text { Smith et al. } \\
\text { (2019) }\end{array}$ & $\mathrm{RCT}$ & $\begin{array}{l}44 \text { healthy and } \\
\text { recreationnaly } \\
\text { active }\end{array}$ & High density FR & Plantar flexors & $\begin{array}{l}3 \times 30 \mathrm{~s} \\
60 \mathrm{bpm}\end{array}$ & NR & NR & No & $\begin{array}{l}\text { Foam rolling } \\
\text { Static Stretching } \\
\text { Foma rolling + Static } \\
\text { stretching }\end{array}$ & $\begin{array}{l}\text { Ankle dorsifleixon } \\
\text { ROM } \\
\text { pre- and } \\
\text { post-session } 1 \text {, } \\
\text { post- } T+3,6,7 \\
\text { weeks }\end{array}$ & $\begin{array}{l}\text { Three groups } \\
\uparrow \text { dorsiflexion ROM } \\
\text { No synergic effect of } \\
\text { FR and SS }\end{array}$ \\
\hline $\begin{array}{l}\text { Somers } \\
\text { et al. (2019) }\end{array}$ & $\mathrm{RCT}$ & $\begin{array}{l}42 \text { physical therapy } \\
\text { students }\end{array}$ & $\begin{array}{l}\text { Foam roller - } \\
\text { not reported }\end{array}$ & Calves & $2 \times 60$ s/Slowly & NR & NR & No & $\begin{array}{l}\text { Foam rolling alone } \\
\text { Dynamic stretch alone } \\
\text { Foam rolling + dynamic } \\
\text { stetch }\end{array}$ & WBLT & $\begin{array}{l}\text { NS change in ankle } \\
\text { ROM }\end{array}$ \\
\hline $\begin{array}{l}\text { Williams } \\
\text { and Selkow } \\
\text { (2019) }\end{array}$ & $\mathrm{RC}$ & $\begin{array}{l}15 \text { healthy } \\
\text { collegiate students }\end{array}$ & $\begin{array}{l}\text { High density } \\
\text { FR } \\
\text { Lacrosse ball }\end{array}$ & $\begin{array}{l}\text { Sole and } \\
\text { hamstrings }\end{array}$ & $\begin{array}{l}1 \times 120 \mathrm{~s} / \mathrm{muscle} \\
60-90 \mathrm{bpm}\end{array}$ & $\begin{array}{l}\text { As much } \\
\text { pressure as } \\
\text { they could }\end{array}$ & NR & No & $\begin{array}{l}\text { Sole rolling } \\
\text { Hamstrings foam } \\
\text { Sole and hamstrings } \\
\text { rolling }\end{array}$ & SRBT & $\begin{array}{l}\text { Three techniques } \\
\uparrow \text { lower back and } \\
\text { hamstring flexibility } \\
\text { equally }\end{array}$ \\
\hline
\end{tabular}

RC, randomized crossover; RCT, randomized controlled trial; FR, foam roller; NR, not reported; bpm, beats per minute; $\uparrow$ indicates increase; $\downarrow$ indicates decrease; SRBT, sit-and-reach box test; WBLT, weightbearing lunge test; SLR, straigth leg raise; NS, not significant. 
TABLE 7 | The effects of foam rolling on neurophysiological and physiological variables.

\begin{tabular}{|c|c|c|c|c|c|c|c|c|c|c|}
\hline \multirow{2}{*}{$\begin{array}{l}\text { Author } \\
\text { (year) }\end{array}$} & \multirow{2}{*}{$\begin{array}{l}\text { Study } \\
\text { design }\end{array}$} & \multirow[t]{2}{*}{ Sample } & \multicolumn{4}{|c|}{ Foam rolling intervention } & \multirow[t]{2}{*}{ Control } & \multirow{2}{*}{$\begin{array}{l}\text { Others experimental } \\
\text { groups }\end{array}$} & \multirow{2}{*}{$\begin{array}{l}\text { Outcome } \\
\text { measures }\end{array}$} & \multirow[t]{2}{*}{ Effects } \\
\hline & & & Tool(s) & Targeted area & $\begin{array}{l}\text { Treatment } \\
\text { time and rate }\end{array}$ & Intensity & & & & \\
\hline \multicolumn{11}{|c|}{ Neurophysiological and physiological effects } \\
\hline $\begin{array}{l}\text { Martínez- } \\
\text { Cabrera } \\
\text { and Núñez- } \\
\text { Sánchez } \\
\text { (2016) }\end{array}$ & $\mathrm{RCT}$ & $\begin{array}{l}7 \text { professional } \\
\text { soccer players }\end{array}$ & High density FR & Rectus femoris & $\begin{array}{l}4 \times 15 \mathrm{~s} \\
30 \mathrm{bpm}\end{array}$ & $N R$ & No & $\begin{array}{l}\text { Foam rolling leg } \\
\text { Control leg }\end{array}$ & $\begin{array}{l}\text { Muscle contractile } \\
\text { properties (TMG) }\end{array}$ & $\begin{array}{l}\text { Maintains muscle } \\
\text { contractile properties }\end{array}$ \\
\hline $\begin{array}{l}\text { Murray } \\
\text { et al. (2016) }\end{array}$ & $\mathrm{RC}$ & 12 squash players & High density FR & Quadriceps & $\begin{array}{l}1 \times 60 \mathrm{~s} \\
30 \mathrm{bpm}\end{array}$ & NR & Yes & $\begin{array}{l}\text { Foam rolling leg } \\
\text { Control leg }\end{array}$ & $\begin{array}{l}\text { Muscle contractile } \\
\text { properties (TMG) } \\
\text { Superficial } \\
\text { temperature }\end{array}$ & $\begin{array}{l}\text { NS change muscle } \\
\text { contractile properties } \\
\text { NS change skin } \\
\text { temperature }\end{array}$ \\
\hline $\begin{array}{l}\text { Casanova } \\
\text { et al. (2017) }\end{array}$ & $\mathrm{RC}$ & 10 athletes & $\begin{array}{l}\text { Roller } \\
\text { massager }\end{array}$ & Plantar flexors & $\begin{array}{l}6 \times 45 \mathrm{~s} \\
30 \mathrm{bpm}\end{array}$ & NR & Yes & $\begin{array}{l}\text { Foam rolling leg } \\
\text { Control leg }\end{array}$ & $\begin{array}{l}\text { Muscle oxygenation } \\
\text { (HHb } \\
\text { concentration) } \\
\text { Muscle morphology }\end{array}$ & $\begin{array}{l}\text { NS change muscle } \\
\text { oxygenation } \\
\text { NS change muscle } \\
\text { morphology }\end{array}$ \\
\hline $\begin{array}{l}\text { D'Amico } \\
\text { and } \\
\text { Paolone } \\
\text { (2017) }\end{array}$ & $\mathrm{RC}$ & 16 trained males & High density FR & $\begin{array}{l}\text { Main lower limb } \\
\text { muscles per leg }\end{array}$ & $\begin{array}{l}1 \times 30 \mathrm{~s} / \text { muscle } \\
6 \mathrm{bpm}\end{array}$ & NR & Yes & Foam rolling & $\begin{array}{l}\text { Blood sample } \\
\text { VCO2 } \\
\text { pre- and post- } \\
\text { each run }\end{array}$ & $\begin{array}{l}\text { NS change blood } \\
\text { lactate } \\
\text { concentration } \\
\text { NS change VCO2 }\end{array}$ \\
\hline $\begin{array}{l}\text { Kalén et al. } \\
\text { (2017) }\end{array}$ & $\mathrm{RC}$ & 12 surf lifeguards & High density FR & $\begin{array}{l}\text { Main lower limb } \\
\text { muscles per leg }\end{array}$ & $2 \times 60 s$ & $7 / 10$ & Yes & $\begin{array}{l}\text { Foam rolling } \\
\text { Running }\end{array}$ & Blood sample & $\begin{array}{l}\text { Both groups } \\
\uparrow \text { blood lactate } \\
\text { clearance }\end{array}$ \\
\hline $\begin{array}{l}\text { Beier et al. } \\
\text { (2019) }\end{array}$ & $\mathrm{RC}$ & $\begin{array}{l}11 \text { resistance } \\
\text { trained subjects }\end{array}$ & Stick massage & $\begin{array}{l}\text { Rectus femoris } \\
\text { and gluteus } \\
\text { maximus }\end{array}$ & $1 \times 120 \mathrm{~s} /$ muscle & $\begin{array}{l}\text { Heavy } \\
\text { pressure }\end{array}$ & No & $\begin{array}{l}\text { Foam rolling } \\
\text { Dynamic warmp-up }\end{array}$ & $\begin{array}{l}\text { Muscle activation } \\
\text { (EMGs) }\end{array}$ & $\begin{array}{l}\text { NS change muscle } \\
\text { activation }\end{array}$ \\
\hline $\begin{array}{l}\text { Mazzei } \\
\text { (2019) }\end{array}$ & $\mathrm{RCT}$ & $\begin{array}{l}15 \text { NCAA Division I } \\
\text { swimmers }\end{array}$ & $\begin{array}{l}\text { Vibrating FR } \\
\text { Non-vibrating } \\
\text { FR }\end{array}$ & Plantar flexors & $\begin{array}{l}3 \times 30 \mathrm{~s} \\
30 \mathrm{bpm}\end{array}$ & NR & No & $\begin{array}{l}\text { Vibrating foam rolling } \\
\text { (1200 to } 3600 \text { rpm) } \\
\text { Non-vibrating foam } \\
\text { rolling }\end{array}$ & $\begin{array}{l}\text { Muscle activation } \\
\text { (EMGs) }\end{array}$ & $\begin{array}{l}\text { Both groups } \\
\text { NS change muscle } \\
\text { activation }\end{array}$ \\
\hline $\begin{array}{l}\text { Kim et al. } \\
(2014)\end{array}$ & $\mathrm{RCT}$ & 22 healthy subjects & $\begin{array}{l}\text { FR-not } \\
\text { reported }\end{array}$ & $\begin{array}{l}\text { Main lower limb } \\
\text { muscles and } \\
\text { back }\end{array}$ & $1 \times 3-6 \min$ & $N R$ & Yes & Foam rolling & Blood sample & Both groups : $\downarrow$ cortisol \\
\hline
\end{tabular}


TABLE 7 | Continued

\begin{tabular}{|c|c|c|c|c|c|c|c|c|c|c|}
\hline \multirow{2}{*}{$\begin{array}{l}\text { Author } \\
\text { (year) }\end{array}$} & \multirow{2}{*}{$\begin{array}{l}\text { Study } \\
\text { design }\end{array}$} & \multirow[t]{2}{*}{ Sample } & \multicolumn{4}{|c|}{ Foam rolling intervention } & \multirow[t]{2}{*}{ Control } & \multirow{2}{*}{$\begin{array}{l}\text { Others experimental } \\
\text { groups }\end{array}$} & \multirow{2}{*}{$\begin{array}{l}\text { Outcome } \\
\text { measures }\end{array}$} & \multirow[t]{2}{*}{ Effects } \\
\hline & & & Tool(s) & Targeted area & $\begin{array}{l}\text { Treatment } \\
\text { time and rate }\end{array}$ & Intensity & & & & \\
\hline $\begin{array}{l}\text { Okamoto } \\
\text { et al. (2014) }\end{array}$ & $\mathrm{RC}$ & 10 healthy subjects & $\begin{array}{l}\text { Polystyrene } \\
\text { roller }\end{array}$ & $\begin{array}{l}\text { Main lower limb } \\
\text { muscles }\end{array}$ & $\begin{array}{l}20 \\
\text { repetition/muscle }\end{array}$ & NR & Yes & Foam rolling & $\begin{array}{l}\text { Arterial stiffness } \\
\text { Blood sample }\end{array}$ & $\begin{array}{l}\downarrow \text { brachial-ankle pulse } \\
\text { wave velocity } \\
\uparrow \text { vasoactive substance } \\
\text { ( } \uparrow \text { nitric oxide } \\
\text { concentration) }\end{array}$ \\
\hline $\begin{array}{l}\text { Thistlethwaite } \\
\text { et al. (2016) }\end{array}$ & $\begin{array}{l}\text { Pilot } \\
\text { test }\end{array}$ & 6 subjects & PVC pipe & $\begin{array}{l}\text { lliotibial band, } \\
\text { adductors, } \\
\text { hamstrings, } \\
\text { quadriceps) }\end{array}$ & $1 \times 180 \mathrm{~s} /$ muscle & NR & No & $\begin{array}{l}\text { Foam rolling } \\
3 \text { times/week over } 6 \\
\text { weeks }\end{array}$ & Endothelial function & $\begin{array}{l}\uparrow \text { blood flow } \\
\text { ( } \text { diameter of the } \\
\text { femoral artery) }\end{array}$ \\
\hline $\begin{array}{l}\text { Ginszt et al. } \\
(2017)\end{array}$ & $\begin{array}{l}\text { Pilot } \\
\text { test }\end{array}$ & 20 healthy adults & High density FR & $\begin{array}{l}\text { Right } \\
\text { quadriceps }\end{array}$ & $1 \times 60 s$ & $\begin{array}{l}\text { Much } \\
\text { pressure as } \\
\text { they could }\end{array}$ & No & $\begin{array}{l}\text { Foam rolling leg } \\
\text { Control leg }\end{array}$ & $\begin{array}{l}\text { Muscle activation } \\
\text { (EMGs) }\end{array}$ & $\downarrow$ muscle fatigue \\
\hline $\begin{array}{l}\text { Hotfiel et al. } \\
\text { (2017) }\end{array}$ & RCT & 21 healthy students & High density FR & lliotibial band & $3 \times 45 s$ & $\begin{array}{l}\text { Much } \\
\text { pressure as } \\
\text { they could }\end{array}$ & No & Foam rolling & $\begin{array}{l}\text { Arterial tissue } \\
\text { perfusion post- T0, } \\
T+30 \text { min }\end{array}$ & $\begin{array}{l}\uparrow \text { arterial blood flow up } \\
\text { to } 30 \mathrm{~min}\end{array}$ \\
\hline $\begin{array}{l}\text { Romero- } \\
\text { Moraleda } \\
\text { et al. (2017) }\end{array}$ & $\mathrm{RCT}$ & $\begin{array}{l}33 \text { healthy and } \\
\text { moderately active }\end{array}$ & High density FR & Quadriceps & $5 \times 60 s$ & $\begin{array}{l}\text { More of } \\
\text { their body } \\
\text { weight }\end{array}$ & No & $\begin{array}{l}\text { Foam rolling } \\
\text { Neurodynamic } \\
\text { mobilization }\end{array}$ & $\begin{array}{l}\text { Muscle activation } \\
\text { (EMGs) } \\
\text { MVIC knee } \\
\text { extension }\end{array}$ & $\begin{array}{l}\text { Both interventions : } \\
\uparrow \text { muscle activation } \\
\uparrow \text { muscle strength }\end{array}$ \\
\hline $\begin{array}{l}\text { Schroeder } \\
\text { et al. (2017) }\end{array}$ & $\mathrm{RC}$ & $\begin{array}{l}12 \text { heathly and } \\
\text { recreationnaly } \\
\text { active }\end{array}$ & High density FR & $\begin{array}{l}\text { Hamstrings, } \\
\text { gluteus, lower } \\
\text { back }\end{array}$ & $\begin{array}{l}3 \times 60 \mathrm{~s} \\
15 \mathrm{bpm}\end{array}$ & $\begin{array}{c}40,65 \\
75 \%\end{array}$ & No & $\begin{array}{l}\text { Weight training } \\
\text { Stretching } \\
\text { Foam rolling }\end{array}$ & $\begin{array}{l}\text { Muscle contractile } \\
\text { properties (TMG) }\end{array}$ & $\begin{array}{l}\text { NS change muscle } \\
\text { contractile properties }\end{array}$ \\
\hline $\begin{array}{l}\text { Hodgson } \\
\text { et al. (2018) }\end{array}$ & $\mathrm{RCT}$ & $\begin{array}{l}23 \text { healthy and } \\
\text { recreationally active }\end{array}$ & $\begin{array}{l}\text { Roller } \\
\text { massager }\end{array}$ & $\begin{array}{l}\text { Quadriceps } \\
\text { and hamstrings }\end{array}$ & $\begin{array}{l}4 \times 30 \mathrm{~s} / \text { muscle } \\
60 \mathrm{bpm}\end{array}$ & $7 / 10$ & Yes & $\begin{array}{l}\text { High frequencies } \\
\text { ( } 6 \text { times /week) } \\
\text { Low frequencies } \\
\text { (3 times/week) } \\
\text { over 4-weeks }\end{array}$ & $\begin{array}{l}\text { Muscle activation } \\
\text { (EMGs) } \\
\text { Knee flexors, } \\
\text { extensors MVIC }\end{array}$ & $\begin{array}{l}\text { NS change muscle } \\
\text { activation } \\
\text { NS change muscle } \\
\text { strength }\end{array}$ \\
\hline $\begin{array}{l}\text { Lastova } \\
\text { et al. (2018) }\end{array}$ & $\mathrm{RCT}$ & $\begin{array}{l}15 \text { healthy and } \\
\text { recreationnaly } \\
\text { active }\end{array}$ & High density FR & $\begin{array}{l}\text { Main lower limb } \\
\text { muscles and } \\
\text { lower/upper } \\
\text { back }\end{array}$ & $\begin{array}{l}1 \times 40 \mathrm{~s} \\
15 \mathrm{bpm}\end{array}$ & NR & Yes & Foam rolling & $\begin{array}{l}\text { Blood pressure } \\
\text { Heart rate variability } \\
\text { pre and post- } \mathrm{T0}, \\
\mathrm{T}+10, \mathrm{~T}+30 \mathrm{~min}\end{array}$ & $\begin{array}{l}\downarrow \text { blood pressure at } 10 \\
\text { and } 30 \text { min } \\
\downarrow \text { sympathovagal } \\
\text { balance at } 30 \mathrm{~min}\end{array}$ \\
\hline
\end{tabular}


TABLE $7 \mid$ Continued

\begin{tabular}{|c|c|c|c|c|c|c|c|c|c|c|}
\hline \multirow{2}{*}{$\begin{array}{l}\text { Author } \\
\text { (year) }\end{array}$} & \multirow{2}{*}{$\begin{array}{l}\text { Study } \\
\text { design }\end{array}$} & \multirow[t]{2}{*}{ Sample } & \multicolumn{4}{|c|}{ Foam rolling intervention } & \multirow[t]{2}{*}{ Control } & \multirow{2}{*}{$\begin{array}{l}\text { Others experimental } \\
\text { groups }\end{array}$} & \multirow{2}{*}{$\begin{array}{l}\text { Outcome } \\
\text { measures }\end{array}$} & \multirow[t]{2}{*}{ Effects } \\
\hline & & & Tool(s) & Targeted area & $\begin{array}{l}\text { Treatment } \\
\text { time and rate }\end{array}$ & Intensity & & & & \\
\hline $\begin{array}{l}\text { Macgregor } \\
\text { et al. (2018) }\end{array}$ & $\mathrm{RC}$ & $\begin{array}{l}16 \text { healthy } \\
\text { recreationally active } \\
\text { males }\end{array}$ & High density FR & Quadriceps & $\begin{array}{l}1 \times 120 \mathrm{~s} \\
60 \mathrm{bpm}\end{array}$ & $6 / 10$ & Yes & $\begin{array}{l}\text { Foam rolling } \\
\text { over } 3 \text { consecutive } \\
\text { days }\end{array}$ & $\begin{array}{l}\text { Muscle activation } \\
\text { (EMGs) } \\
\text { Muscle contractile } \\
\text { properties (TMG) }\end{array}$ & $\begin{array}{l}\downarrow \text { muscle activity } \\
\uparrow \text { muscle displacement }\end{array}$ \\
\hline $\begin{array}{l}\text { Madoni } \\
\text { et al. (2018) }\end{array}$ & $\mathrm{RCT}$ & $\begin{array}{l}22 \text { healthy and } \\
\text { recreationnaly } \\
\text { active }\end{array}$ & High density FR & Hamstrings & $3 \times 30 s$ & $\begin{array}{l}\text { Much } \\
\text { pressure as } \\
\text { they could }\end{array}$ & Yes & Foam rolling & $\begin{array}{l}\text { Muscle activation } \\
\text { (EMGs) } \\
\text { Maximal knee } \\
\text { extension/flexion }\end{array}$ & $\begin{array}{l}\text { NS change muscle } \\
\text { activation } \\
\text { NS change strength } \\
\text { ratio }\end{array}$ \\
\hline $\begin{array}{l}\text { Capobianco } \\
\text { et al. (2019) }\end{array}$ & $\mathrm{RC}$ & $\begin{array}{l}30 \text { young and } \\
\text { middle-aged adults }\end{array}$ & Therapy ball & Calf & $\begin{array}{l}3 \times 60 \mathrm{~s} / \mathrm{leg} \\
15 \mathrm{bpm}\end{array}$ & $\begin{array}{c}>5 / 10 \\
\text { (discomfort } \\
\text { level) }\end{array}$ & No & $\begin{array}{l}\text { Static stretching } \\
\text { Foam rolling + static } \\
\text { stretching }\end{array}$ & $\begin{array}{l}\text { Muscle activation } \\
\text { (EMGs) } \\
\text { Subcutaneous } \\
\text { tissue thickness }\end{array}$ & $\begin{array}{l}\uparrow \text { muscle activation } \\
\text { (foam rolling > static } \\
\text { stretching) } \\
\text { NS change } \\
\text { subcutaneous tissue } \\
\text { thickness }\end{array}$ \\
\hline $\begin{array}{l}\text { Kim et al. } \\
\text { (2019) }\end{array}$ & $\mathrm{RC}$ & $\begin{array}{l}30 \text { participants with } \\
\text { neck pain (age: } \\
65.9 \pm 3.4 \text { years) }\end{array}$ & $\begin{array}{l}\text { Soft inflatable } \\
\text { rubber ball } \\
\text { Hard massage } \\
\text { ball }\end{array}$ & $\begin{array}{l}\text { Suboccipital } \\
\text { region }\end{array}$ & $1 \times 10$ secs & $N R$ & Yes & $\begin{array}{l}\text { Soft inflatable rubber } \\
\text { ball } \\
\text { Hard massage ball }\end{array}$ & $\begin{array}{l}\text { Muscle activation } \\
\text { (EMGs) } \\
\text { Radiography } \\
\text { (compressed soft } \\
\text { tissue thickness } \\
\text { and neck extension } \\
\text { ROM) }\end{array}$ & $\begin{array}{l}\text { Soft inflatable rubber } \\
\text { ball vs hard massage } \\
\text { ball } \\
\text { Less muscle activity } \\
\text { (less muscle tension) } \\
\text { Less compressed soft } \\
\text { tissue thickness }\end{array}$ \\
\hline $\begin{array}{l}\text { Ye et al. } \\
\text { (2019) }\end{array}$ & $\mathrm{RC}$ & $\begin{array}{l}34 \text { healthy and } \\
\text { physically active }\end{array}$ & High density FR & Hamstrings & $\begin{array}{l}10 \times 30 \mathrm{~s} \\
30 \mathrm{bpm}\end{array}$ & NR & Yes & Yes & $\begin{array}{l}\text { Muscle activation } \\
\text { (EMGs) } \\
\text { Knee flexors MVIC }\end{array}$ & $\begin{array}{l}\text { NS change muscle } \\
\text { activity and strength }\end{array}$ \\
\hline
\end{tabular}

$R C$, randomized crossover; $R C T$, randomized controlled trial; $F R$, foam roller; NR, not reported; bpm, beats per minute; $\uparrow$ indicates increase; $\downarrow$ indicates decrease; MVIC, maximal voluntary isometric contraction; EMGs, surface electromyography; TMG, tensiomyography; NS, not significant. 
Romero-Moraleda et al., 2017; Table 5). Regardless the tools' use, a foam roller, a massage stick, golf or tennis balls, the FR intervention yielded immediate flexibility and ROM gains (Cheatham et al., 2015; Grieve et al., 2015; Brengesjö and Lohaller, 2017; Monteiro et al., 2017, 2019). Foam roller and roller massager, for instance, were shown to elicit comparable increased ROM (Monteiro et al., 2017, 2019). This effect would be reinforced by few additional degrees with vibrating foam rollers. Frequencies between 33 and $62 \mathrm{~Hz}$ would guarantee higher ROM and PPT elevations, compared to a non-vibrating foam roller (Cheatham et al., 2017, 2019; Han et al., 2017; Table 4). In addition, ROM benefits would depend on a dose-response effect of FR (120 vs. 60 s) (Monteiro et al., 2017, 2019). More surprisingly, FR would also demonstrate the ability to have a delocalized effect. For example, FR of sole or hamstring muscles might positively influence lower back and hamstring flexibility by improving the sit-and-reach test scores, with a wooden stick or a tennis ball (Grieve et al., 2015; Jung et al., 2017; Table 6).

The most supported hypothesis to explain these changes would be a modification of the autonomic nervous system responses (Joshi et al., 2018; Dębski et al., 2019; Wiewelhove et al., 2019). The slow deep pressure would induce a decrease in the tone of related skeletal motor units by stimulating mechanoreceptors. This chain reaction would elicit a parasympathetic-dominant neurophysiological state, thus eliciting a greater relaxation (Schleip, 2003b). Mechanical pressure applied during FR would elicit similar effect. For example, in participants with rounded shoulder, both trapezius and pectoralis major muscles activity decreased after a FR intervention. This progress was accompanied by a reduction in shoulder height (Choi, 2019). These findings represent a useful source of information to guide FR practitioners. Indeed, local FR treatment therefore does not seem to be limited to a single element, but may impact all surrounding structures, even the whole body. This particularity represents a particular interest for physiotherapists to correct certain postural imbalances and/or muscular flexibility deficit.

Commonly used to improve ROM, FR has also been tested during warm-up to improve the physical qualities of athletes such as muscle power, strength or agility. However, unlike ROM, performance results obtained were not always clearly established (Burk et al., 2019; Hughes and Ramer, 2019; Skinner et al., 2020). Some studies recorded improvements in muscle power, strength or agility, after a single session of FR (D'Andrea, 2016; Sağiroğlu, 2017; Stroiney et al., 2020). Other came to different conclusions. For example, FR was not shown to bring any significant improvement in performance (Burk et al., 2019). Few protocols have been tested and replicated enough to lead to real consensus. Indeed, between the protocols, many parameters differed such as outcome measures, FR tool, target muscles, type of population, participants' FR experience, and FR instructions (e.g., pressure level, duration and rate of treatment) (Burk et al., 2019; Dębski et al., 2019). It is likely that this experimental disparity justifies the heterogeneity of the results reported in the literature. Until a reliable consensus is reached, the use of FR for warm-up should certainly not be contraindicated. In fact, unlike static stretching, there was no loss of physical capacity
(Halperin et al., 2014; Bradley et al., 2016; Grabow et al., 2017; Su et al., 2017).

For the same reasons of reproducibility and the lack of sufficient data, effects of post-training FR on physiological markers remain inconclusive. In laboratory conditions, excluding physical exertion, first results revealed a decrease in brachialankle pulse wave velocity (from $1202 \pm 105$ to $1074 \pm 110 \mathrm{~cm} / \mathrm{s}$ ) and an increase in plasma nitric oxide concentrations (from $20.4 \pm 6.9$ to $34.4 \pm 17.2 \mu \mathrm{mol} / \mathrm{L}$ ), reflecting an improvement in endothelial functions and arterial stiffness (Okamoto et al., 2014). Another study also observed an increase in the arterial blood flow. Compared to a baseline recording, the mean peak flow increased of $73.6 \%$ immediately after FR and $52.7 \% 30$ min posttreatment (Hotfiel et al., 2017). The drop in blood pressure was also observed up to $30 \mathrm{~min}$ after FR, confirming the hypothesis of a positive effect of FR on cardiovascular protective effect and health (Lastova et al., 2018; Table 7). In training conditions, FR has been shown to be ineffective on the muscular re-oxygenation in the treated leg after a bilateral exercise inducing muscular damage (Casanova et al., 2017). Some indirect markers such as cortisol and lactate confirmed, by their fall, this positive influence of FR on blood circulation (Kim et al., 2014; Kalén et al., 2017). In conclusion, comparison of results between studies is delicate due to the singular nature of each experiment, increasing the difficulty of interpreting certain acute effects which are still undecided. Indeed, few protocols have been reproduced and sufficiently tested to establish a consensus and therefore an optimal FR program. In response to this uncertainty, two recent systematic reviews of literature proposed a framework to guide practitioners and researchers for future experiments (Dębski et al., 2019; Hendricks et al., 2019). According to these authors, acute effects identifiable by gains in ROM, increase in the PPT, reduction in DOMS, or even better vascular function, would be made possible by respecting certain rules of practice. It would therefore be wise for FR tool users to repeat each exercise 1-3 times at a rate of $20 \mathrm{bpm}$. A set of rolling should last between 30 and $120 \mathrm{~s}$ and followed by a $30 \mathrm{~s}$ recovery period. Pressure, on the other hand, has an individual character and a part of subjectivity. However, the application force should not exceed the pain tolerance threshold. On a pain scale, a $7 / 10$ indicator or the following instruction, "as large as possible" is commonly used to guide practitioners for pressure (Dębski et al., 2019; Hendricks et al., 2019). FR tools, such as foam roller, roller massager or ball, should therefore be firm enough (Cheatham et al., 2015), and ischemic pressure is advised on sensitive areas until a feeling of release is obtained (Dębski et al., 2019; Hendricks et al., 2019). To complete this information, we argue that two additional parameters should be taken. To begin with, user experience in the practice of FR is required as FR requires some experience to master the level of pressure on the tool. Poor management can elicit excessive discomfort or pain, and bias the effects of FR technique. The second determining criterion is the number of areas treated. It seems that the effects of FR are short-lived, 10-20 min depending on the studies (MacDonald et al., 2013; Halperin et al., 2014; Jay et al., 2014; Škarabot et al., 2015; Kelly and Beardsley, 2016). It is therefore essential to ensure the effective duration of the routine so as not 
to exceed this period and risk seeing the effects dissipate in the first target areas.

\section{Long-Term Interventions}

The effects of FR were investigated within a span of several days or weeks. The paradigms either involved the follow-up of the effects of FR after a single session, or administered regular FR sessions along the intervention period. Protocols usually involved 2-5 sessions per week delivered within a span of 3-8 weeks. The use of a ball or foam roller demonstrated its usefulness for improving shoulder, knee, or ankle ROM (Le Gal et al., 2018; Smith et al., 2019), without harmful consequences on physical performance (Hodgson et al., 2019). Regular combination of FR and static stretching may have an additional effect for increasing ROM (Mohr et al., 2014; Škarabot et al., 2015). The effects of FR may be due to neural changes, the pressure exerting on the soft tissues increasing the tolerance to stretching, and therefore promoting performance gains (Škarabot et al., 2015).

With regard to vascular function, delayed beneficial effects were observed for a frequency of three FR sessions per week during a 6-week period (Thistlethwaite et al., 2016). A drop in blood pressure, heart rate variability, and sympathovagal balance, has also been reported (Chan et al., 2015; Lastova et al., 2018). Although this is premature to draw any firm conclusion, FR therefore appears effective to stimulate the organism and maintain better health.

\section{Procedures}

FR techniques involve two main maneuvers which can be combined in a single routine. The pressure depends on the tool used, its density, and the target area (Miller and Rockey, 2006; Sullivan et al., 2013; Cheatham et al., 2015). Few studies recorded the pressure applied during FR with a specific designed constant pressure roller apparatus. Two experiments measured muscle strength and flexibility after a continuous pressure of $13 \mathrm{~kg}$ on the hamstrings (Sullivan et al., 2013), as well as $20 \mathrm{~kg}$ on the quadriceps, with roller massager (Bradbury-Squires et al., 2014). However, with a foam roller, these values usually range from 27 to $68 \%$ of the body weight, depending on the muscle and the position (e.g., bilateral, unilateral) of the participants (MacDonald et al., 2013; Murray et al., 2016; Macgregor et al., 2018; Baumgart et al., 2019). Research remains sparse on pressure level, and no specific value is recommended. However, the literature demonstrated the existence of a dose-dependent response to FR. Some authors reported a significant improvement between two treatments of different durations (Bradbury-Squires et al., 2014; Monteiro et al., 2017,a; Phillips et al., 2018), whereas others did not corroborate an effect of the routine duration (Sullivan et al., 2013; Guillot et al., 2019; Table 6). Despite divergent results on its optimal use, FR practice systematically resulted in improved ROM and PPT (Jay et al., 2014; Cavanaugh, 2016; Kelly and Beardsley, 2016; Casanova et al., 2017; Cheatham and Baker, 2017; Garcia-Gutiérrez et al., 2018; Killen et al., 2018), trending approach consisting in the combination of active joint mobilization (e.g., knee flexion-extension movement) with FR practice (Cheatham and Baker, 2017; Cheatham et al., 2017, 2019; Cheatham and Kolber, 2018; Cheatham and Stull, 2018a,b;
Table 4). Such combination provided promising early effects on ROM gains (Cheatham et al., 2017; Han et al., 2017).

For safe and effective FR interventions, literature-driven guidelines should now be outlined and conceptualized. Quantifying the biomechanical workload applied through the FR routine is of critical importance. While higher mechanical compressions on the underlying tissues might be exerted using FR, compared to MMs, a potentially harmful impact on connective tissues, nerves, vessels and bones, should not be excluded. Deleterious effects must be controlled in future designs (Fleckenstein et al., 2017). External biomechanical loads should also be quantified to determine to which extent FR differs from $\mathrm{MM}$ in terms of pressures. Regular practice might be more suitable than longer session durations. Prolonged FR beyond 90 $s$ of treatment in the same area might not bring any additional benefit (Monteiro et al., 2017a), and excess may even cause harmful effects. Eventually, practitioners should certainly adjust FR practice to their own sensations. For instance, PPT should never be exceeded to prevent injuries.

\section{MANUAL MASSAGE AND FOAM ROLLING AT THE SCOPE OF MOTOR CONTROL FRAMEWORKS}

\section{From Resemblance to Dissimilarity}

MM and FR are both likely to positively affect psychometric, behavioral and physiological variables. As mentioned in the previous sections, experimental data extensively confirmed their respective beneficial effects. The same organs and tissues are targeted by both techniques, which might account for the congruent pattern of beneficial results on well-being and motor performance. Furthermore, both techniques appeared to promote motor recovery, with similar body effects during warm-up and post-exercise recovery. They are associated with increased well-being and give the opportunity to temporarily improve ROM and PPT, without altering physical performance (i.e., power, strength, agility). In practice, however, MM and FR are highly distinct. During MM, athletes have no control over the massage parameters, whereas during FR, they produce voluntary movements to complete the routine, by regulating the level of pressure exerted and the speed of execution. While this may be considered an advantage inherent to the technique, the lack of standardization of FR protocols represents an obstacle to the development of clinical applications. Indeed, the few existing guidelines do not provide medical professionals the necessary levels of reproducibility and reliability for application of such routines in clinical populations (Cheatham et al., 2015; Schroeder and Best, 2015). Classically, a MM lasts between 15 and $30 \mathrm{~min}$ (Standley et al., 2010), compared to 30-120 s per muscle group for FR. This difference is explained by the more holistic approach of the body during MM. More muscle groups are manually massaged, and several techniques can be used in a single area, hence increasing the whole duration of treatment. Conversely, in most FR studies, one or two muscle groups are mainly involved for 30-120 s each (Dębski et al., 2019). 


\section{Motor Control Implications}

There is currently no hypothesis or conceptual approach that distinguishes MM from FR, even though a fundamental distinction between the two types of massaging interventions stems from the nature of their requirements in terms of motor control strategies. The person receiving a MM remains passive, lying on the massage table, usually in dorsal or ventral decubitus. The routine and the pressures derive from the physiotherapists' experience and available sensory feedback from the MM routine or provided by the patient. The gestures of the physiotherapist cannot be anticipated by the person, thus resulting in a retroactive mode of action control with an ongoing central integration of proprioceptive feedback (Hasegawa et al., 2001). Although the participant can adjust muscle tone at his convenience, he is primarily confronted with a retroactive mode of action control (Braver, 2012). Conversely, while performing FR, the person directly exerts pressures through voluntary actions to manipulate the massaging tool. FR thus requires a predominant proactive mode of action control, where proactive operations of forward and inverse modeling, which do not require sensory feedback from the periphery, are involved (Cervin et al., 2002). Although with tools such as balls or foam roller, where the individual simply uses the body weight to achieve the desired effects, it remains a comparable proactive mode of action control. If necessary, the person always has the possibility to use retroactive operations to adjust FR parameters. Contrary to $\mathrm{MM}$, the sensory consequence of voluntary motor commands during FR can therefore be anticipated by means of the efferent copy derived from the forward model that associates motor commands with their sensory consequences. According to the dual mechanisms of motor control framework (Braver, 2012), MM and FR can thus be distinguished by the implementation of two distinct motor control strategies. These two interventions, with opposite modes of action, do not seem to offer any compromise. The user is unable to migrate from one mode of action to another. Interestingly, this limit could be easily resolved with technological advances and the appearance of collaborative robots. By its unique functionalities, this new generation of robot might conceptually reconcile the opposition of MM and FR. Indeed, the autonomy and real-time interaction capabilities of these robots with the user offer new perspectives in terms of motor control that have yet to be explored.

\section{ROBOTIC MASSAGE: AN EMERGING PARADIGM}

\section{The Instrumentalization of Massage}

To the best of our knowledge, there is yet no massage technique allowing for an actual combination of the retroactive and proactive modes of action control. The advent of intelligent robotic massage might contribute to integrate these two types of motor control within single massaging routines, and therefore provide a unique and complete approach to the massage experience. Spurred by an economic purpose, and to overcome limits of human faculties, several assisting devices offering massage programs are already available in beauty salons and physiotherapists' offices (e.g., LPG endermologie ${ }^{\circledR}, \mathrm{H} 2 \mathrm{O}$ Body system ${ }^{\circledR}$, wellsystem ${ }^{\mathrm{TM}}$ ). Such devices offer a relevant alternative to the MM, due to the fatigue of the physiotherapist, and the loss of efficiency resulting from repetitive practice. Accordingly, many professionals suffer from pathologies such as musculoskeletal disorder due to the amount of exposure to repeated uncomfortable postures, maneuvers and manipulations (Albert et al., 2008; Murali et al., 2014; Rossettini et al., 2016). Another strength of robotic devices delivering massages is the opportunity to homogenize massage techniques, such as the palpate-rolling in the context of anticellulite (Xiaoqin and Yonggen, 2010; Mezencevová et al., 2017). In the case of a purely robotic massage routine, participants for now remain in a passive situation, and thus exclusively engage retroactive modes of action control. Despite obvious advantages, first robotic devices failed to provide interactivity options of users toward the system, still requiring the presence and action of a physiotherapist, and remain somewhat expensive.

\section{The Limits of Standardization}

Following pain and pathologies linked to the practice of MM for physiotherapist, a second wave of full automated systems has rapidly emerged. Although apparently similar, these tools were distinct by the substitution of the physiotherapist by a qualified operator specific to each machine. Unlike other devices, once turned on, some of these apparatus operate independently and therefore no longer required the intervention of a third person. Unfortunately, a standardized protocol was implemented without providing real adjustments to/by the user. Currently, several commercials devices, such as intermittent sequential pneumatic (Zelikovski et al., 1993), warm underwater water-jet massages (Viitasalo et al., 1995), and whole body vibrations (Edge et al., 2009), are thus available (Poppendieck et al., 2016). Unlike MM, during which the physiotherapist may encounter difficulties in applying constant pressures, techniques and durations, these devices providing whole body vibrations allow a deep control of vibration frequency, duration, and amplitude (Edge et al., 2009). In practice, these devices demonstrated limited effectiveness on physical performance (e.g., running performance, strength) and inconclusive results on recovery and physiological markers such as creatine kinase activity, $\mathrm{pH}$, and lactate after intense effort (Zelikovski et al., 1993; Edge et al., 2009; Lau and Nosaka, 2011). We assume that individualization of the massage, incorporating morphology and expectations of the user, would certainly provide greater benefits. While some devices allow users to adjust few parameters of the massage, such modifications are not yet ergonomic (Golovin et al., 2018). Likewise, adjusting the program remains often impossible once the routine initiated. In all cases, the interaction between the user and the device therefore remains restricted to a retroactive motor control strategy for the user.

\section{The Challenges of Robotics}

Advances in robotics gradually spread within the field of medicine (Petrescu et al., 2016). Like the da Vinci surgical robot and the ROSA ${ }^{\mathrm{TM}}$ spine robot, it is clearly established that robots can assist surgeons with precision during minimally invasive 
procedures such as arthroscopy or laparoscopic splenectomy (Chapman et al., 2002; Lopez et al., 2013; Lefranc and Peltier, 2016). The increasing amount of robotic intervention should be considered within a broader framework. Indeed, once purely human, several medical interventions now seem to involve increasing amounts of robotic solutions. Massage interventions, for instance, could be envisioned as part of a continuum extending from purely robotic to purely human interventions. Nonetheless, robotic solutions remain insufficient and suffer from several limitations, particularly in terms of individualization, that hampers their therapeutic relevance in the absence of medical supervision. Due to the complexities and specificities of clinical interventions, it seems difficult to purely replace the massage delivered by a physiotherapist by a robot. There are multiple degree of adjustments to the patient's characteristics that remain difficult (not to say impossible) to implement in a robot. For these reasons, innovation in terms of robotic massages quickly spread to the field of wellness, less demanding and easier to reproduce. In this context, massage robots can be regarded as an important support, albeit emphasizing that the robot remains a tool, and not a possible avatar that could substitute actual human interventions.

Two similar projects, one Russian in $1998^{1}$, and a second in Israel, developed back massage robots, but failed to move from the project stage to commercial production (Nissim, 2001). In Japan, the Waseda University and Asahi Roentgen company developed the Waseda Asahi Oral-Rehabiliation Robot 1 (WAO1) (Takanishi et al., 2008, 2009). This robotic device, originally designed to promote recovery of temporomandibular disorders, was highly technical, very expensive, and targeted a specific population. Experiments provided useful information on the pressure exerted on masseter and temporal muscles, with values ranging from $100 \mathrm{~g}$ to $1.5 \mathrm{~kg}$ (Koga et al., 2008; Ariji et al., 2009a,b, 2010; Ishii et al., 2009; Obokawa et al., 2009; Solis et al., 2009; Hiraiwa et al., 2013; Table 8). The most effective pressure inducing a better easy-mouth opening was $800 \mathrm{~g}$ on small facial muscles. This robot also increased perceived comfort of users, muscle pain management, increased perceived heat, and promoted functional motor recovery (e.g., mouth opening, blood circulation, saliva production, muscle thickness (Koga et al., 2008; Ariji et al., 2009a,b, 2010, 2015, 2016; Ishii et al., 2009; Obokawa et al., 2009; Solis et al., 2009; Hiraiwa et al., 2013; Table 8). Other similar robotics projects provided promising results with a drop in lumbar strain, heart rate and muscle activity (Peng et al., 2010; Luo and Chang, 2011; Hu et al., 2013; Table 8). Finally, a robotic massage system achieved attractive performance on relaxation by a respective decrease and increase of beta and alpha powers (Luo et al., 2016; Table 8). However, due to the small sample sizes and the complex study design, more experimental investigation remained needed to validate these results. A critical strength of these automated devices is the autonomy and the lack of external intervention of a physiotherapist, but they do still not allow individualizing the massage per se. For instance, the intensity of the massage did not integrate the pain threshold tolerated by the user and the preprogrammed trajectories did not really adapt to the morphology of each person. The available robotic massages

${ }^{1}$ http://medicalrobot.narod.ru/articles.html therefore positioned the user in a passive situation, once again favoring a retroactive control mode, similar to that elicited by the MM. Furthermore, by treating a single relatively restricted area, the robot ended up repeating the same trajectories. In view of these circumstances, the lack of human/robot interaction prevents from real anticipation of the massage maneuvers by the user, hence reducing a switch from a retroactive to a proactive control mode. For these reasons, and given the high cost of these solutions, such devices have not yet reached the market.

\section{The Perspectives of an Interactive and Autonomous Robotics}

In this review, we shall consider a conceptual approach intended as a preamble to an original and timely research topic. Beyond a conceptual comparison, we question the possibility of an emerging solution to really match the two modes of control of the participant receiving the massage. Through incorporation of sensors into each axis, the last generation of devices, called collaborative robots, offer promising and innovative solutions which might definitively resolve the main issues mentioned previously. A Singaporean startup (AiTreat) developed since 2015 a device, called EMMA, specialized in the 'Tui Na' therapeutic massage. Although this massage robot uses some principles of artificial intelligence to customize massage trajectories, it is not entirely autonomous. The machine still requires the intervention of a health professional to identify the treatment areas and set the robot (Qiu et al., 2019). A Spanish company, Adamo Robot, then developed a physiotherapeutic robotic treatment solution since 2015. This device has the particularity of operating with compressed air, therefore without direct contact with the user (Jimenez, 2019). In the same massage robotic field, Massage Robotics, an American startup, developed a concept dedicated to massage centers, but the patent accompanying this project has been abandoned (Mackin, 2017). Indeed, based on a patent already existing in the field, their patent was refused after an analysis by a validation office, due to a lack of innovative character (Nissim, 2001). Finally, Capsix Robotics, a French startup, developed since 2016 a solution with a iYU ${ }^{\circledR}$ robot, intended for full autonomy and back muscle relaxation. The robotic device, equipped with a 3D sensor and coupled to its generic model, is expected to reproduce trajectories on any type of morphology (Eyssautier and Gibert, 2018). These different projects represent emerging solutions to make massages accessible to as many people as possible in the gym or workplace, for example. However, to our knowledge, no study has been carried out to demonstrate the effectiveness of massages provided by such collaborative robot. This issue may be critical in ageing population. Japan is the first concerned with the highest rates of aging (Anderson and Hussey, 2000; Koga et al., 2008), and the country anticipates an increased in needs for medical care (Koga et al., 2008). Robotic solutions are scalable and robotic devices allow non-therapeutic and therapeutic interventions with standardized routines, including automatic adaptation to the morphology of the person through preliminary configuration recordings. Interestingly, the most recent robotic solutions also allow for manual control to adjust the pressure applied by the device in real-time. 
TABLE 8 | Different acute effects of robotic massage.

\begin{tabular}{|c|c|c|c|c|c|c|c|c|c|c|c|}
\hline \multirow{2}{*}{$\begin{array}{l}\text { Author } \\
\text { (year) }\end{array}$} & \multirow{2}{*}{$\begin{array}{l}\text { Study } \\
\text { design }\end{array}$} & \multirow[t]{2}{*}{ Sample } & \multicolumn{5}{|c|}{ Robotic massage intervention } & \multirow[t]{2}{*}{ Control } & \multirow{2}{*}{$\begin{array}{l}\text { Others } \\
\text { experimental } \\
\text { groups }\end{array}$} & \multirow{2}{*}{$\begin{array}{l}\text { Test - outcome } \\
\text { measures }\end{array}$} & \multirow[t]{2}{*}{ Effects } \\
\hline & & & Robot & Targeted area & Techniques & $\begin{array}{l}\text { Treatment } \\
\text { time }\end{array}$ & Intensity & & & & \\
\hline $\begin{array}{l}\text { Koga et al. } \\
\text { (2008) }\end{array}$ & СCT & $\begin{array}{l}\text { Head model } 11 \\
\text { healthy subjects }\end{array}$ & WAO-1 & $\begin{array}{l}\text { Masseter and } \\
\text { temporalis }\end{array}$ & $\begin{array}{l}\text { Effleurage, } \\
\text { petrissage (rotation } \\
\text { and rubbing) }\end{array}$ & $\begin{array}{l}1 \times 1-5 \\
\min / \text { parotid } \\
\text { gland }\end{array}$ & $1-10 N$ & No & $\begin{array}{l}\text { Robotic massage } \\
\text { Manual massage }\end{array}$ & $\begin{array}{l}\text { Level of force } \\
\text { Saxon test } \\
\text { Skin temperature } \\
\text { Size of masseter muscle }\end{array}$ & $\begin{array}{l}\text { Both groups } \\
\text { Same force } \\
\text { production } \\
\uparrow \text { production of } \\
\text { saliva(doctor > } \\
\text { robot) } \\
\uparrow \text { skin temperature } \\
\uparrow \text { size of muscle }\end{array}$ \\
\hline $\begin{array}{l}\text { Obokawa } \\
\text { et al. (2009) }\end{array}$ & CCT & $\begin{array}{l}29 \text { healthy subjects } \\
26 \text { subjects with } \\
\text { TMJ disorders }\end{array}$ & WAO-1 & $\begin{array}{l}\text { Masseter and } \\
\text { temporalis }\end{array}$ & $\begin{array}{l}\text { Effleurage, } \\
\text { petrissage (rotation } \\
\text { and rubbing) }\end{array}$ & $1 \times 10 \mathrm{~min}$ & $1-10 N$ & No & $\begin{array}{l}\text { Robotic massage } \\
1 \sim 2 N \\
6 \sim 8 N \\
10 N \\
6-10 N\end{array}$ & $\begin{array}{l}\text { Comfort VAS-10 } \\
\text { Perceived warmth VAS-10 } \\
\text { Easy-mouth opening } \\
\text { VAS-10 } \\
\text { Perceived lameness } \\
\text { VAS-10 }\end{array}$ & $\begin{array}{l}\text { Four groups } \\
\uparrow \text { comfort } \\
\uparrow \text { perceived warmth } \\
6-10 \mathrm{~N} \text { : } \\
\uparrow \text { easy-mouth } \\
\text { opening } \\
\uparrow \text { lameness muscle }\end{array}$ \\
\hline $\begin{array}{l}\text { Ishii et al. } \\
\text { (2009) }\end{array}$ & ССT & 18 healthy subjects & WAO-1 & $\begin{array}{l}\text { Masseter and } \\
\text { temporalis }\end{array}$ & $\begin{array}{l}\text { Effleurage, } \\
\text { petrissage (rotation } \\
\text { and rubbing) }\end{array}$ & $\begin{array}{l}1 \times 120 \mathrm{~s} / \mathrm{par} \\
\text { gland }\end{array}$ & ottede $5 \mathrm{~N}$ & No & $\begin{array}{l}\text { Robotic massage } \\
\text { Manual massage }\end{array}$ & $\begin{array}{l}\text { Saxon test } \\
\text { Skin temperature } \\
\text { Width of masseter muscle }\end{array}$ & $\begin{array}{l}\text { Both groups } \\
\uparrow \text { production of } \\
\text { saliva } \\
\uparrow \text { fascial skin } \\
\text { temperature } \\
\uparrow \text { width muscle }\end{array}$ \\
\hline $\begin{array}{l}\text { Ariji et al. } \\
\text { (2009a) }\end{array}$ & СCT & $\begin{array}{l}6 \text { healthy subjects } \\
6 \text { subjects with } \\
\text { TMJ } \\
\text { disorders }\end{array}$ & WAO-1 & $\begin{array}{l}\text { Masseter and } \\
\text { temporalis }\end{array}$ & $\begin{array}{l}\text { Effleurage, } \\
\text { petrissage (rotation } \\
\text { and rubbing) }\end{array}$ & $7 \times 60 \mathrm{~s} / \mathrm{mus}$ & cle-12 N & No & $\begin{array}{l}\text { Robotic massage } \\
1 \sim 2 \mathrm{~N} \\
6 \sim 8 \mathrm{~N} \\
10 \mathrm{~N} \\
3 \text { times/2 week } \\
\text { over } \\
6-22 \text { weeks }\end{array}$ & $\begin{array}{l}\text { Pain VAS-10 } \\
\text { Impediments of daily life } \\
\text { VAS-10 } \\
\text { Perceived comfort VAS-10 } \\
\text { Perceived warmth VAS-10 } \\
\text { Easy-mouth opening } \\
\text { VAS-10 }\end{array}$ & $\begin{array}{l}\downarrow \text { muscle pain } \\
\uparrow \text { daily life } \\
6 \sim 8 \mathrm{~N}: \uparrow \text { comfort } \\
6-10 \mathrm{~N}: \uparrow \text { warmth } \\
10 \mathrm{~N} \text { : } \\
\uparrow \text { easy-mouth } \\
\text { opening }\end{array}$ \\
\hline $\begin{array}{l}\text { Ariji et al. } \\
\text { (2009b) }\end{array}$ & СCT & $\begin{array}{l}16 \text { healthy subjects } \\
2 \text { subjects with } \\
\text { TMJ disorders }\end{array}$ & WAO-1 & $\begin{array}{l}\text { Masseter and } \\
\text { temporalis }\end{array}$ & $\begin{array}{l}\text { Effleurage, } \\
\text { petrissage (rotation } \\
\text { and rubbing) }\end{array}$ & $7 \times 60 \mathrm{~s} / \mathrm{mus}$ & cle-12 N & No & $\begin{array}{l}1 \sim 2 \mathrm{~N} \\
6 \sim 8 \mathrm{~N} \\
8-10 \mathrm{~N} \\
10 \mathrm{~N} \\
3 \text { times/2 weeks }\end{array}$ & $\begin{array}{l}\text { Pain VAS-10 } \\
\text { Easy-mouth opening } \\
\text { VAS-10 } \\
\text { Perceived comfort VAS-10 } \\
\text { Masseter stiffness index }\end{array}$ & $\begin{array}{l}\downarrow \text { muscle pain } \\
\uparrow \text { easy mouth } \\
\text { opening } \\
6-10 \mathrm{~N}: \uparrow \text { comfort } \\
6-10 \mathrm{~N}: \uparrow \text { muscle } \\
\text { stiffness index }\end{array}$ \\
\hline
\end{tabular}


TABLE 8 | Continued

\begin{tabular}{|c|c|c|c|c|c|c|c|c|c|c|c|}
\hline \multirow{2}{*}{$\begin{array}{l}\text { Author } \\
\text { (year) }\end{array}$} & \multirow{2}{*}{$\begin{array}{l}\text { Study } \\
\text { design }\end{array}$} & \multirow[t]{2}{*}{ Sample } & \multicolumn{5}{|c|}{ Robotic massage intervention } & \multirow[t]{2}{*}{ Control } & \multirow{2}{*}{$\begin{array}{l}\text { Others } \\
\text { experimental } \\
\text { groups }\end{array}$} & \multirow{2}{*}{$\begin{array}{l}\text { Test - outcome } \\
\text { measures }\end{array}$} & \multirow[t]{2}{*}{ Effects } \\
\hline & & & Robot & Targeted area & Techniques & $\begin{array}{l}\text { Treatment } \\
\text { time }\end{array}$ & Intensity & & & & \\
\hline $\begin{array}{l}\text { Solis et al. } \\
\text { (2009) }\end{array}$ & СCT & 12 healthy subjects & $\begin{array}{l}\text { WAO-1 } \\
\text { WAO-1R }\end{array}$ & $\begin{array}{l}\text { Masseter and } \\
\text { temporalis }\end{array}$ & $\begin{array}{l}\text { Effleurage, } \\
\text { petrissage (rotation } \\
\text { and rubbing) }\end{array}$ & \multicolumn{2}{|c|}{$1 \times 60$ s/muscle-12 N } & No & $\begin{array}{l}\text { Robotic massage } \\
\text { WAO-1 } \\
\text { WAO-1R }\end{array}$ & $\begin{array}{l}\text { Time index } \\
\text { Masseter thickness } \\
\text { Mouth opening index } \\
\text { Skin temperature }\end{array}$ & $\begin{array}{l}\text { WAO-1R }>\text { WAO } \\
\downarrow \text { require time } \\
\uparrow \text { muscle thickness } \\
\text { Trend } \uparrow \text { mouth } \\
\text { opening } \\
\text { NS change skin } \\
\text { temperature }\end{array}$ \\
\hline $\begin{array}{l}\text { Ariji et al. } \\
\text { (2010) }\end{array}$ & CCT & $\begin{array}{l}15 \text { subjects with } \\
\text { single or bilateral } \\
\text { TMJ disorders }\end{array}$ & WAO-1 & $\begin{array}{l}\text { Masseter and } \\
\text { temporal }\end{array}$ & $\begin{array}{l}\text { Effleurage, } \\
\text { petrissage (rotation } \\
\text { and rubbing) }\end{array}$ & $\begin{array}{l}7- \\
10 \times 60 \mathrm{~s} / \mathrm{mu}\end{array}$ & $\begin{array}{l}8-12 \mathrm{~N} \\
\text { scle }\end{array}$ & & $\begin{array}{l}\text { Unilateral robotic } \\
\text { massage } \\
\text { Bilateral robotic } \\
\text { massage } \\
3 \text { times/week over } \\
\text { 6-weeks }\end{array}$ & $\begin{array}{l}\text { Masseter thickness } \\
\text { Intramuscular sonographic } \\
\text { appearence } \\
\text { Pain VAS-10 } \\
\text { Perceived comfort VAS-10 } \\
\text { Perceived warmth VAS-10 } \\
\text { Easy-mouth opening } \\
\text { VAS-10 }\end{array}$ & $\begin{array}{l}\downarrow \text { muscle thickness } \\
\text { for symptomatic } \\
\text { side } \\
\downarrow \text { muscle pain } \\
\downarrow \text { anaeochoic areas } \\
\uparrow \text { comfort } \\
\uparrow \text { warmth } \\
\uparrow \text { easy-mouth } \\
\text { opening }\end{array}$ \\
\hline $\begin{array}{l}\text { Peng et al. } \\
\text { (2010) }\end{array}$ & $\mathrm{RCT}$ & 1 healthy man & $\begin{array}{l}\text { Ronot - not } \\
\text { reported }\end{array}$ & Back muscles & $\begin{array}{l}\text { Pushing, picking-up } \\
\text { and kneading }\end{array}$ & NR & NR & No & Robotic massage & $\begin{array}{l}\text { Heart rate } \\
\text { Breathing rate } \\
\text { Skin temperature }\end{array}$ & $\begin{array}{l}\downarrow \text { heart rate } \\
\text { NS change } \\
\text { breathing rate } \\
\text { NS change skin } \\
\text { temperature }\end{array}$ \\
\hline $\begin{array}{l}\text { Luo and } \\
\text { Chang (2011) }\end{array}$ & $\mathrm{RCT}$ & 5 healthy adults & $\begin{array}{l}\text { Multi-finger robot } \\
\text { hand }\end{array}$ & Shoulder & Grasp-kneading & $1 \times 10 \mathrm{~min}$ & $1-20 N$ & Yes & $\begin{array}{l}\text { Hand massage } \\
\text { Robot hand } \\
\text { massage }\end{array}$ & Muscle activity & $\begin{array}{l}\text { Both groups } \\
\downarrow \text { muscle activity }\end{array}$ \\
\hline $\begin{array}{l}\text { Hiraiwa et al. } \\
\text { (2013) }\end{array}$ & $\mathrm{RCT}$ & $\begin{array}{l}16 \text { patients with } \\
\text { myofascial pain } 24 \\
\text { healthy subjects }\end{array}$ & WAO-1 & $\begin{array}{l}\text { Masseter and } \\
\text { temporal }\end{array}$ & $\begin{array}{l}\text { Effleurage, } \\
\text { petrissage (rubbing } \\
\text { movement) }\end{array}$ & $\begin{array}{l}7- \\
10 \times 60 \mathrm{~s} / \mathrm{mu}\end{array}$ & $\begin{array}{l}6-14 N \\
\text { scle }\end{array}$ & Yes & $\begin{array}{l}\text { Patients } 1 \\
\text { time/week or } 2 \\
\text { weeks over 6-12 } \\
\text { weeks }\end{array}$ & $\begin{array}{l}\text { Masseter PPT } \\
\text { Pain VAS-10 } \\
\text { Impediments of daily life } \\
\text { VAS-10 } \\
\text { Perceived comfort VAS-10 } \\
\text { Perceived warmth VAS-10 } \\
\text { Easy-mouth opening } \\
\text { VAS-10 } \\
\text { every } 3 \text { sessions }\end{array}$ & $\begin{array}{l}\downarrow \text { sensivity only in } \\
\text { patients } \\
\downarrow \text { muscle pain } \\
\uparrow \text { comfort } \\
\uparrow \text { warmth } \\
\uparrow \text { easy-mouth } \\
\text { opening }\end{array}$ \\
\hline
\end{tabular}


TABLE 8 | Continued

\begin{tabular}{|c|c|c|c|c|c|c|c|c|c|c|c|}
\hline \multirow{2}{*}{$\begin{array}{l}\text { Author } \\
\text { (year) }\end{array}$} & \multirow{2}{*}{$\begin{array}{l}\text { Study } \\
\text { design }\end{array}$} & \multirow[t]{2}{*}{ Sample } & \multicolumn{5}{|c|}{ Robotic massage intervention } & \multirow[t]{2}{*}{ Control } & \multirow{2}{*}{$\begin{array}{l}\text { Others } \\
\text { experimental } \\
\text { groups }\end{array}$} & \multirow{2}{*}{$\begin{array}{l}\text { Test - outcome } \\
\text { measures }\end{array}$} & \multirow[t]{2}{*}{ Effects } \\
\hline & & & Robot & Targeted area & Techniques & $\begin{array}{l}\text { Treatment } \\
\text { time }\end{array}$ & Intensity & & & & \\
\hline $\begin{array}{l}\text { Lei Hu et al. } \\
\text { (2013) }\end{array}$ & $\mathrm{RCT}$ & $\begin{array}{l}30 \text { patients with } \\
\text { lumbar muscle } \\
\text { strain }\end{array}$ & $N R$ & $\begin{array}{l}\text { Latissimus } \\
\text { dorsi and } \\
\text { erector spinae }\end{array}$ & $\begin{array}{l}\text { Rolling, thumb } \\
\text { kneading, pinching, } \\
\text { pressing and } \\
\text { vibrating }\end{array}$ & $\begin{array}{l}3^{\star} \text { techniques } \\
\text { with interval } \\
\text { about } 5 \mathrm{~min}\end{array}$ & $N R$ & No & $\begin{array}{l}\text { Robotic massage } \\
\text { (based on the } \\
\text { expert database) }\end{array}$ & $\begin{array}{l}\text { Lumbar PPT } \\
\text { Lumbar strain VAS-10 }\end{array}$ & $\begin{array}{l}\downarrow \text { lumbar sensitivity } \\
\downarrow \text { lumbar strain }\end{array}$ \\
\hline $\begin{array}{l}\text { Ariji et al. } \\
\text { (2015) }\end{array}$ & $\mathrm{RCT}$ & $\begin{array}{l}41 \text { patients with } \\
\text { temporomandibular } \\
\text { disorder }\end{array}$ & WAO-1 & $\begin{array}{l}\text { Masseter and } \\
\text { temporalis }\end{array}$ & $\begin{array}{l}\text { Effleurage, } \\
\text { petrissage (rotation } \\
\text { and rubbing) }\end{array}$ & $7 \times 60 \mathrm{~s} / \mathrm{muscl}$ & $16-14 N$ & No & $\begin{array}{l}\text { Effective group } \\
\text { Ineffective group } \\
5 \text { times/2 weeks } \\
\text { over } 12 \text { weeks }\end{array}$ & $\begin{array}{l}\text { Muscle thickness } \\
\text { Pain VAS-10 } \\
\text { Maximal mouth opening } \\
\text { Impediments of daily life } \\
\text { VAS-10 } \\
\text { Perceived comfort VAS-10 } \\
\text { Perceived warmth VAS-10 } \\
\text { Easy-mouth opening } \\
\text { VAS-10 } \\
\text { all } 3 \text { sessions }\end{array}$ & $\begin{array}{l}\downarrow \text { muscle thickness } \\
\text { symptomatic } \\
\downarrow \text { muscle pain } \\
\uparrow \text { maximal mouth } \\
\text { opening } \\
\uparrow \text { daily life } \\
\uparrow \text { comfort } \\
\uparrow \text { warmth } \\
\uparrow \text { easy-mouth } \\
\text { opening }\end{array}$ \\
\hline $\begin{array}{l}\text { Ariij et al. } \\
\text { (2016) }\end{array}$ & $\mathrm{RCT}$ & $\begin{array}{l}37 \text { patients with } \\
\text { TMJ disorders }\end{array}$ & WAO-1 & $\begin{array}{l}\text { Masseter and } \\
\text { temporalis }\end{array}$ & $\begin{array}{l}\text { Effleurage, } \\
\text { petrissage (rotation } \\
\text { and rubbing) }\end{array}$ & $7 \times 60 \mathrm{~s} / \mathrm{muscl}$ & $\operatorname{leON}$ & No & $\begin{array}{l}\text { Effective group } \\
\text { Ineffective group } 5 \\
\text { times/2 weeks over } \\
\text { a median duration } \\
\text { of } 9.5 \text { weeks }\end{array}$ & $\begin{array}{l}\text { Muscle thickness } \\
\text { Pain VAS-10 } \\
\text { Maximal mouth opening } \\
\text { pre- and post-treatment } \\
\text { TO, } T+1,5 \text { weeks }\end{array}$ & $\begin{array}{l}\uparrow \text { frequency of } \\
\text { visibility of the } \\
\text { distinct } \\
\text { intramuscular echo } \\
\text { genic bands } \downarrow \\
\text { elasticity index ratio } \\
\uparrow \text { maximal mouth } \\
\text { opening }\end{array}$ \\
\hline $\begin{array}{l}\text { Luo et al. } \\
\text { (2016) }\end{array}$ & $\mathrm{RCT}$ & 7 healthy sibjects & $\begin{array}{l}\text { Robot - not } \\
\text { reported }\end{array}$ & Back & $\begin{array}{l}\text { Pressing, rubbing } \\
\text { and stroking }\end{array}$ & $1 \times 10 \mathrm{~min}$ & $N R$ & No & Massage robotic & $\begin{array}{l}\text { Electrical activity of the } \\
\text { brain pre- and post- } \\
\text { treatment }\end{array}$ & $\begin{array}{l}\uparrow \text { delta power } \\
\downarrow \text { alpha power } \\
\text { (suggesting } \\
\text { relaxation) }\end{array}$ \\
\hline
\end{tabular}

RCT, randomized controlled trial; CCT, controlled clinical trial; TMJ, temporomandibular joint; WAO1-R, Waseda Asahi Oral Rehabilitation Robot 1; N, Newton; NR, not reported; $\uparrow$ indicates increase; $\downarrow$, indicates decrease; NS, not significant. 
To our knowledge, iYU ${ }^{\circledR}$ robot is the first device allowing users to implement such options, hence conceptually conciliating the proactive and retroactive modes of action control. From a conceptual viewpoint, such advent in robotic solutions might be a pioneering birth for a new kind of massages combining these two modes of action control. A major innovation of such devices would offer the opportunity to navigate from automated massage routines to user-controlled massage routines. When the robot operates based on a predetermined massage mode selected by the user, a primary retroactive motor control strategy would be engaged as long as the trajectories cannot be predicted by the participant, i.e., such as during a MM. By interacting with the machine and controlling the parameters of the massage with a remote-control device, the user could switch to a proactive mode of action control, such as during FR. This transition faculty, from one mode of control to the other, definitely represents an innovative conceptual approach in terms of human-machine interactions.

\section{Limits and Perspectives}

To date, with the development of collaborative robotic massage, it is possible to see a novel stochastic sensorimotor user experience. These robots are now less expensive and provide multiple advantages for users such as increased precision, availability, privacy and user choices. The addition of a remote user control, as in the case of $\mathrm{iYu}^{\circledR}$ Pro, would complete the device and the whole extent of possible fields. In this context, an opportunity to interact with the device during the session would be offered, reconciling the two motor control strategies. Although these emerging solutions and the idea of conceptual bridge are attractive, extreme caution should be exercised and critical aspects questioning both users' safety and benefits of the massage are awaiting experimental investigation. This freedom of use certainly offers new perspectives, but also implies special attention to the level of autonomy granted, so as not to represent any risk for users. Pressure levels and/or trajectories cannot be randomly administered, and these parameters should be predetermined and supervised by a professional. Also, therapeutic massages require consideration of the histological structure and physiological processes occurring in the body (Lima et al., 2020). This aspect represents a major issue since these limits are different from one person to another, depending on the muscle mass, the habit of self-massage and the presence of dysfunctions requiring medical considerations. For both safety and individualization reasons, purely replacing therapeutic massage interventions classically administered by physiotherapists by a robotic device appears impossible. It is indeed necessary to obtain feedback during the massage routine, directly from the patient and as a result of palpation performed by the therapist. Nonetheless, new types of robotic massages should continue being tested in experimental studies, in particular to differentiate the effects of robotic massages in a so-called preventive/wellness context, from those encountered in a therapeutic context.

In addition, from an ethical standpoint, robotic replicates of MM could easily be considered an inappropriate substitute to actual human interventions. Nonetheless, this should not condemn the potential relevance of robotic solutions. These offer many advantages, particularly from a preventive viewpoint.
Considering the important workload for physiotherapists and frequent limited medical resources, robotic devices represent a solid alternative to provide assistance in their tasks (Golovin et al., 2018). They may alleviate part of the workload faced by medical professionals, and be used to administer simple and reproducible preliminary manipulations. A compound benefit would be allowing physiotherapists to focus on more complex and demanding interventions which cannot be performed by a robot (e.g., joint mobilization, stretching and strengthening exercises). For instance, a collaborative and intelligent robot could be an efficient tool to reduce the risk of musculoskeletal injuries associated with the lack of joint mobilization (e.g., thumb, wrist, shoulder, neck and low back pain). Robotic solutions would also provide an opportunity to democratize access to the practice of massage or self-massage, and thus contribute to improve well-being, health and therapeutic outcomes (Golovin et al., 2018).

Nonetheless, the use of a robotic device for curative massage interventions is questionable. It raises the issue of whether the actual experience of a physiotherapist can be robotized. Physiotherapists adjust their manipulations based on the reaction of their patient. Apart from the massage of scar tissue, MM requires intense and repetitive work by the practitioner. The fine adjustments derived from ongoing feedback, which are continuously available to the physiotherapist, remain essential to the treatment efficacy. MM remains, in this view, a specific form of human interaction that cannot be restricted to mechanical pressures, and robots remain, at this point, a tool at the disposal of medical practitioners.

Eventually, the presence of a remote control allowing to interact in real-time with the robotic device during the massage may hamper the benefits of the massage. For instance, in a clinical context, the patient could avoid the necessary amount of pain associated with pain in edema resorption routines. Also, each control command of the user on the remote requires cognitive operations. Requirements for cognitive control during the massage might preclude optimal states of relaxation. During $\mathrm{MM}$, the user usually manages to detach himself from the effects of the routine by practicing the so-called "letting go" (Corner et al., 1995; Richards, 1998). Among the main unresolved questions, researchers still have to determine whether users are able to relax despite the cognitive mobilization required by the remote control and the interaction with the device. Researchers should also question whether a robotic massage may perceived as being as effective as a MM performed by a physiotherapist for wellness purposes, whether its benefits are similar to those of FR or MM, and whether it may influence psychological (e.g., perceived relaxation, fatigue, pain) and physiological variables (e.g., decrease in perceived anxiety, decreased arousal) in a similar way. Resolving these issues will undoubtedly be an exciting focus of research in the coming years.

\section{AUTHOR CONTRIBUTIONS}

YK, AG and FDR designed the conceptual background of the review and wrote the manuscript. YK, CE, AG, and FDR read, amended, and approved the final version. 


\section{REFERENCES}

Abels, K. M. (2013). The Impact of Foam Rolling on Explosive Strength and Excitability of the Motor Neuron Pool: Materials Science. Austin, TX: The University of Texas at Austin.

Aboodarda, S., Spence, A., and Button, D. C. (2015). Pain pressure threshold of a muscle tender spot increases following local and non-local rolling massage. BMC Musculoskelet. Disord. 16:265. doi: 10.1186/s12891-015-0729-5

Abrantes, R., Nunes, S., Monteiro, E., Fiuza, A., Cesar Cunha, J., Ribeiro, M., et al. (2019). Massage acutely increased muscle strength and power force. J. Exerc. Physiol. Online 22, 100-109.

Albert, W. J., Currie-Jackson, N., and Duncan, C. A. (2008). A survey of musculoskeletal injuries amongst Canadian massage therapists. J. Bodywork Movement Ther. 12, 86-93. doi: 10.1016/j.jbmt.2007.03.003

Anderson, G. F., and Hussey, P. S. (2000). Population aging: a comparison among industrialized countries. Health Aff 19, 191-203. doi: 10.1377/hlthaff.19.3.191

Andrade, C. K. (2013). Outcome-Based Massage: Putting Evidence into Practice. Philadelphia, PA: Lippincott Williams and Wilkins.

Arabaci, R. (2008). Acute effects of pre-event lower limb massage on explosive and high speed motor capacities and flexibility. J. Sports Sci. Med. 7, 549-555.

Arazi, H., Asadi, A., and Hoseini, K. (2012). Comparison of two different warmups (static-stretching and massage): effects on flexibility and explosive power. Acta Kinesiol. 6, 55-59.

Ariji, Y., Katsumata, A., Hiraiwa, Y., Izumi, M., Iida, Y., Goto, M., et al. (2009a). Use of sonographic elastography of the masseter muscles for optimizing massage pressure : a preliminary study. J. Oral Rehabil. 36, 627-635. doi: 10.1111/j.13652842.2009.01977.x

Ariji, Y., Katsumata, A., Hiraiwa, Y., Izumi, M., Sakuma, S., Shimizu, M., et al. (2010). Masseter muscle sonographic features as indices for evaluating efficacy of massage treatment. Oral Radiol. Endodontol. 110, 517-526. doi: 10.1016/j. tripleo.2010.05.003

Ariji, Y., Katsumata, A., Ogi, N., Izumi, M., Sakuma, S., Iida, Y., et al. (2009b). An oral rehabilitation robot for massaging the masseter and temporal muscles : a preliminary report. Oral Radiol. 25, 53-59. doi: 10.1007/s11282-009-0014-0

Ariji, Y., Nakayama, M., Nishiyama, W., Ogi, N., Sakuma, S., Katsumata, A., et al. (2015). Potential clinical application of masseter and temporal muscle massage treatment using an oral rehabilitation robot in temporomandibular disorder patients with myofascial pain. CRANIO $^{\circledR}$ 33, 256-262. doi: 10.1179/ 2151090314Y.0000000030

Ariji, Y., Nakayama, M., Nishiyama, W., Ogi, N., Sakuma, S., Katsumata, A., et al. (2016). Can sonographic features be efficacy predictors of robotic massage treatment for masseter and temporal muscle in patients with temporomandibular disorder with myofascial pain? $C R A N I O^{\circledR} 34,13-19$. doi: 10.1179/2151090314Y.0000000037

Arroyo-Morales, M., Olea, N., Martínez, M. M., Hidalgo-Lozano, A., RuizRodríguez, C., and Díaz-Rodríguez, L. (2008). Psychophysiological effects of massage-myofascial release after exercise : a randomized sham-control study. J. Alternat. Compl. Med. 14, 1223-1229. doi: 10.1089/acm.2008.0253

Baumgart, C., Freiwald, J., Kühnemann, M., Hotfiel, T., Hüttel, M., and Hoppe, M. W. (2019). Foam rolling of the calf and anterior thigh : biomechanical Loads and acute effects on vertical jump height and muscle stiffness. Sports 7:27. doi: $10.3390 /$ sports7010027

Beier, Z., Earp, I., and Korak, J. A. (2019). Self-myofascial release does not improve back squat range of motion, alter muscle activation, or aid in perceived recovery 24-hours following lower body resistance training. Int. J. Exerc. Sci. 12, 839-846.

Best, T. M., Hunter, R., Wilcox, A., and Haq, F. (2008). Effectiveness of sports massage for recovery of skeletal muscle from strenuous exercise. Clin. J. Sport. Med. 18, 446-460. doi: 10.1097/jsm.0b013e31818837al

Boguszewski, D., Falkowska, M., Adamczyk, J. G., and Białoszewski, D. (2017). Influence of foam rolling on the functional limitations of the musculoskeletal system in healthy women. Biomed. Hum. Kinet. 9, 75-81. doi: 10.1515/bhk2017-0012

Bradbury-Squires, D. J., Noftall, J. C., Sullivan, K. M., Behm, D. G., Power, K. E., and Button, D. C. (2014). Roller-massager application to the quadriceps and knee-joint range of motion and neuromuscular efficiency during a lunge. J. Athletic Train. 49, 133-140. doi: 10.4085/1062-6050-49.5.03

Bradley, J., Gomez, J., and Woods, T. (2016). The effect of foam rolling on subsequent exercise performance in man. Sec. Biomed. Sci. 185, S45-S45.
Braver, T. S. (2012). The variable nature of cognitive control: a dual mechanisms framework. Trends Cogn. Sci. 16, 106-113. doi: 10.1016/j.tics.2011.12.010

Brengesjö, O., and Lohaller, J. (2017). Effects of foam rolling on ankle joint ROM and hamstring flexibility. Open Orthop. J. 9, 450-455.

Brummitt, J. (2008). The role of massage in sports performance and rehabilitation : current evidence and future direction. North Am. J. Sports Phys. Ther. 3, 7-21.

Burk, C., Perry, J., Lis, S., Dischiavi, S., and Bleakley, C. (2019). Can myofascial interventions have a remote effect on ROM? a systematic review and metaanalysis. J. Sport Rehabil. 1, 1-23. doi: 10.1123/jsr.2019-0074

Calvert, R. N. (2002). The History of Massage : An Illustrated Survey From Around the World. Rochester: Inner Traditions-Bear and Co.

Capobianco, R. A., Mazzo, M. M., and Enoka, R. M. (2019). Self-massage prior to stretching improves flexibility in young and middle-aged adults. J. Sports Sci. 37, 1543-1550. doi: 10.1080/02640414.2019.1576253

Carcano, Y., Isembrand, B., Wieczorek, G., and Boudjemaa, B. (2010). Le ressenti de sportifs lors d'un massage de récupération en termes de douleur et fatigue musculaires et de bien-être. Rôle Place Bandages Adhésifs Actifs Coule. 10, 46-50. doi: 10.1016/S1779-0123(10)74907-X

Casanova, N., Reis, J. F., Vaz, J. R., Machado, R., Mendes, B., Button, D. C., et al. (2017). Effects of roller massager on muscle recovery after exercise-induced muscle damage. J. Sports Sci 36, 56-63. doi: 10.1080/02640414.2017.1280609

Cavanaugh, T. (2016). The Effects of Foam Rolling on Muscular Co-activation Around the Knee Joint. Master of Science in Kinesiology. St. John's, NL: Memorial University of Newfoundland.

Ceca, D., Elvira, L., Guzmán, J. F., and Pablos, A. (2017). Benefits of a selfmyofascial release programme on health-related quality of life in people with fibromyalgia : a randomized controlled trial. J. Sports Med. Phys. Fitness 57, 993-1002.

Cervin, A., Eker, J., Bernhardsson, B., and Årzén, K.-E. (2002). Feedbackfeedforward Scheduling of control tasks. Real Time Syst. 23, 25-53. doi: 10.1023/ A: 1015394302429

Chan, Y.-C., Wang, T.-J., Chang, C.-C., Chen, L.-C., Chu, H.-Y., Lin, S.-P., et al. (2015). Short-term effects of self-massage combined with home exercise on pain, daily activity, and autonomic function in patients with myofascial pain dysfunction syndrome. J. Phys. Ther. Sci. 27, 217-221. doi: 10.1589/jpts.27.217

Chapman, W. H. H., Albrecht, R. J., Kim, V. B., Young, J. A., and Chitwood, W. R. (2002). Computer-assisted laparoscopic splenectomy with the da VinciTM surgical robot. J. Laparoend. Adv. Surg. Tech. 12, 155-159. doi: 10.1089/ 10926420260188038

Cheatham, S. W., and Baker, R. (2017). Differences in pressure pain threshold among men and women after foam rolling. J. Bodywork Mov. Ther. 21, 978-982. doi: 10.1016/j.jbmt.2017.06.006

Cheatham, S. W., and Kolber, M. J. (2018). Does roller massage with a foam roll change pressure pain threshold of the ipsilateral lower extremity antagonist and contralateral muscle groups? An exploratory study. J. Sport Rehabil. 27, 165-169. doi: 10.1123/jsr.2016-0196

Cheatham, S. W., Kolber, M. J., and Cain, M. (2017). Comparison of video-guided, live instructed, and self-guided foam roll interventions on knee joint range of motion and pressure pain threshold: a randomized controlled trial. Int. J. Sports Phys. Ther. 12, 242-249.

Cheatham, S. W., Kolber, M. J., Cain, M., and Lee, M. (2015). The effects of selfmyofascial release using a foam roll or roller massager on joint range of motion, muscle recovery, and performance: a systematic review. Int. J. Sports Phys. Ther. 10, 827-838.

Cheatham, S. W., and Stull, K. R. (2018a). Comparison of three different density type foam rollers on knee range of motion and pressure pain threshold: a randomized controlled trial. Int. J. Sports Phys. Ther. 13, 474-482.

Cheatham, S. W., and Stull, K. R. (2018b). Comparison of a foam rolling session with active joint motion and without joint motion: a randomized controlled trial. J. Bodywork Movement Ther. 22, 707-712. doi: 10.1016/j.jbmt.2018.01.011

Cheatham, S. W., Stull, K. R., and Kolber, M. J. (2019). Comparison of a vibration roller and a nonvibration roller intervention on knee range of motion and Pressure pain threshold: a randomized controlled trial. J. Sport Rehabil. [Epub ahead of print]. doi: 10.1123/jsr.2017-0164

Cho, S.-H., Kim, S.-H., and Park, D.-J. (2015). The comparison of the immediate effects of application of the suboccipital muscle inhibition and self-myofascial release techniques in the suboccipital region on short hamstring. J. Phys. Ther. Sci. 27, 195-197. doi: 10.1589/jpts.27.195 
Choi, J.-H. (2019). Effect of an exercise program using a foam roller on shoulder height and muscle activity in adults in their twenties with round shoulder. Indian J. Public Health Res. Dev. 10, 1112-1118. doi: 10.5958/0976-5506.2019. 01220.8

Corner, J., Cawley, N., and Hildebrand, S. (1995). An evaluation of the use of massage and essential oils on the wellbeing of cancer patients. Int. J. Palliat. Nurs. 1, 67-73. doi: 10.12968/ijpn.1995.1.2.67

Correira, P. P. (2016). Effects of roller massager on muscle performance, morphology, and oxygenation after exercise-induced muscle damage. J. Sports Sci 36, 56-63.

Crane, J. D., Ogborn, D. I., Cupido, C., Melov, S., Hubbard, A., Bourgeois, J. M., et al. (2012). Massage therapy attenuates inflammatory signaling after exerciseinduced muscle damage. Sci. Transl. Med. 4:119ra13. doi: 10.1126/scitranslmed. 3002882

Cupido, C. (2010). Effects of Massage Therapy After Exhaustive Endurance Exercise in Young Healthy Males. Masters of Science in Kinesiology Thesis. Degree of Masters of Science in Kinesiology, McMaster University, Hamilton, ON.

D'Amico, A., and Paolone, V. (2017). The effect of foam rolling on recovery between two eight hundred metre runs. J. Hum. Kinet. 57, 97-105. doi: 10.1515/ hukin-2017-0051

D’Andrea, J. (2016). Foam Rolling as a Novel Warm-up Technique for Anaerobic Power activities. Wayne, NJ: The William Paterson University of New Jersey.

Dawson, L. G., Dawson, K. A., and Tiidus, P. M. (2004). Evaluating the influence of massage on leg strength, swelling, and pain following a half-marathon. J. Sports Sci. Med. 3:37.

Dębski, P., Białas, E., and Gnat, R. (2019). The parameters of foam rolling, selfmyofascial release treatment: a review of the literature. Biomed. Hum. Kinet. 11, 36-46. doi: 10.2478/bhk-2019-0005

Delextrat, A., Calleja-González, J., Hippocrate, A., and Clarke, N. D. (2013). Effects of sports massage and intermittent cold-water immersion on recovery from matches by basketball players. J. Sports Sci. 31, 11-19. doi: 10.1080/02640414. 2012.719241

Do, K., Kim, J., and Yim, J. (2018). Acute effect of self-myofascial release using a foam roller on the plantar fascia on hamstring and lumbar spine superficial back line flexibility. Phys. Ther. Rehabil. Sci. 7, 35-40. doi: 10.14474/ptrs.2018.7.1.35

Drinkwater, E. J., Latella, C., Wilsmore, C., Bird, S. P., and Skein, M. (2019). Foam rolling as a recovery tool following eccentric exercise: potential mechanisms underpinning changes in jump performance. Front. Physiol. 10:768. doi: 10. 3389/fphys.2019.00768

Drust, B., Atkinson, G., Gregson, W., French, D., and Binningsley, D. (2003). The effects of massage on intra muscular temperature in the vastus lateralis in humans. Int. J. Sports Med. 24, 395-399. doi: 10.1055/s-2003-41182

Dupuy, O., Douzi, W., Theurot, D., Bosquet, L., and Dugué, B. (2018). An evidence-based approach for choosing post-exercise recovery techniques to reduce markers of muscle damage, soreness, fatigue, and inflammation: a systematic review with meta-analysis. Front. Physiol. 9:403. doi: 10.3389/fphys. 2018.00403

Edge, J., Mündel, T., Weir, K., and Cochrane, D. J. (2009). The effects of acute whole body vibration as a recovery modality following high-intensity interval training in well-trained, middle-aged runners. Eur. J. Appl. Physiol 105, 421-428. doi: 10.1007/s00421-008-0919-z

Eriksson Crommert, M., Lacourpaille, L., Heales, L. J., Tucker, K., and Hug, F. (2015). Massage induces an immediate, albeit short-term, reduction in muscle stiffness. Scand. J. Med. Sci. Sports 25, e490-e496. doi: 10.1111/sms.12341

Espí-López, G. V., Serra-Añó, P., Cuenca-Martínez, F., Suso-Martí, L., and Inglés, M. (2020). Comparison between classic and light touch massage on psychological and physical functional variables in athletes: a randomized pilot trial. Int. J. Ther. Massage Bodywork 13, 30-37. doi: 10.3822/ijtmb.v13i3.551

Eyssautier, F., and Gibert, G. (2018). Device for Managing the Movements of a Robot, and Associated Treatment Robot. U.S. Patent No Patent No FR3067957. Washington, DC: U.S. Patent and Trademark Office.

Fairall, R. R., Cabell, L., Boergers, R. J., and Battaglia, F. (2017). Acute effects of selfmyofascial release and stretching in overhead athletes with GIRD. J. Bodywork Mov Ther. 21, 648-652. doi: 10.1016/j.jbmt.2017.04.001

Fama, B. J., and Bueti, D. R. (2011). The Acute Effect of Self-Myofascial Release on Lower Extremity Plyometric Performance. Limoges: IRFSS.

Farr, T., Nottle, C., Nosaka, K., and Sacco, P. (2002). The effects of therapeutic massage on delayed onset muscle soreness and muscle function following downhill walking. J. Sci. Med. Sport 5, 297-306. doi: 10.1016/S1440-2440(02) 80018-4

Field, T., Grizzle, N., Scafidi, F., Abrams, S., Richardson, S., Kuhn, C., et al. (1996). Massage theraphy for infants of depressed mothers. Infant Behav. Dev. 19, 107-112. doi: 10.1016/S0163-6383(96)90048-X

Field, T., Hernande-Reif, M., Diego, M., Schanberg, S., and Kuhn, C. (2005). Cortisol decreases and serotonin and dopamine increase following massage therapy. Int. J. Neurosci. 115, 1397-1413. doi: 10.1080/0020745059095 6459

Fleckenstein, J., Wilke, J., Vogt, L., and Banzer, W. (2017). Preventive and regenerative foam rolling are equally effective in reducing fatigue-related impairments of muscle function following exercise. J. Sports Sci. Med. 16, 474-479.

Garcia-Gutiérrez, M., Guillén-Rogel, P., Cochrane, D., and Marin, P. (2018). Cross transfer acute effects of foam rolling with vibration on ankle dorsiflexion range of motion. J. Musculoskeletal Neuronal Interact. 18, 262-267.

Gaullier, J. (2015). Effets du massage sportif sur la performance et la récupération entre croyances et preuves scientifiques. Limeges: Institut Régional de Formation Sanitaire et Sociale du Limousin.

Ginszt, M., Gawda, P., Smołka, J., Skublewska-Paszkowska, M., Łukasik, E., and Paæko, M. (2017). The immediat effect of self-myofascial release using a foam roller on electromyographic muscle activity. Pol. J. Sports Med. 33, 209-213.

Golovin, V., Samorukov, A., Arkhipov, M., and Kocherevskaya, L. (2018). Robotic restorative massage to increase working capacity. Altern. Integr. Med. 7:2. doi: 10.4172/2327-5162.1000261

Grabow, L., Young, J. D., Byrne, J. M., Granacher, U., and Behm, D. G. (2017). Unilateral rolling of the foot did not affect non-local range of motion or balance. J. Sports Sci. Med. 16, 209-218.

Grieve, R., Barnett, S., Coghill, N., and Cramp, F. (2013). Myofascial trigger point therapy for triceps surae dysfunction: a case series. Man. Ther. 18, 519-525. doi: 10.1016/j.math.2013.04.004

Grieve, R., Goodwin, F., Alfaki, M., Bourton, A.-J., Jeffries, C., and Scott, H. (2015). The immediate effect of bilateral self myofascial release on the plantar surface of the feet on hamstring and lumbar spine flexibility: a pilot randomised controlled trial. J. Bodywork Mov. Ther. 19, 544-552. doi: 10.1016/j.jbmt.2014. 12.004

Guillot, A., Kerautret, Y., Queyrel, F., Schobb, W., and Di Rienzo, F. (2019). Foam rolling and joint distraction with elastic band training performed for 5-7 weeks respectively improve lower limb flexibility. J. Sports Sci. Med. 18, $160-171$.

Guimberteau, J. C. (2004). Promenades sous la peau. Amsterdam: Elsevier Masson. Guimberteau, J. C., Findley, T. W., Kapandji, A. I., and Armstrong, C. (2016). Larchitecture du corps humain vivant: Le monde extracellulaire, les cellules et le fascia révélés par l'endoscopie intratissulaire. Available online at: https://books. google.fr/books?id=19n4DAEACAAJ

Halperin, I., Aboodarda, S. J., Button, D. C., Andersen, L. L., and Behm, D. G. (2014). Roller massager improves range of motion of plantar flexor muscles without subsquent decreases in force parameters. Int. J. Sports Phys. Ther. 9, 92-102.

Han, S., Lee, Y., and Lee, D. (2017). The influence of the vibration form roller exercise on the pains in the muscles around the hip joint and the joint performance. J. Phys. Ther. Sci. 29, 1844-1847. doi: 10.1589/jpts.29.1844

Hasegawa, Y., Ootsuka, T., Fukuda, T., Arai, F., and Kawaguchi, M. (2001). “A relaxation system adapting to user's condition-identification of relationship between massage intensity and heart rate variability," in Proceedings of the IEEE International Conference on Robotics and Automation, Brisbane, 3195-3200. doi: 10.1109/ROBOT.2001.933110

Healey, K. C., Hatfield, D. L., Blanpied, P., Dorfman, L. R., and Riebe, D. (2014). The effects of myofascial release with foam rolling on performance. J. Strength Condition. Res. 28, 61-68. doi: 10.1519/jsc.0b013e3182956569

Hemmings, B., Smith, M., Graydon, J., and Dyson, R. (2000). Effects of massage on physiological restoration, perceived recovery, and repeated sports performance. Br. J. Sports Med. 34:109. doi: 10.1136/bjsm.34.2.109

Hendricks, S., Hill, H., Hollander, S. D., Lombard, W., and Parker, R. (2019). Effects of foam rolling on performance and recovery: a systematic review of the literature to guide practitioners on the use of foam rolling. J. Bodywork Mov. Ther. 24, 151-174. doi: 10.1016/j.jbmt.2019.10.019 
Hilbert, J. E., Sforzo, G. A., and Swensen, T. (2003). The effects of massage on delayed onset muscle soreness. Br. J. Sports Med. 37:72. doi: 10.1136/bjsm.37. 1.72

Hinds, T., McEwan, I., Perkes, J., Dawson, E., Ball, D., and George, K. (2004). Effects of massage on limb and skin blood flow after quadriceps exercise. Med. Sci. Sports Exerc. 36, 1308-1313. doi: 10.1249/01.mss.0000135789.47716.db

Hiraiwa, Y., Ariji, Y., Kise, Y., Sakuma, S., Kurita, K., and Ariji, E. (2013). Efficacy of massage treatment technique in masseter muscle hardness: robotic experimental approach. $C R A N I O{ }^{\circledR} 31,291-299$. doi: 10.1179/crn.2013.31.4.007

Hodgson, D. D., Lima, C. D., Low, J. L., and Behm, D. G. (2018). Four weeks of roller massage training did not impact range of motion, pain pressure threshold, voluntary contractile properties or jump performance. Int. J. Sports Phys. Ther. 13, 835-845. doi: 10.26603/ijspt20180835

Hodgson, D. D., Quigley, P. J., Whitten, J. H. D., Reid, J. C., and Behm, D. G. (2019). Impact of 10-minute interval roller massage on performance and active range of motion. J. Strength Condition. Res. 33, 1512-1523. doi: 10.1519/JSC. 0000000000002271

Hotfiel, T., Swoboda, B., Krinner, S., Grim, C., Engelhardt, M., Uder, M., et al. (2017). Acute effects of lateral thigh foam rolling on arterial tissue perfusion determined by spectral doppler and power doppler ultrasound. J. Strength Cond. Res. 31, 893-900. doi: 10.1519/jsc.0000000000001641

Hu, L., Wang, Y., Zhang, J., Zhang, J., Cui, Y., Ma, L., et al. (2013). A massage robot based on chinese massage therapy. Industr. Robot Int. J. 40, 158-172. doi: 10.1108/01439911311297775

Hughes, G. A., and Ramer, L. M. (2019). Duration of myofascial rolling for optimal recovery, range of motion, and performance: a systematic review of the litterature. Int. J. Sports Phys. Ther. 14, 845-859. doi: 10.26603/ijspt20190845

Ishii, H., Koga, H., Obokawa, Y., Solis, J., Takanishi, A., and Katsumata, A. (2009). Development and experimental evaluation of oral rehabilitation robot that provides maxillofacial massage to patients with oral disorders. Int. J. Robot. Res. 28, 1228-1239. doi: 10.1177/0278364909104295

Iwamoto, K., Mizukami, M., Asakawa, Y., Yoshio, M., Ogaki, R., and Takemura, M. (2016). Effects of friction massage of the popliteal fossa on dynamic changes in muscle oxygenation and ankle flexibility. J. Phys. Ther. Sci. 28, 2713-2716. doi: $10.1589 /$ jpts.28.2713

Jafarnezhadgero, A. A., Majlesi, M., Etemadi, H., and Robertson, D. G. E. (2018). Rehabilitation improves walking kinematics in children with a knee varus: randomized controlled trial. Ann. Phys. Rehabil. Med. 61, 125-134. doi: 10.1016/ j.rehab.2018.01.007

Jakeman, J. R., Byrne, C., and Eston, R. G. (2010). Efficacy of lower limb compression and combined treatment of manual massage and lower limb compression on symptoms of exercise-induced muscle damage in women. J. Strength Condition. Res. 24, 3157-3165. doi: 10.1519/jsc.0b013e3181e4f80c

Jay, K., Sundstrup, E., Søndergaard, S. D., Behm, D., Brandt, M., Særvoll, C. A., et al. (2014). Specific and cross over effects of massage for muscle soreness: Randomized controlled trial. Int. J. Sports Phys. Ther. 9, 82-91.

Jeong, Y., Park, J., Yu, J., Lee, S., Ha, J., Choo, Y., et al. (2019). Immediate effects of release ball massage and self-stretching exercise on hamstring's temperature, range of motion and strength in 20's women. J. Int. Acad. Phys. Ther. Res. 10, 1739-1745. doi: 10.20540/JIAPTR.2019.10.1.1739

Jimenez, G. F. C. (2019). Sistema robótico para tratamientos fisioterapéuticos, mediante robot manipulador colaborativo y aire comprimido. U.S. Patent No ES1222864Y. Washington, DC: U.S. Patent and Trademark Office.

Joshi, D. G., Balthillaya, G., and Prabhu, A. (2018). Effect of remote myofascial release on hamstring flexibility in asymptomatic individuals - a randomized clinical trial. J. Bodywork Mov. Ther. 22, 832-837. doi: 10.1016/j.jbmt.2018.01. 008

Jourdain, C. (2015). "Étude des effets d'une séance de massage hebdomadaire sur la perception des douleurs musculaires et des perceptions de la récupération globale chez des jeunes athlètes de haut niveau," in Proceedings of the Direction Régionale de la Jeuensse, des Sports et de la Cohésion sociale, Paris.

Jung, J., Choi, W., Lee, Y., Kim, J., Kim, H., Lee, K., et al. (2017). Immediate effect of self-myofascial release on hamstring flexibility. Phys. Ther. Rehabil. Sci. 6, 45-51. doi: 10.14474 ptrs.2017.6.1.45

Kaada, B., and Torsteinb, O. (1989). Increase of plasma $\beta$-endorphins in connective tissue massage. Gen. Pharmacol.Vascu. Syst. 20, 487-489. doi: 10.1016/03063623(89)90200-0
Kalén, A., Pérez-Ferreirós, A., Barcala-Furelos, R., Fernández-Méndez, M., Padrón-Cabo, A., Prieto, J. A., et al. (2017). How can lifeguards recover better? A cross-over study comparing resting, running, and foam rolling. Am. J. Emerg. Med. 35:5. doi: 10.1016/j.ajem.2017.06.028

Kalichman, L., and Ben David, C. (2017). Effect of self-myofascial release on myofascial pain, muscle flexibility, and strength: a narrative review. J. Bodywork Mov. Ther. 21, 446-451. doi: 10.1016/j.jbmt.2016.11.006

Kargarfard, M., Lam, E. T. C., Shariat, A., Shaw, I., Shaw, B. S., and Tamrin, S. B. M. (2016). Efficacy of massage on muscle soreness, perceived recovery, physiological restoration and physical performance in male bodybuilders. J. Sports Sci. 34, 959-965. doi: 10.1080/02640414.2015.1081264

Kelly, S., and Beardsley, C. (2016). Specific and cross-over effects of foam rolling on ankle dorsiflexion range of motion. Int. J. Sports Phys. Ther. 11, 544-551.

Kett, A. R., and Sichting, F. (2020). Sedentary behaviour at work increases muscle stiffness of the back: why roller massage has potential as an active break intervention. Appl. Ergon. 82:102947. doi: 10.1016/j.apergo.2019.102947

Killen, B. S., Zelizney, K. L., and Ye, X. (2018). Crossover effects of unilateral static stretching and foam rolling on contralateral hamstring flexibility and strength. J. Sport Rehabil. 28, 1-27. doi: 10.1123/jsr.2017-0356

Kim, K., Park, S., Goo, B.-O., and Choi, S.-C. (2014). Effect of self-myofascial release on reduction of physical stress: a pilot study. J. Phys. Ther. Sci. 26, 1779-1781. doi: 10.1589/jpts.26.1779

Kim, Y., Hong, Y., and Park, H.-S. (2019). A soft massage tool is advantageous for compressing deep soft tissue with low muscle tension: therapeutic evidence for self-myofascial release. Complement. Ther. Med 43, 312-318. doi: 10.1016/j. ctim.2019.01.001

Koga, H., Usuda, Y., Matsuno, M., Ogura, Y., Ishii, H., Solis, J., et al. (2008). "Development of the oral rehabilitation robot WAO-1," in Proceedings of the 2008 2nd IEEE RAS \& EMBS International Conference on Biomedical Robotics and Biomechatronics, Scottsdale, AZ, 556-561.

Kong, P. W., Chua, Y. H., Kawabata, M., Burns, S. F., and Cai, C. (2018). Effect of post-exercise massage on passive muscle stiffness measured using myotonometry-A double-blind study. J. Sports Sci. Med. 17, 599-606.

Kyranoudis, A., Arsenis, S., Ispyrlidis, I., Chatzinikolaou, A., Gourgoulis, V., Kyranoudis, E., et al. (2019). The acute effects of combined foam rolling and static stretching program on hip flexion and jumping ability in soccer players. J. Phys. Educ. Sport 19, 1164-1172. doi: 10.7752/jpes.2019.02169

Lastova, K., Nordvall, M., Walters-Edwards, M., Allnutt, A., and Wong, A. (2018). Cardiac autonomic and blood pressure responses to an acute foam rolling session. J. Strength Condition. Res. 32, 2825-2830. doi: 10.1519/jsc. 0000000000002562

Lau, W. Y., and Nosaka, K. (2011). Effect of vibration treatment on symptoms associated with eccentric exercise-induced muscle damage. Am. J. Phys. Med. Rehabil. 90, 648-657. doi: 10.1097/phm.0b013e3182063ac8

Le Gal, J., Begon, M., Gillet, B., and Rogowski, I. (2018). Effects of self-myofascial release on shoulder function and perception in adolescent tennis players. J. Sport Rehabil. 27, 1-6. doi: 10.1123/jsr.2016-0240

Lee, C.-H., Lai, C.-L., Sung, Y.-H., Lai, M. Y., Lin, C.-Y., and Lin, L.-Y. (2017). Comparing effects between music intervention and aromatherapy on anxiety of patients undergoing mechanical ventilation in the intensive care unit: a randomized controlled trial. Qual. Life Res. 26, 1819-1829. doi: 10.1007/s11136017-1525-5

Lee, H.-I., and Lim, B.-O. (2018). Effects of self myofascial release, elastic band, and stretching exercises on lower extremity alignment and gait in female genu varum. Korean J. Sport Biomech. 28, 207-211. doi: 10.5103/KJSB.2018.28.4.207

Lefranc, M., and Peltier, J. (2016). Evaluation of the ROSATM Spine robot for minimally invasive surgical procedures. Exp. Rev. Med. Dev. 13, 899-906. doi: $10.1080 / 17434440.2016 .1236680$

Leivadi, S., Hernandez-Reif, M., Field, T., O’Rourke, M., D’Arienzo, S., Lewis, D., et al. (1999). Massage therapy and relaxation effects on university dance students. J. Dance Med. Sci. 3, 108-112.

Lim, J.-H., and Park, C.-B. (2019). The immediate effects of foam roller with vibration on hamstring flexibility and jump performance in healthy adults. J. Exerc. Rehabil. 15, 50-54. doi: 10.12965/jer.1836560.280

Lima, C. R., Martins, D. F., and Reed, W. R. (2020). Physiological responses induced by manual therapy in animal models: a scoping review. Front. Neurosci. 14:430. doi: 10.3389/fnins.2020.00430 
Lopez, E., Kwok, K., Payne, C. J., Giataganas, P., and Yang, G. (2013). “Implicit Active Constraints for robot-assisted arthroscopy," in Proceedings of the 2013 IEEE International Conference on Robotics and Automation, Karlsruhe, 53905395. doi: 10.1109/ICRA.2013.6631350

Luo, R. C., and Chang, C. C. (2011). "Electromyographic evaluation of therapeutic massage effect using multi-finger robot hand," in Proceedings of the 2011 IEEE International Conference on Robotics and Automation, Shanghai, 2431-2436. doi: 10.1109/ICRA.2011.5980147

Luo, R. C., Hsu, C.-W., and Chen, S.-Y. (2016). "Electroencephalogram signal analysis as basis for effective evaluation of robotic therapeutic massage," in Proceedings of the 2016 IEEE/RSJ International Conference on Intelligent Robots and Systems (IROS), Daejeon, 2940-2945. doi: 10.1109/IROS.2016.7759455

MacDonald, G. Z., Button, D. C., Drinkwater, E. J., and Behm, D. G. (2014). Foam rolling as a recovery tool after an intense bout of physical activity. Med. Sci. Sports Exerc. 46, 131-142. doi: 10.1249/mss.0b013e3182a123db

MacDonald, G. Z., Penney, M. D. H., Mullaley, M. E., Cuconato, A. L., Drake, C. D. J., Behm, D. G., et al. (2013). An acute bout of self-myofascial release increases range of motion without a subsequent decrease in muscle activation or force. J. Strength Condition. Res. 27, 812-821. doi: 10.1519/jsc. 0b013e31825c2bc1

Macgregor, L. J., Fairweather, M. M., Bennett, R. M., and Hunter, A. M. (2018). The effect of foam rolling for three consecutive days on muscular efficiency and range of motion. Sports Med. Open 4:26. doi: 10.1186/s40798-018-0141-4

Mackin, C. (2017). Robotic Massage Machine and Method of Use. U.S. Patent No US2017266077. Washington, DC: U.S. Patent and Trademark Office.

Madoni, S. N., Costa, P. B., Coburn, J. W., and Galpin, A. J. (2018). Effects of foam rolling on range of motion, peak torque, muscle activation, and the hamstringsto-quadriceps strength ratios. J. Strength Condition. Res. 32, 1821-1830. doi: $10.1519 /$ jsc.0000000000002468

Mancinelli, C. A., Davis, D. S., Aboulhosn, L., Brady, M., Eisenhofer, J., and Foutty, S. (2006). The effects of massage on delayed onset muscle soreness and physical performance in female collegiate athletes. Phys. Ther. Sport 7, 5-13. doi: $10.1016 /$ j.ptsp.2005.10.004

Martínez-Cabrera, F. I., and Núñez-Sánchez, F. J. (2016). Acute effect of a foam roller on the mechanical properties of the rectus femoris based on tensiomyography in soccer players. Int. J. Hum. Mov. Sports Sci. 4, 26-32. doi: 10.13189/saj.2016.040203

Mazzei, B. G. (2019). Different effects of static and vibrating foam rollers on ankle plantar flexion flexibility and neuromuscular activation. Thesis in Exercise Science. Statesboro: Georgia Southern University.

McKechnie, G. J., Young, W. B., and Behm, D. G. (2007). Acute effects of two massage techniques on ankle Joint flexibility and power of the plantar flexors. J. Sports Sci. Med. 6, 498-504.

Mezencevová, V., Torok, J., Czánová, T., and Zajac, J. (2017). Endermologie new aproach in the medicine treatment. Technol. Eng. 14, doi: 10.1515/teen-20170008

Mikesky, A. E., Bahamonde, R. E., Stanton, K., Alvey, T., and Fitton, T. (2002). Acute effects of the stick on strength, power, and flexibility. J. Strength Condition. Res. 16, 446-450. doi: 10.1519/00124278-200208000-00017

Miller, J. K., and Rockey, A. M. (2006). Foam rollers show no increase in the flexibility of the hamstring muscle group. J. Undergraduate Res. 9, 9-14.

Mohr, A. R., Long, B. C., and Goad, C. L. (2014). Effect of foam rolling and static stretching on passive hip-flexion range of motion. J. Sport Rehabil. 23, 296-299. doi: 10.1123/JSR.2013-0025

Monteiro, E. R., Cavanaugh, M. T., Frost, D. M., and Novaes, J. D. S. (2017). Is selfmassage an effective joint range-of-motion strategy? A pilot study. J. Bodywork Mov. Ther. 21, 223-226. doi: 10.1016/j.jbmt.2016.10.003

Monteiro, E. R., da Silva Novaes, J., Cavanaugh, M. T., Hoogenboom, B. J., Steele, J., Vingren, J. L., et al. (2019). Quadriceps foam rolling and rolling massage increases hip flexion and extension passive range-of-motion. J. Bodywork Mov. Ther. 23, 575-580. doi: 10.1016/j.jbmt.2019.01.008

Monteiro, E. R., Škarabot, J., Vigotsky, A. D., Brown, A. F., Gomes, T. M., and Novaes, J. D. S. (2017a). Acute effect of different self-massage volumes on the FMSTM overhead deep squat performance. Int. J. Sports Phys. Ther. 12, 94-104.

Monteiro, E. R., Škarabot, J., Vigotsky, A. D., Brown, A. F., Gomes, T. M., and Novaes, J. D. S. (2017b). Maximum repetition performance after different antagonist foam rolling volumes in the inter-set rest period. Int. J. Sports Phys. Ther. 12, 76-84.
Moraska, A. (2007). Therapist education impacts the massage effect on postrace muscle recovery. Med. Sci. Sports Exerc. 39, 34-37. doi: 10.1249/01.mss. 0000240320.16029.d2

Mori, H., Ohsawa, H., Tanaka, T. H., Taniwaki, E., Leisman, G., and Nishijo, K. (2004). Effect of massage on blood flow and muscle fatigue following isometric lumbar exercise. Med. Sci. Monit. 10, 173-178.

Murali, S., Shanmugam, S. V., Prasaad, G. A., Kumar, M. S., Manoharan, C., Devadasan, S. R., et al. (2014). Fatigue mitigation through the optimization of ergonomic positional parameters in massage therapy using virtual instrumentation. Int. J. Adv. Manufact. Technol. 70, 173-184. doi: 10.1007/ s00170-013-5259-4

Murray, A. M., Jones, T. W., Horobeanu, C., Turner, A. P., and Sproule, J. (2016). Sixty seconds of foam rolling does not affect functional flexibility or change muscle temperature in adolescent athletes. Int. J. Sports Phys. Ther. 11, 765-776.

Myers, T. W. (2013). Anatomy Trains E-Book: Myofascial Meridians for Manual and Movement Therapists. Amsterdam: Elsevier Health Sciences.

Naderi, A., Rezvani, M. H., and Degens, H. (2019). Foam rolling and muscle and joint proprioception after exercise-induced muscle damage. J. Athletic Train. 55, 58-64. doi: 10.4085/1062-6050-459-18

Nakano, H., Kodama, T., Ueda, T., Mori, I., Tani, T., and Murata, S. (2019). Effect of hand and foot massage therapy on psychological factors and EEG activity in elderly people requiring long-term care: a randomized cross-over study. Brain Sci. 9:54. doi: 10.3390/brainsci9030054

Nissim, E. (2001). Human Touch Massager. U.S. Patent No US2001014781. Washington, DC: U.S. Patent and Trademark Office.

Obokawa, Y., Solis, J., Ishii, H., Koga, H., Takanishi, A., and Katsumata, A. (2009). "Clinical massage therapy with the oral-rehabilitation robot in patients with temporomandibular joint disorders," in Proceedings of the 2009 9th International Conference on Information Technology and Applications in Biomedicine, Larcana, 1-4.

Ogai, R., Yamane, M., Matsumoto, T., and Kosaka, M. (2008). Effects of petrissage massage on fatigue and exercise performance following intensive cycle pedaling. Br. J. Sports Med 42, 834-838. doi: 10.1136/bjsm.2007.044396

Okamoto, T., Masuhara, M., and Ikuta, K. (2014). Acute effects of self-myofascial release using a foam roller on arterial function. J. Strength Condition. Res. 28, 69-73. doi: 10.1519/jsc.0b013e31829480f5

Oranchuk, D. J., Flattery, M. R., and Robinson, T. L. (2019). Superficial heat administration and foam rolling increase hamstring flexibility acutely; with amplifying effects. Phys. Ther. Sport 40, 213-217. doi: 10.1016/j.ptsp.2019. 10.004

Patel, D. G., Vyas, N. J., and Sheth, M. S. (2016). Immediate effect of application of bilateral self myo-fascial release on the plantar surface of the foot on hamstring and lumbar spine flexibility: a quasi experimental study. Int. J. Ther. Appl. 32, 94-99. doi: 10.20530/IJTA_32_94-99

Pathania, T., and Muragod, A. R. (2019). Comparative effect of foam roller and M2T blade on hamstring flexibility in elderly population: a randomized control trial. Indian J. Health Sci. Biomed. Res. 12:160. doi: 10.4103/kleuhsj.kleuhsj_ 118_18

Patole, S., Sayyad, S., and Palekar, T. J. (2019). To compare the effect of myofascial release technique versus foam rolling on hamstring spasticity in spastic Diplegia: pilot study. Int. J. Yoga Physiother. Phys. Educ. 4, 65-70.

Paz, G., Maia, M., Santana, H., Silva, J., and Lima, V. (2017). Electromyographic analysis of muscles activation during sit-and-reach test adopting self-myofascial release with foam rolling versus traditional warm. J. Athlet. Enhance. 4, 26-28. doi: 10.4172/2324-9080.1000248

Peacock, C. A., Krein, D. D., Antonio, J., Sanders, G. J., Silver, T. A., and Colas, M. (2015). Comparing acute bouts of sagittal plane progression foam rolling vs. Frontal plane progression foam rolling. J. Strength Condition. Res. 29:23102315. doi: 10.1519/jsc.0000000000000867

Peacock, C. A., Krein, D. D., Silver, T. A., Sanders, G. J., and Von Carlowitz, K.P. A. (2014). An acute bout of self-myofascial release in the form of foam rolling improves performance testing. Int. J. Exerc. Sci. 7:202.

Pearcey, G. E. P., Bradbury-Squires, D. J., Kawamoto, J.-E., Drinkwater, E. J., Behm, D. G., and Button, D. C. (2015). Foam rolling for delayed-onset muscle soreness and recovery of dynamic performance measures. J. Athletic Train. 50, 5-13. doi: 10.4085/1062-6050-50.1.01

Peng, C.-C., Hwang, T.-S., Lin, C.-J., Wu, Y.-T., Chang, C.-Y., and Huang, J.-B. (2010). "Development of intelligent massage manipulator and reconstruction of 
massage process path using image processing technique," in Proceedings of the 2010 IEEE Conference on Robotics, Automation and Mechatronics, Singapore, 551-556. doi: 10.1109/RAMECH.2010.5513135

Petrescu, R. V., Aversa, R., Apicella, A., and Petrescu, F. I. (2016). Future medicine services robotics. Am. J. Eng. Appl. Sci. 9, 1062-1087. doi: 10.3844/ajeassp.2016. 1062.1087

Phillips, J., Diggin, D., King, D. L., and Sforzo, G. A. (2018). Effect of varying self-myofascial eelease duration on subsequent athletic performance. J. Strength Condition. Res. [Epub ahead of Print],

Pinar, S., Kaya, F., Bicer, B., Erzeybek, M., and Cotuk, H. (2012). Different recovery methods and muscle performance after exhausting exercise: comparison of the effects of electrical muscle stimulation and massage. Biol. Sport 29, 269-275. doi: 10.5604/20831862.1019664

Poppendieck, W., Wegmann, M., Ferrauti, A., Kellmann, M., Pfeiffer, M., and Meyer, T. (2016). Massage and performance recovery: a meta-analytical review. Sports Med. 46, 183-204. doi: 10.1007/s40279-015-0420-x

Qiu, C., Zhang, Y., and Kai, L. (2019). Massage apparatus. https://worldwide. espacenet.com/publicationDetails/biblio?FT $=$ Danddate $=20190411$ andDB $=$ andlocale $=f r \_E P a n d C C=W O$ and $N R=2019070198 A$ 1 and $K C=A$ land $N D=1$.

Rapaport, M. H., Schettler, P., and Bresee, C. (2010). A preliminary study of the effects of a single session of swedish massage on hypothalamic-pituitaryadrenal and immune function in normal individuals. J. Alternat. Compl. Med 16, 1079-1088. doi: 10.1089/acm.2009.0634

Rey, E., Padrón-Cabo, A., Costa, P. B., and Barcala-Furelos, R. (2017). The effects of foam rolling as a recovery tool in professional soccer players. J. Strength Condition. Res. 33, 2194-2201.

Richards, K. (1998). Effect of a back massage and relaxation intervention on sleep in critically ill patients. Am. J. Crit. Care 7, 288. doi: 10.4037/ajcc1998.7.4.288

Rinder, A. N., and Sutherland, C. J. (1995). An investigation of the effects of massage on quadriceps performance after exercise fatigue. Compl. Ther. Nurs. Midwif. 1, 99-102. doi: 10.1016/S1353-6117(05)80048-4

Rivera, M., Eberman, L., Games, K., and Powden, C. J. (2019). Comparison of myofascial release techniques on pectoralis minor length, glenohumeral total arc of motion, and skin temperature: a pilot study. J. Sport Rehabil. 24, 1-5. doi: 10.1123/jsr.2018-0130

Robertson, A., Watt, J. M., and Galloway, S. D. R. (2004). Effects of leg massage on recovery from high intensity cycling exercise. Br. J. Sports Med. 38:173. doi: $10.1136 /$ bjsm.2002.003186

Romero-Moraleda, B., González-García, J., Cuéllar-Rayo, Á, BalsalobreFernández, C., Muñoz-García, D., and Morencos, E. (2019). Effects of vibration and non-vibration foam rolling on recovery after exercise with induced muscle damage. J. Sports Sci. Med. 18, 172-180.

Romero-Moraleda, B., La Touche, R., Lerma-Lara, S., Ferrer-Peña, R., Paredes, V., Peinado, A. B., et al. (2017). Neurodynamic mobilization and foam rolling improved delayed-onset muscle soreness in a healthy adult population: a randomized controlled clinical trial. PeerJ 5:18. doi: 10.7717/peerj. 3908

Rossettini, G., Rondoni, A., Schiavetti, I., Tezza, S., and Testa, M. (2016). Prevalence and risk factors of thumb pain in Italian manual therapists: an observational cross-sectional study. Work 54, 159-169.

Sağiroğlu, Ý (2017). Acute effect of applied local vibration during foam roller exercices on lower extremety explosive strength and flexibility performance. Eur. J. Phys. Educ. Sport Sci. 3, 20-30. doi: 10.5281/zenodo.89696

Saitou, K., Tokunaga, M., Yoshino, D., Sakitani, N., Maekawa, T., Ryu, Y., et al. (2018). Local cyclical compression modulates macrophage function in situ and alleviates immobilization-induced muscle atrophy. Clin. Sci. 132, 2147-2161. doi: 10.1042/CS20180432

Sakitani, N., Maekawa, T., Saitou, K., Suzuki, K., Murase, S., Tokunaga, M., et al. (2019). Application of consistent massage-like perturbations on mouse calves and monitoring the resulting intramuscular pressure changes. JoVE 151:e59475. doi: $10.3791 / 59475$

Schleip, R. (2003b). Fascial plasticity - a new neurobiological explanation Part 2. J. Bodywork Mov. Ther. 7, 104-116. doi: 10.1016/S1360-8592(02)00076-1

Schleip, R. (2003a). Fascial plasticity - a new neurobiological explanation: Part 1. J. Bodywork Mov. Ther. 7, 11-19. doi: 10.1016/S1360-8592(02)00067-0

Schroeder, A. N., and Best, T. M. (2015). Is self myofascial release an effective preexercise and recovery strategy? A literature review. Curr. Sports Med. Rep. 14, 200-208. doi: 10.1249/jsr.0000000000000148
Schroeder, J., Renk, V., Braumann, K.-M., and Hollander, K. (2017). Acute foam rolling effects on contractile properties of the m. Biceps femoris. German J. Exerc. Sport Res. 47, 294-300. doi: 10.1007/s12662-017-0467-y

Sharp, V. (2012). A Comparative Study Between Self Myofascial Release and Emmett Technique Effectiveness in the Management of fascial (iliotibial band) Tightness. Queen University Dissertation. Belfast: Stranmillis University College.

Sharpe, P. A., Williams, H. G., Granner, M. L., and Hussey, J. R. (2007). A randomised study of the effects of massage therapy compared to guided relaxation on well-being and stress perception among older adults. Compl. Ther. Med. 15, 157-163. doi: 10.1016/j.ctim.2007.01.004

Škarabot, J., Beardsley, C., and Štirn, I. (2015). Comparing the effect of selfmyofascial release with static stretching on ankle range-of-motion in adolescent athletes. Int. J. Sports Phys. Ther. 10, 203-212.

Skinner, B., Moss, R., and Hammond, L. (2020). A systematic review and metaanalysis of the effects of foam rolling on range of motion, recovery and markers of athletic performance. J. Bodywork Mov. Ther. 24, 105-122. doi: 10.1016/j. jbmt.2020.01.007

Smith, J. C., Washell, B. R., Aini, M. F., Brown, S., and Hall, M. C. (2019). Effects of static stretching and foam rolling on ankle dorsiflexion range of motion. Med. Sci. Sports Exerc. 51, 1752-1758. doi: 10.1249/mss.000000000000 1964

Smith, L., Keating, M. N., Holbert, D., Spratt, D. J., McCammon, M. R., Smith, S. S., et al. (1994). The effects of athletic massage on delayed onset muscle soreness, creatine kinase, and neutrophil count: a preliminary report. J. Orthop. Sports Phys. Ther. 19, 93-99. doi: 10.2519/jospt.1994.19.2.93

Solis, J., Obokawa, Y., Ishii, H., Koga, H., Takanishi, A., and Katsumata, A. (2009). "Development of oral rehabilitation robot WAO-1R designed to provide various massage techniques," in Proceedings of the IEEE International Conference on Rehabilitation Robotics, (Kyoto: IEEE), 457-462.

Somers, K., Aune, D., Horten, A., Kim, J., and Rogers, J. (2019). Acute effects of gastrocnemius/soleus self-myofascial release versus dynamic stretching on closed-chain dorsiflexion. J. Sport Rehabil. 29, 1-28. doi: 10.1123/jsr.20180199

Standley, R. A., Miller, M. G., and Binkley, H. (2010). Massage's effect on injury, recovery, and performance: a review of techniques and treatment parameters. StrengthCondition. J. 32, 64-67. doi: 10.1519/ssc.0b013e3181c33918

Stroiney, D. A., Mokris, R. L., Hanna, G. R., and Ranney, J. D. (2020). Examination of self-myofascial release vs. Instrument-assisted soft-Ttssue mobilization techniques on vertical and horizontal power in recreational athletes. J. Strength Condition. Res. 34, 79-88. doi: 10.1519/JSC.0000000000002628

Su, H., Chang, N.-J., Wu, W.-L., Guo, L.-Y., and Chu, I.-H. (2017). Acute effects of foam rolling, static stretching, and dynamic stretching during warm-ups on muscular flexibility and strength in young adults. J. Sport Rehabil. 26, 469-477.

Sullivan, K. M., Silvey, D. B., Button, D. C., and Behm, D. G. (2013). Rollermassager application to the hamstrings increases sit-and-reach range of motion within five to ten seconds without performance impairment. Int. J. Sports Phys. Ther. 8, 228-236.

Suzuki, M., Tatsumi, A., Otsuka, T., Kikuchi, K., Mizuta, A., Makino, K., et al. (2010). Physical and psychological effects of 6-week tactile massage on elderly patients with severe dementia. Am. J. Alzheimers Dis. Other Dement. 25, 680-686. doi: 10.1177/1533317510386215

Takanishi, A., Katsumata, A., Koga, H., Ishii, H., Solis, J., and Obokawa, Y. (2009). Massage Robot and Control Program Thereof. U.S. Patent No WO2009118933. Washington, DC: U.S. Patent and Trademark Office.

Takanishi, A., Katsumata, A., Usuda, Y., Koga, H., Matsuno, M., Ogura, Y., et al. (2008). Massage Robot, Control Program Therefor, and Robot for Specifying Portion of Human Body. U.S. Patent No WO2008041457. Washington, DC: U.S. Patent and Trademark Office.

Thistlethwaite, J., Vonderhaar, R., Hockenberry, K., Rindler, L., Cayot, T., and Nelson, B. (2016). The effects of foam-rolling on femoral endothelial function. Med. Sci. Sports Exerc. 48:1070. doi: 10.1249/01.mss.0000488219.26597.5b

Thomson, D., Gupta, A., Arundell, J., and Crosbie, J. (2015). Deep soft-tissue massage applied to healthy calf muscle has no effect on passive mechanical properties: A randomized, single-blind, cross-over study. BMC Sports Sci. Med. Rehabil. 7:21. doi: 10.1186/s13102-015-0015-8

Tiidus, P., and Shoemaker, J. (1995). Effleurage massage, muscle blood flow and long-term post-exercise strength recovery. Int. J. Sports Med. 16, 478-483. doi: $10.1055 /$ s-2007-973041 
Vigotsky, A. D., and Bruhns, R. P. (2015). The role of descending modulation in manual therapy and its analgesic implications: a narrative review. Pain Res. Treat. 2015, 1-11. doi: 10.1155/2015/292805

Vigotsky, A. D., Lehman, G. J., Contreras, B., Beardsley, C., Chung, B., and Feser, E. H. (2015). Acute effects of anterior thigh foam rolling on hip angle, knee angle, and rectus femoris length in the modified Thomas test. PeerJ 3:e1281. doi: $10.7717 /$ peerj. 1281

Viitasalo, J. T., Niemelä, K., Kaappola, R., Korjus, T., Levola, M., Mononen, H. V., et al. (1995). Warm underwater water-jet massage improves recovery from intense physical exercise. Eur. J. Appl. Physiol. Occupat. Physiol. 71, 431-438. doi: 10.1007/BF00635877

Visconti, L., Capra, G., Carta, G., Forni, C., and Janin, D. (2015). Effect of massage on DOMS in ultramarathon runners: a pilot study. J. Bodywork Mov. Ther. 19, 458-463. doi: 10.1016/j.jbmt.2014.11.008

Weerapong, P., Hume, P. A., and Kolt, G. S. (2005). The mechanisms of massage and effects on performance, muscle recovery and injury prevention. Sports Med. 35, 235-256. doi: 10.2165/00007256-200535030-00004

White, G. E., West, S. L., Caterini, J. E., Battista, A. P. D., Rhind, S. G., and Wells, G. D. (2020). Massage therapy modulates inflammatory mediators following sprint exercise in healthy male athletes. J. Funct. Morphol. Kinesiol. 5:9. doi: 10.3390/jfmk5010009

Wiewelhove, T., Döweling, A., Schneider, C., Hottenrott, L., Meyer, T., Kellmann, M., et al. (2019). A meta-analysis of the effects of foam rolling on performance and recovery. Front. Physiol. 10:376. doi: 10.3389/fphys.2019.00376

Willems, M. E., Hale, T., and Wilkinson, C. S. (2009). Effect of manual massage on muscle-specific soreness and single leg jump performance after downhill treadmill walking. Med. Sport. 13, 61-66. doi: 10.2478/v10036-009-0011-8

Williams, W., and Selkow, N. M. (2019). Self-myofascial release of the superficial back line improves sit-and-reach distance. J. Sport Rehabil. 1, 1-5.

Wiltshire, E. V., Poitras, V., Pak, M., Hong, T., Rayner, J., and Tschakovsky, M. E. (2010). Massage impairs postexercise muscle blood flow and" lactic acide removal. Med. Sci. Sports Exerc. 42, 1062-1071.
Xiaoqin, Y., and Yonggen, X. (2010). "Design and simulation of Chinese massage robot based on parallel mechanism," in Proceedings of the 2010 International Conference on Mechanic Automation and Control Engineering, 2512-2515. doi: 10.1109/MACE.2010.5535326

Yang, J., Chen, S., Hsieh, C.-L., and Lin, J. (2012). Effects and predictors of shoulder muscle massage for patients with posterior shoulder tightness. BMC Musculoskelet. Disord. 13:46. doi: 10.1186/1471-2474$13-46$

Ye, X., Killen, B. S., Zelizney, K. L., Miller, W. M., and Jeon, S. (2019). Unilateral hamstring foam rolling does not impair strength but the rate of force development of the contralateral muscle. PeerJ 7:e7028. doi: 10.7717/peerj. 7028

Zainuddin, Z., Newton, M., Sacco, P., and Nosaka, K. (2005). Effects of massage on delayed-onset muscle soreness, swelling, and recovery of muscle function. J. Athlet. Train. 40, 174-180.

Zelikovski, A., Kaye, C. L., Fink, G., Spitzer, S. A., and Shapiro, Y. (1993). The effects of the modified intermittent sequential pneumatic device (MISPD) on exercise performance following an exhaustive exercise bout. Br. J. Sports Med. 27:255. doi: 10.1136/bjsm.27.4.255 doi: 10.1136/bjsm.27.4.255

Conflict of Interest: CE was employed by the company Capsix Robotics.

The remaining authors declare that the research was conducted in the absence of any commercial or financial relationships that could be construed as a potential conflict of interest.

Copyright (C) 2020 Kerautret, Di Rienzo, Eyssautier and Guillot. This is an open-access article distributed under the terms of the Creative Commons Attribution License (CC BY). The use, distribution or reproduction in other forums is permitted, provided the original author(s) and the copyright owner(s) are credited and that the original publication in this journal is cited, in accordance with accepted academic practice. No use, distribution or reproduction is permitted which does not comply with these terms. 